\title{
ADVANCED DRECT LIQUEFACTION CONCEPTS PROGRAM PHASE II
}

\author{
RUN ALC-1 COAL CLEANING \\ AND RECYCLE SOLVENT TREATMENT
}

Final Report

Prepared for

The U.S. Department of Energy

under Contract No.

DE-AC22-1PC91040

Prepared by

J. L. Hu and L. K. Lee

Submitted by

University of Kentucky

(Center of Applied Energy Research)

CONSOL Inc.

LDP Associates

Hydrocarbon Technologies, Inc.

Sandia National Laboratories

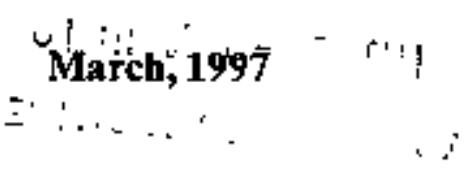




\title{
ACKNOWLEDGMENT
}

This program is funded by the U.S. Department of Energy under Contract No. DE-AC22+ 91PC91040. The project team responsible for Run ALC-1 consisted of the following key members:

\author{
F.J. Derbystire, E.N. Givens and R. Aaderson \\ University of Kentucky, Center for Applied Energy Research \\ G.R. Robbins, RA. Winschel and F.P. Burke \\ CONSOL Inc., Research and Development
}

\author{
M.P. Peluse \\ LDP Associates
}

J.L. Fu and L.K, Lee

Hydrocarbon Technologies, Inc.

\section{J.E. Miller and H.P. Stephens \\ Sandia National Laboratory}

In addition, engineers, chemists, laboratory technicians and operating staff from several individual organizations also made significant contributions towards the success of this run. 


\section{TABLE OF CONTENT}

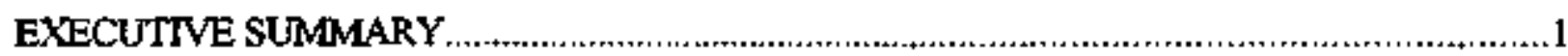

BACKGROUND,

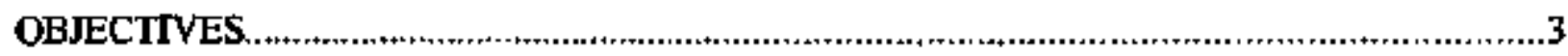

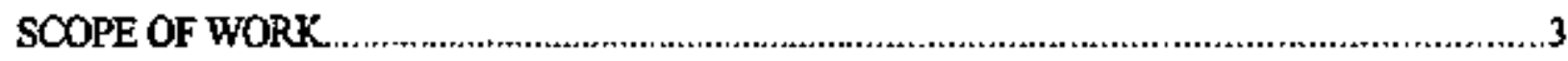

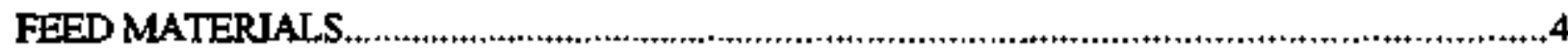

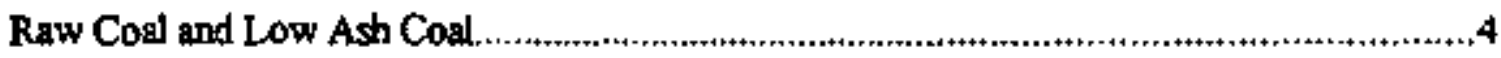

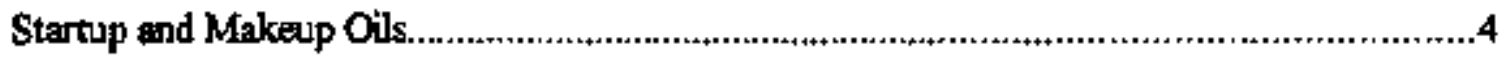

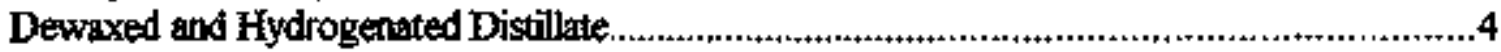

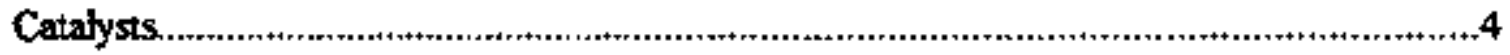

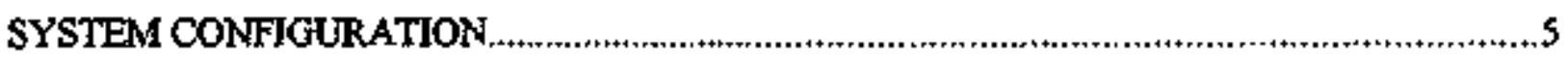

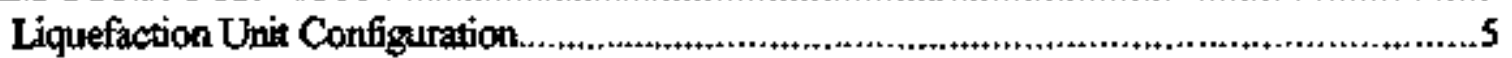

Solvent Preparation and Solid Rejection....................................................................... 6

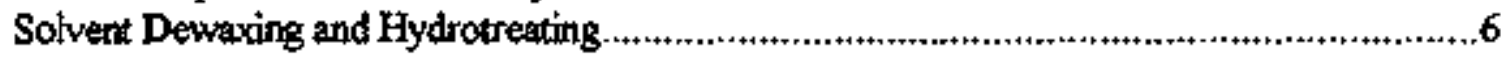

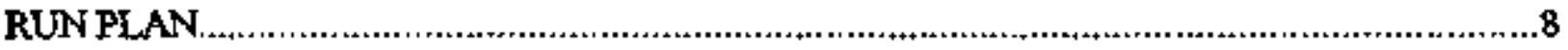

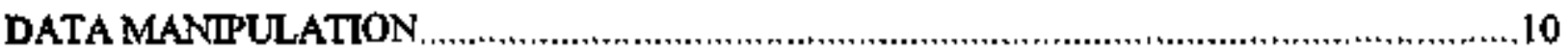

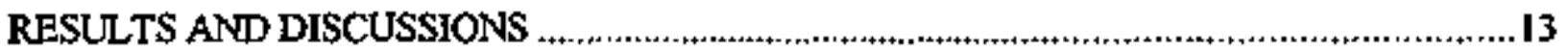

Overall Process Performarce.......................................................................................... 13

Two Stage Performance .................................................................................................

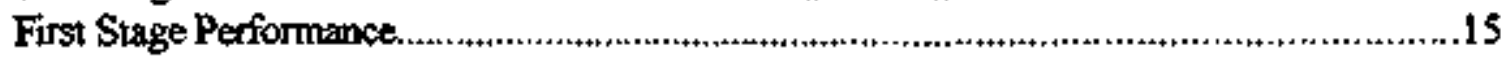

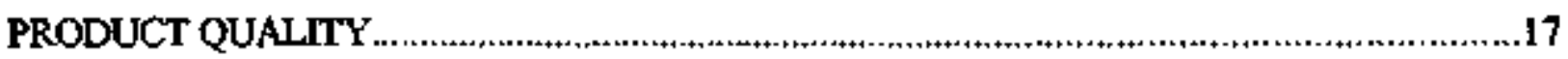

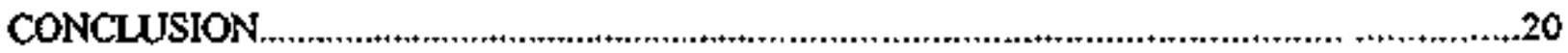

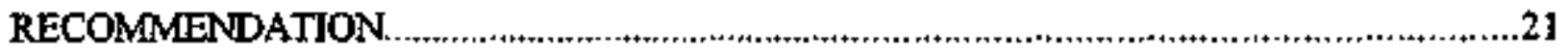

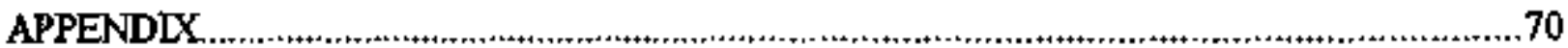

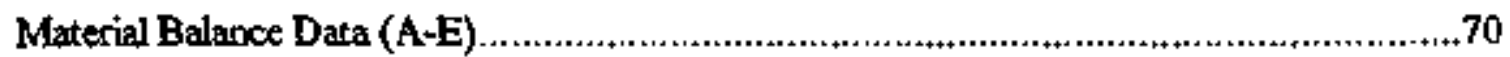

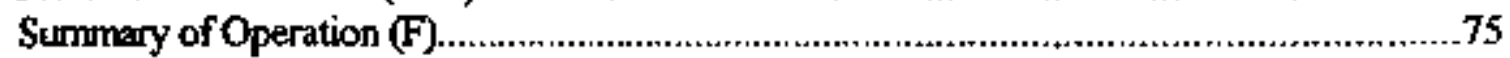

Sirmulated Distillarion of First and Second Stage Overteads (G) .................................81

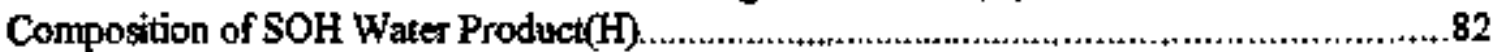

Impact of Cabon Loss in SOH Water on Distillate Yield (T) .......................................83

Daily Analysis of Pressure Filter Cake and Recycle Solvents (J) ....................................\&4

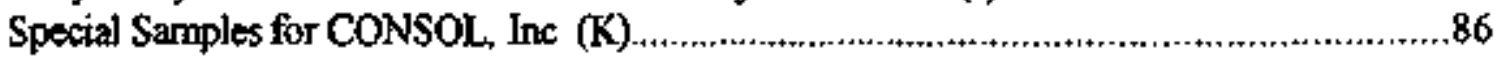




\section{LIST OF TABLES}

Table 1. Analysis of Feed : Black Thunder Mire Coal........................................................22

Table 2. Analytis of Agglomerating Oil..................................................................23

Table 3. Composition of Agglonerate Products..............................................................24

Table 4. Major Elemental Analysis of Ash in Oil-Agglomerated Coal.............................25

Table 5. Analysis of Start-up/Make-up Oil ..........................................................226

Table 6. Properties of Pre-prepared DW-HT VSOH

Table 7. ALC-1 Bench Run (227-94) Detailed Plan ......................................................28

Table 8. Daily Material Balance and Recycie Concentrations.........................................29

Table 9. Composition of Recycle Strearn..................................................................30

Table 10. Sumnay of Process Performance............................................................31

Table 11. First Stage Perfomance..............................................................................32

Table 12. Properties of Second Stage Separator Overtead................................................,33

Table 13. Properties of Pressure Filter Liquid and Vacuum Still Overhead ........................34

Table 14. Properties of Vacuum Still Bottons ..................................................................35

Table 15. Properties of Uarefined Wax Product.............................................................36

Table 16. Properties of Pressure Filter Cake...................................................................37

Table 17 Properties of Joluene Extracted Pressure Filter Cake............................................38

Table 18. Properties of First Stage Separator Overhead .....................................................39

Table 19. Properties of First Stage Sample Pressure Filter Liquid..........................................40

Tabje 20. Property of Firs Stage Sarnple-Pressure Filter Cake........................................41

Table 21. Properties of Dewaxed and Hydrotreated Solvent............................................42

Tables 22-28. Analysis of TBP Fractions (Conditions 1-5) ...................................................43

Table 29. Phenolic Content of Separator Overtead .........................................................50

Table 30. Characterization of Hydrotreater Catalyst .......................................................5]

Tabje 31. Comparisor of Run ALC-1 and CMSL-9.................................................

Table 32. Run ALC-1 Operations-Status-Classification Chronology ...................................53

Table 33. On- line Time and Down Time For Run ALC-1 ..............................................53 


\section{LIST OF FIGURES}

Figure 1. Simplified Schematic of HTI's Bench Unit.......................................................54

Figure 2. Downstream Product Flow Scheme-Condition 1..............................................55

Figure 3. Downstream Product Flow Scheme-Condition 2............................................56

Figure 4. Downstream Product Flow Scherne-Conditions 3\&4

Figure 5. Downstream Product Flow Schenxe-Condition 5.............................................58

Figure 6. Simplified Sctematic of HTI's Ketone Dewaxing Unit....................................59

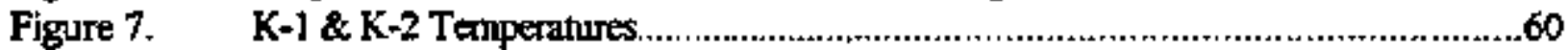

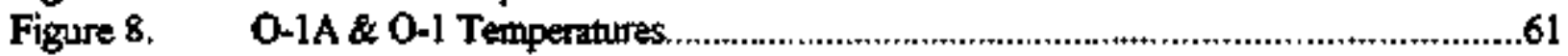

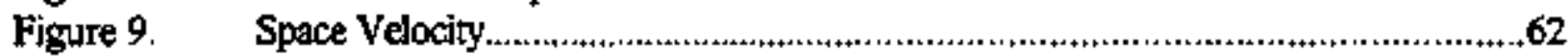

Figure 10. Daily Material Balance........................................................................63

Figure 11. C4524 $\mathrm{C}$ Distillate Yield \& 524 ${ }^{\circ} \mathrm{C}+$ Yield .......................................................64

Figure 12. C4-\$24 $4^{\circ} \mathrm{C}$ Distillate Fraction Yield..................................................................65

Figure 13. Hydrogen Consumption \& Light CI-C3 Gas Yield............................................66

Figure 14. Hydrogen Efficiency \& C1-C3 Gas Selectivity...................................................67

Figure 15. Quality of 2nd Stage SOH Distilates ....................................................................68

Figure 16. Distillate Fraction Selectivity................................................................69 


\section{EXECUTTVE SUMMARY}

The DOE Advanced Direct Liquefaction Concepts Progran was initiated in 1991 with the objective of promoting the development of new and energing technology that has potential to reduce the cost of producing liquid fuels by direct coal liquefaction. The laboratory research program (P'oase I) was completed in 1995 by CAER, CONSOL, Sandia and LDP Associates. A new three year bench scale test program was subsequently awarded in October 1995 to further develop several promising concepts derived from the laboratory program. The new progran is composed of four continuous flow tests using a $2 \mathrm{Kg} / \mathrm{h}$ bench scale unit at Hydrocarbon Technologies, Inc. (HT). The overall objectives of the first two tests ane:

ALC-1 Coal Cleaning and Recycie Solvent Treatment AlC-2 Advanced Slunry Catalysts

The first test ALC-1 was conducted between April 19 and May 14, 1996 and consisted of five test conditions over a period of 25 days. The feed coal was Wyoming sub-bituminous coal from Black Thunder Mine. Ash content of the feed coal was reduced from 5.5 to $2.3 \%$ ( $\mathrm{SO}_{3}$-free basis) by CONSOL using an oil agglomeration technique. The recycle solvent used in the last process condition was dewaxed and hydrogenated in a fixed bed reactor as an approach to quality improvement.

There were four main technical objectives for Run ALC-I:

1. To provide a baseline operating period with raw Black Thunder coal.

2. To demonstrate liquefaction of low ash coal produced by a low $\mathrm{pH}$ oil agglomeration texhrique.

3. To evaluate the impact of improving solvent quality by dewaxing and hydrotreating.

4. To operate under conditions leading to extinction of $343^{\circ} \mathrm{C}^{+}$material.

Improvements in liquefaction process performance were measured relative to previous results from Wilsonville pilot plant and HTI bench scale runs.

Run ALC-I employed two slurry liquefaction reactors in series, an interstage separator, and a directcoupled hydrotreater. An additional fixed bed reactor was used to hydrotreat the distillable $\left(-524^{\circ} \mathrm{C}\right)$ portion of the dewaxed recycle solvent in Condition 5 . Several recycle liqujd and solid separation schemes were adopted throughout the run to minimize the lag time required to produce the desired recycle solvent and solids. The target total recycle and recycle solid to fresh feed ratio was 1.60 and 0.2 , respectively. The removal of solids was achieved by pressure filtration. In Condition 1 , in order to ensure a consistent oil content on the recycle solid, all pressure filtation cakes were toluene extracted. However, this caused considerable delay in establishing a steady state operation. Starting from Conotition 2 onward, the lag time in the solid/liquid operation was significantly reduced by extracting only the net amount of cake that would be rejected. The portion of solid for recycle did not go through toluene extraction.

Two catalyst precursors were evaluated: Molyvan A and a HTl proprietary iron based gel. The 
equivalent Mo and Fe content was 70-100 ppm and 0.7-1.0 w\% of moisture-free coal, respectively. The precursors were premixed with the feed coal and recycle solvent before injecting them into a coiled preteater. Black Thunder coal used in this rus was supplied by HTI and was the same batch that was employed in HTI's POC-O2 nn. The low ast oil agglomerated coal prepared by CONSOL, comtained $3.3 \mathrm{w} \%$ ash ( $\mathrm{mf}, \mathrm{SO}_{3}$-free basis), which was $40 \mathrm{w} \%$ lower than that of the raw coal.

The $2 S$ day slurty catalyst operation went smoothly with no major mechanical or process problems. Excellent coal conversion of above $95 \mathrm{w} \%$ was obtained under all conditions. There were no handing problems with the agglomerated coal, it redispersed well in the recycle solvent. Also, oil agglomerated coal was more reactive with $3 \mathrm{w} \%$ higher coal corversion and increased distillate yield of $2-3$ w\% (maf coal basis).

Extinction of $343^{\circ} \mathrm{C}+$ material was not achieved under the process conditions evaluated. However, at the low space velocity of $400 \mathrm{~kg} / \mathrm{h} / \mathrm{m}^{3}$ reactor, the $454^{\circ} \mathrm{C}+$ material was close to extinction (only $0.8 \mathrm{~W} \% \mathrm{maf}$ cos was produced). This fraction varied between 5.5 to $16.9 \mathrm{~W} \%$ in other less severe process conditions.

The dewaxing and hydrotreating operation caused long delays in preparing distillate recycle solvent. Even at the end of Sth day of Condition S, a solvent of steady quality was not obtained. For this reason, no definitive conclusion can be drawn regarding the inpact of the dewaxing/hydrotreating operation on the process performance.

In view of the importance of achieving steady state operation conditions, it is recommended that the liquid/solid separation and solvent processing operation be simplified to shorten the turnaround time in future nuns. Also, the practicality of achieving $343^{\circ} \mathrm{C}+$ extinction should be examined and compared to high throughput but with some production of $454^{\circ} \mathrm{C}+$ material. 


\section{BACKGROUND}

The Advanced Concepts Program was initiated by the Departnent of Energy in 1991 to promote the development of new and emerging technologies that have potential, alone or in combination, to significantiy reduce the cost of producing liquid fuels by direct coal liquefaction. Among other efforts, the advanced two-stage liquefaction technologies that were developed at Wilsonville over the past 10 years and by Hydrocarbon Technologies, Inc. have contributed significantly towards decreasing the cost of producing gasoline from coal. The approach has been to develop a long term strategy, in which promising liquefaction concepts, that have been identified mainly through fundamental studies, are subject to technical and economic evaluation on an increasing scale of experimentation for integration into a viable process configuration. The first phase of this strategy involved the laboratory-scale evaluation of selected concepts. The second phase will be concemed with evaluating the most promising concepts from Phase I in a continuous liquefaction unit. The outcomes of Phase if will be to ascertain the effects of scale-up on the projected improvements in liquefaction performanoe, and to provide a higher degree of confidence in the results and in the technical and economic assessinents and forecasts.

\section{OBJECTIVE}

The objectives of Run ALC-1 were to demonstrate the liquefaction performance benefits of cleaning Black Thunder Mine coal, and the concept of solvent improvement through dewaxing and hydrogenation of the distillate portion of the recycle solvent. The coal cleaning method used was oil agglomeration at low pH. Expected benefits of coal cleaning inclusde: higher coal conversion and higher distillate yield due to decreased organic rejection, and decreased dispersed catalyst requirement due to increased dispersed catalyst recycle. Potential benefits of solvept dewaxing and hydrotreating are improved coal conversion and improved resid conversion due to solvent quality improvements, lower gas make and decreased hydrogen corsurption resulting from lower paraffin cracking. recovery of a valuable wax byproduct, and possible reduced severity resulting from the need for less cracking.

\section{SCOPE OF WORK}

The ALC-1 nun plan included five nun conditions that were selected to meet the technical objectives specified above. Interstage product separation was employed to reduce the yield of light gases $\left(\mathrm{C}_{1}\right.$ $-\mathrm{C}_{3}$ ) and to increase the residence time of $343^{\circ} \mathrm{C}+$ fraction in the second reactor. In-line hydrotreating was conducted to improve product quality. Presstre filtration was used as the solid rejection device, allowing enough flexibility to recycle a high concentration of resid while maintaining a low resid-tosolio ratio in the rejected PFC. A vacuum still was also employed to separate VSB from PFL. The first condition was designed as a baseline operation and was carried out at a space velocity of 670 $\mathrm{kg} / \mathrm{h} / \mathrm{m}^{3}$. Starting from Period 8 of Condition 2, extinction recycle of $343^{\circ} \mathrm{C}+\mathrm{VSB}$ was attempted in order to maximize distillate yield. During Conditions 2 through 4 , raw coal was replaced by oil agglomerated coal and space velocity, catalyst concentration, and ash content in the recycle stream were adjusted to improve distillate yield. Condition 5 was designed to stady the effect of solvent dewaxing and hydrotseating on the process performance. 


\section{FEED MATERIALS}

\section{Raw and Low Ash Coal}

The coal for this nun was Wyoming sub-bituminous Black Thunder Mine. The pulverized coal was originally prepared by Empire Coke Co. for HTl's Run POC-02. A typical analysis of this bateh of coal is given in Table 1. The moisture and ash content was $10.0 \mathrm{w} \%$ and $6.0 \mathrm{w} \%$ on dry basis, respectively. Its low sulfur content, $0.35 \mathrm{w} \%$, was typical of Western sub-bitiminious coal.

The low ash coal sample $(590 \mathrm{Kg}$ ) was prepared ny CONSOL Inc. using a low pH oil agglomeration tochnique. The bridging oil was a heavy recycle distillate (V-1074) from the Wilsonville Pilot Plant end-of-rum inventory from Run 263. Its analysis is shown in Table 2. Over $32.9 \mathrm{w} \%$ of this heavy distillate boiled above $454^{\circ} \mathrm{C}$ and the hydrogen content was $9.16 \mathrm{w} \%$. Detijls of the preparation procedure can be found in a recent paper by $\mathrm{CONSOL}$. As a percentage of the whole agglomerates $(590 \mathrm{Kg})$, the agglomerates were composed of $7.6 \mathrm{w} \%$ moisture, $23.5 \mathrm{w} \%$ bridging oil, $2.3 \mathrm{w} \% \mathrm{SO}_{3}$. free ash and $66.7 \mathrm{w} \%$ maf coal. Composition of each individual batch is presented in Table 3 . At low $\mathrm{pH}$ there was significant reduction in the sodjum, calcium and magnesiom content of the ash, as shown in Table 4.

\section{Startup and Maketp Oil}

L-814, which was the end-of-ron makeup oil in Tank \#4 from HTY's POC-02 run, was used as startup oil to bring the unit to near operating conditions and was the initial vehicle oil for slurrying the coal for Condition 1. As process derived solvent was avaliable, L-814 was phased out gradually. L-814 contained a unknown proportion of coal and petroleum (hydrotreated FCC decant oil) derived materials. It has a low API gravity of $0.4^{\circ}$ and over $40.5 \mathrm{w} \%$ of $454^{\circ} \mathrm{C}^{+}$materials (Tabie 5). Apart from the first couple of days, L-814 was not required in the subsequent periods.

\section{Dewayed and Hydrogenated Distillate}

About $200 \mathrm{~kg}$ of DW-HT VSOH was prepared prior to the Run ALC-1. The starting material VSOH was obtained from previous bench runs (CMSL 9-11, PB01 and 02). Their analysis is shown in Table 6.

\section{Catalysts}

A dispersed dual slunry catalyst systern composed of Molyvan A and HTI iron based gel catalyst was used in the entive run. On a dry coal feed basis, molybdenum and iron concentrations were 70-100 ppm and 0.7-1.0 w\%, respectively. Sulfur additive was incorporated into each stage to provide an equivalent of $3.0 \mathrm{w} \%$ of sulfur in each of the reactor.

The two fixed bed hydrotreaters were packed with Criteron $\mathrm{C}-411$ trilobe catalyst. 


\section{SYSTEM CONFIGURATION}

HTI's two-stage bench scale unit was reconfigurated to meet the specific requirements of ALC-1.

The major components for ALC-1 are:

- a 31 , 8 liter feed tank (P-2) and two parallel charge pumps (J-1 \& I-2)

- a $1330 \mathrm{cc}$ coiled preheater

- a $2000 \mathrm{cc}$ first stage backmixed reactor (K-1)

- a first stage product recovery system (0-1A, Hot Separator, 0-2A Cold Separator)

- a 2000 ce second stage backmixed reactor (K-2)

- a second stage Hot Sepafator (0-1)

- a $500 \mathrm{cc}$ fixed-bed direct coupled hydrotreater

- a second stage product recovery system:

- O-2 Cold Separator

- O-3 Hot Separator Bottom Flasher

$-12^{*}$ pressure filter

- vacuum stills

- acetone dewaxing and solvent recovery unit

- filter cake toluene extraction unit

- Two 250 cc fixed-bed off-line solvent hydrogentaion unit

\section{Ligufaction Unit (HTI Unit 227) Configaration}

A schematic flow diagram is depicted in Figure 1. Coal or agglomerated coal was premixed with catalysts, sulfur anditive, recycle solvent and solids in a small batch prior to charging to the Feed Tank (P-2). Joined by feed hydrogen, the gasffeed slurny stream passed through a short residence time coiled preheater ( 5 minutes). Temperature of the feed mixture was raised to $140^{\circ} \mathrm{C}$ below the first stage reactor temperature. The preheated feed inixture enetered the bottom of the first reactor and exited through the top. An internal circulating pump returned a portion of the reactor slurry to the bottom of the reactor providing the backmixing action. The first stage light reaction product was cooled and separated from the main sturry. This light product, along with other second stage nonhydrotreated products, were fed to the direct-coupled hydrotreater. The main slurry was firther liquefied in the second stage backmixed reactor.

The hot vapor products from the second stage liquefaction reactor were separated in the hot separator and fed directly into a fixed bed hydrotreater. The hydrotreater (K-3) was connected directely with the hot separator without pressure reduction. Hydrogen, $C_{1}-C_{3}$ hydrocarbons, heteroatom gasecus products, water and volatile liquid products from the overhead of the separator passed through a mixing phase trickled bed hydrotreater. The main function of the hydrotreater was to stabilize the hydrocarbon products and to reduce heteroatoms $(\mathrm{N}, \mathrm{S}$, and $\mathrm{O}$ ). The hydrotrerater was packed with $500 \mathrm{cc}$ Criterion $\mathrm{C}-4113 \mathrm{~mm}$ tribbe catalyst. Temperture of K-3 was controlled at $379^{\circ} \mathrm{C}$ throughout the entire num. 
In addition to the hot vapor from the separator, several other light product streams were also fed to the hydrotreater. These streams were first stage overheads (water-free), atmospheric flash from the hot separator bottoms, amospheric still overheads and all other unit knockouts. These materials were blended and injected using a single pump.

\section{Solvent Preparation and Solid Rejection}

The heavy tiquid/solid separation system consisted of the following components: Atroospheric Still, Pressure Filtration, Vacuum Still and Toluene Extraction unit.

The solid containing heavy product stream from the bottom of hot separator was flashed, then distilied in a packed atmospheric still. The topped product slurry was filtered undet elevated pressure and temperature. The solid-free liquid constituted the recycle solvent, while the oil-laden filter cake was further extracted with tolvene to reduce the amoumt of organic rejection.

The atmospheric still operation experienced bumping problems during the frst couple of days of the run. The packed bed was clogged with solids and became ineffective in providing the proper cut points. High boiling materials and possibly some unreacted coal ended up in the direct-coupled hydrotreater (K-3). The still was bypassed from Period 5 onward.

At the beginning of the run, all filter cake was extracted with toluene to control the oil content of the recycle solid and to minimize the amount of oil rejected with the solid residuals. However, the extraction and toluene recovering operation caused significant delay in establishing a stesdy state operation. Several improvements were subsequently implemented to shorten the recycle solvent and solid processing time. One of these improvements was to recycle the oil-laden filter cake without toluene extraction. Also, a light distilate cul from the vacuum still operation was used as a diluent to reduce the viscosity of the feed to the filter. The recycle solvent and solid recovery schemes used in the run are illustrated in Figures 2 through 5.

\section{Solvent Dewaxing and Hydrogenation System}

In Condition 5, the distillable portion of the recycle solvent was dewaxed using acetone at a reduced temperature of $-10^{\circ} \mathrm{C}$. The dewaxed solvent was subsequently hydrotreated to improve its hydrogen content. Dewaxing was performed in a batch mode, as shown in Figure 6. About $18 \mathrm{~kg}$ of $524^{\circ} \mathrm{C}$ cut from the vacuum still was charged to a mixing tank to which acetone, in a ratio of $3 / 1$ (acetone/feed), was added. The mixture was agitated for about 60 minutes minutes and then transfertes to a jacketed chilker. Terperature of the mixture was brought down to $-5^{\circ} \mathrm{C}$. Sufficient time $(120 \mathrm{~min})$ was allowed to ensure proper precipitation of the waxy material. The wax was recoved by using two filters ( 25 and 2 micron) connected in series. Acetone was separated from the dewaxed distiltate by flashing at atmospheric temperature.

The dewaxed distillate was then fed to a fixed-bed hydrotreater. The hydrotreater was made of 0.957 inch dianeter tube with a catalyst loading of $253 \propto$. The reactor tube was immersed in 
fluidized sand bath heater and was maintained at a temperature of $360^{\circ} \mathrm{C}$, with a system back pressure of $15 \mathrm{MPa}$. The feed rate was approximately $650 \mathrm{~g} / \mathrm{hr}$. Hydrogen was fed at a rate of 0.652 $\mathrm{m}^{3} / \mathrm{hr}$ in each reactor. Two reactors were used for hydrotreating. 


\section{RUN PLAN}

Run ALC-1 consisted of five process conditions extending over 25 periods(days). As shown in Table 7, Condition 1 (Petiods $\mathbf{l}-6$ ) was a baseline condition designed to compare with HTI's CMSL9 Condition 6, but using Molyvan A and HTI Fe gel catalyst, instead of HTI Fe powder catalyst. Temperatures of the major reaction vessels were held constant throughout the entire rum:

$\begin{array}{ll}\text { Preheater. } & 300^{\circ} \mathrm{C} \\ \text { 1st stage Reactor. } & 440^{\circ} \mathrm{C} \\ \text { 2nd stage Reactor: } & 450^{\circ} \mathrm{C} \\ \text { In-line Hydrotreater: } & 379^{\circ} \mathrm{C} \\ \text { 1st stage Hot Separator } & 332^{\circ} \mathrm{C} \\ \text { 2nd stage Hot Separator: } & 340^{\circ} \mathrm{C}\end{array}$

Also, with the exception of Condition S, the ratio of total recycle to moisture free coal was 1.60. When oil agglomerated coal was used, Conditions 2 through 4 , the bridging oil on the agglomerates was considered as recycle solvent. In eacb case, the amount of process derived solvent for recycling was reduced accordingly to maintain a recycle/feed ratio of 1.60 . Fresh molybdenum and iron contents were $100 \mathrm{ppm}$ and $1.0 \mathrm{~W} \%$ of mf coal. The $\mathrm{mf}$ coal space velocity was $670 \mathrm{~kg} / \mathrm{h} / \mathrm{mr}^{3}$ in each reactor. Solid recycle was achieved by recycling toluene-washed PFC. The recycle stream consisted of pressure filter liquid (PFL) and a portion of the toluene-extracted PFC. The vacurum still was not used for Condition 1 . The recycle strategy was to satisfy the recycle solid concentration ( 0.2 recycle to $\mathrm{mf}$ feed). Once this target was altained, the excess toluene washed PFC was rejected. The balance of the recycle consisted of PFL.

Due to the long cycle time (12 hours) for PFC extraction with toluene, the target recycle solid ratio was not achieved until the fourth day of operation. As a result, Condition 1 was extended by one period and completed after Period 6. Also, Condition 1 was not operated in the resid extinction mode. There was an excess of PFL ( approximately $18 \mathrm{~W} \% \mathrm{mf}$ coal), which was credited as product. Toward the end of Condition 1 , the PFC extraction time for recovering oil on the cake was shortened from 12 hours to 6 hours.

Starting from Condition 2 (Periods 7 to 13), the feed was switched from raw coal to a low ash , oil agglomerated caaj. Also, early in this condition, the recycle strategy, as well as the space velocity, was modified aiming at extineting the $343^{\circ} \mathrm{C}+$ material. Firstly, the space velocity was decreased from 670 to $560 \mathrm{~kg} \mathrm{mf} \mathrm{coal} / / 2 \mathrm{~m}^{3}$. Secondly, all PFL was sent to the vacuum still, and all the vacuum still bottoms(VSB) and enough of the vacuum still overhead (VSOH) were recycled as necessary to

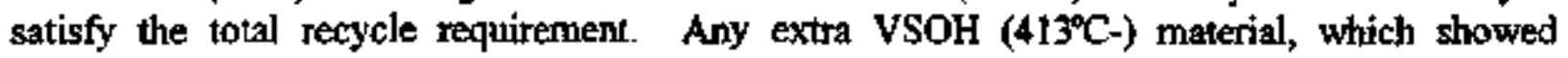
approximately equal amount to the distillate agglomerating oil, was collected as product.

In Condition 3 (Periods 14-17), the make-up catalyst rate was reduced by $30 \%$ relative to Conditions 1 and 2 , while other process parameters remained unchanged, In order to minimize the recycle of 
light material, a second vacuum still cut point of $343^{\circ} \mathrm{C}$ was implemented. The $343-423^{\circ} \mathrm{C}$ stream becarne the source of agglomerating oil equivalent and recycie distillate.

In Condition 4 (Periods 18-20), all process parameters were the same as in Condition 3, except that the space velocity was further reduced to $400 \mathrm{~kg} \mathrm{mf} \infty \mathrm{mal}^{2} / \mathrm{m}^{3}$, so that all $343^{\circ} \mathrm{C}+$ could be extincted.

In Condition 5 (Periods 21-25), the feed was switched back to raw Black Thunder coal. In order to reflect any possible process improvement as a result of the higher quality recycle solvent(dewaxing and hydrotreating), it was decided to keep the catalyst make-up rate at $70 \%$ of the Condition 1 value, and to set the space velocity at $480 \mathrm{~kg} \mathrm{mf} \mathrm{coal} / \mathrm{h} / \mathrm{m}^{3}$ reactor. The entire PFL stream was vacuum distilled at $524^{\circ} \mathrm{C}$ to produce $524^{\circ} \mathrm{C}$ - VSOH for dewaxing and hydrotreating. Waxes from the Ketone dewaxing unit was kept as a product stream. The dewaxed and hydrogenated VSOH was fractionated and the $343^{\circ} \mathrm{C}+$ portion was recycled. Due to the long turnaround time for dewaxing and hydrotreating operation, an initial batch of DW-HT distillate was prepared using Black Thunder coal-derived liquid from previous HTI bench nuss. This material constituted a large percentage of the recycle solvent during the early part of Condition 5 , and was gradually replaced by process produced DW-HT distillate in the last three days of Condition 5. 


\section{Feed Streams}

\section{DATA MANమIULTION}

The spread sheet program provides for $S$ fresh feed streams, 5 non-fresh feed streams and 10 product/recycle streams. Each stream type is handled differently in the calculations of yield. The 5 fresh feed streams ( normally coal, feed oil, waste plastic, etc.++) have not yet passed through the reactor and are considered the fresh feed to the system. The net product slate is divided by only the coal stream to determine W\% of feed coal. None of the other 5 fresh feed streams were used for this nn. The 10 product/recycle streams (VSOH, PFL, ASOH, VSB, PFC, etc...) are entered both as feed streams and as product streams. The met for each strean is calculated and used to determine the yields. The 5 non-fresh feed streams (makeup oil, dispersed catalyst, agglomerating oil) are considered as neither product/recycle nor fresh feed streans. They are considered as inert and simply pass through the system unchanged. The analysis for these streams is subtracted from the product slate as if they did not exist. If these streams are changed in the reaction then the analysis that would need to be entered for them would be the analysis of the products that they form. For this rum the only fresh feed stream that is used is the coal. All oil streams are handled as productirecycle streans or as non-fresh feed streams.

\section{Gus Analysis}

Two gas streams are provided in the program. These gas streams handle nitrogen and oxygen content differently due to the different strearns from the unit. The vent stream should contain no nitrogen or oxygen, just hytrogen and hydrocarbon gases. All nitrogen and oxygen in these streams is considered as a contaminari from air and eliminated from the analysis and the analysis of the gas fractions is renormalized to $100 \%$ and then applied to the entered gas flow. The bottoms gas strearns should contain nitrogen (from purges) but no oxygen. The oxygen is eliminated from the analysis along with a proportional amount of $N(79 / 21)$ as if the contaminant was air and then the analysis of the gas fractions is re-nomalized to $100 \%$ and applied to the entered gas flow.

\section{Normalization Factor}

The normalization factor was changed from one based upon total material recovery to one based upon carbon balance. The carbon content of all feed streams and product streams is calculated to equal $100 \%$ carbon balance. The nommalizalion factor is applied to alb gross (not net) product streams in order to achieve this. The normalized gross products are then used to calculate the net products and then the product fraction yieids.

The addition of TNPS to the feed affect the nomalized yield. According to a microautoclave test under coal liquefaction conditions, TNPS was decomposed to release $\mathrm{H}_{2} \mathrm{~S}$ and light hydrocarton gases. It was found that enty $12 \mathrm{~W} \%$ of hydrocarbon portion of TNPS was decomposed to forth gaseous products (majority is $C_{2}-C_{2}$ ) and the remaining 88 W\% was essentiafly light tiquid with a boiling range of IBP-343 ${ }^{\circ} \mathrm{C}$. As a result, in the nomalized yield calculation, the hydrocarbon portion of TNPS was backed out from corresponding gas and liguid products. 


\section{Sulfur and Nitrogen Bulance}

The sulfur and nitrogen balance are calculated and the difference is assumed to be the $\mathrm{H}_{2} \mathrm{~S}$ and $\mathrm{NH}_{3}$ product. This calculation forces these elements to balance. The stifur present in the feed $\mathrm{H}_{2} \mathrm{~S}$ and the TNPS is not included in these calculations, so the results will only reflect the $\mathrm{H}_{2} \mathrm{~S}$ and $\mathrm{NH}_{3}$ produced from coat.

\section{Desulfurization and Deaitrogenation}

The quantity of sulfur/nitrogen fed is defined as the sulfurinitrogen from the coal (organictinorganic). The quantity of sulfur in the products is defined as the net (product out- recycle fed in) for each of the product/recycle streams, except for PFC. The PFC is not inchuded in the product sulfur/nitrogen calculations. The sulfir present in the $\mathrm{H}_{2} \mathrm{~S}$ and the TNPS is not included in these calculations so that the results will only reflect sulfit/nitrogen removal from the coal.

\section{Ash Balance}

The total ash in the fresh feed is calculated. The quantity of ash present in the PFC is also calculated based upon actual collected PFC and PFC analysis. The quantity of PFC collected is then adjusted to achieve a $100 \%$ ash balance. The opposite of the adjustment that was applied to the PFC is applied to the PFL and its products (VSOH, VSB etc...). For example, if the PFC was adjusted down by 250 gms, then the PFL wouk be adjusted upward by 250 gms (or possibly the total of the VSOH and VSB would be adjusted upward by $250 \mathrm{gms}$, proportional to how they were produced from the PFL). This maintains the same material recovery as well as balancing the total ash.

\section{PFC Oil Content}

The oil content of the PFC is assumed to have the same analysis as the oil in the PFL. However, for those periods where there is no PFL analysis, the TGA analysis of the PFC is used to calculate a $524^{\circ} \mathrm{C}$ and a $524^{\circ} \mathrm{C}+$ content.

\section{Coal Conversion}

Coal conversion is calculated on both a straight basis and on a $\mathrm{SO}_{3}$ free basis. The $\mathrm{SO}_{3}$ free basis is caiculated by assuming that the sulfur content of the ash is in the form of $\mathrm{SO}_{3}$ which is eliminated from the total ash content. This adjustment is made to both the feed ash and the product ash. The option is given of which method to use for purposes of calculating and reporting yields and conversion.

\section{Water Yields and Orygen Balance}

Oxygen balarce is calculated and the water yield is adjusted to achieve $100 \%$ oxygen balance. 


\section{First Stage Coal and Resid Conversion}

The first stage slunry sample was separated into PFL and PFC by pressure filtration. The $Q I$ and ash contents of PFC and resid content of PFL were analyzed. The total ash in the feed streams (coal, recycle streans and catalyst) is calculated and the quantity of PFC is adjusted to achieve $100 \%$ ash balance. The IOM in adjusted PFC represents unconverted coal IOM and the IOM "carried over" from recycle PFC. The IOM in recycle PFC is considered to renain unchanged through K-1. In general, the first stage cosl conversion is calculated on the basis of maf cosl only.

The resid conversion is defined as ((Resid In-Resid Out)/Resid In)"100. The "Resid In" is the total resid in the feed streams inchuding coal IOM and resid from recycle streams while "Resid Out" is the total resid in the first stage suurry calculated through ash balance. 


\section{RESULTS AND DISCUSSIONS}

\section{Overall Process Performance}

In view of the complexity of the unit operations, especially the liquid/solid separation system, the overall materiaj balance for each operating day was exceptionally good. As shown in Table 8, material balance of most periods was between $96-100 \%$, except that of Periods 4,14,18,20 and 21 . Among these periods, only Period 20 was the last day of a process condition. As a result, results from Period 20 should be viewed with caution.

In Condition 5 , the foreign DW-HT distillate was not completely replaced with process derived distillate even after five days into the condition. However, the forejgn DW-HT distillate was produced from the same coal and used an all dispersed catalyst system. The use of non-steady solvent quality should not have a significant impact on the outcome of the test conditions.

Detailed naterial balance data from the 25 day operation is presented in Appendix A to E. The total recycle and recycle solid to MF coal feed ratio was within \pm 0.1 and \pm 2.1 of the target values, respectively (Table 8).

\section{Two Stage Performance}

\section{Coal Conversion}

Coal conversions reported in Table 10 and Appendices $\mathrm{A}$ to $\mathrm{E}$ are on an $\mathrm{SO}_{3}$-free basis, which serves as a common basis for comparing the raw coal and the low ash (low calcium) oil-agglomerated coal. Using an all dispersed catalyst system, coal conversion for all conditions varied from 93.4 to 98.7 w\%.

During the oil agglomerated coal conditions (Conditions 2 to 4 ), coal conversion was consistently bigher ( $3 \mathrm{~W} \%$ higher than raw coal conditions), indicating that oil agglomeration improves coal conversion, presumably because of reduced arganic rejection. From Condition 2 to Condition 3 , the same space velocity of $561 \mathrm{~kg} / \mathrm{h} / \mathrm{m}^{3}$ was maintained while the catalyst concentration was reduced by $30 \mathrm{~W} \%$. The reduction in make-up catalyst concentration didr't affect coal conversion. It should be noted that from Condition 2 to Condition 3, the ratio of ash/MF coal in the recycle stream increased from $13.9 \mathrm{~W} \%$ to $14.7 \mathrm{~W} \%$, implying that slightly more spent catalyst was added to the recycle stream.

Coal conversion obtained from Condition 5 may be conpared with that from Condition 1, since raw coal was used in both conditions. Condition 5 was operated under lower space velocity $\left(176 \mathrm{~kg} / \mathrm{h} / \mathrm{m}^{3}\right.$ lower than in Condition 1) and lower fresh catalyst concentration ( $30 \mathrm{W \%}$ lower) but using dewaxed-hydrotreated VSOH as solvents. Coal corversion retumed to $94.7 \mathrm{~W} \%$ maf coal, the same as obtained in Condition 1. 
$524^{\circ} \mathrm{C}^{+}$Residumn Conversion

The $524^{\circ} \mathrm{C}+$ resid conversion represents the ability of the process to convert high boiling fractions contained in the feedstocks. The resid conversion is an important measure of the process performance or catalytic activity. For the purpose of calculation, all of the maf portion of the feed coal is considered as $524^{\circ} \mathrm{C}+$ resid.

As shown in Table 10, the resid conversion values varied between 82.3 and $92.9 \mathrm{~W} \%$. From Condition 2 (Period 12) to Condition 3 (Period 17), the resid conversion didn't drop, although makeup catalyst concentration was reduced by $30 \mathrm{~W} \%$.

Starting from Condition 4 , the space velocity was further reduced to $420 \mathrm{~kg} / \mathrm{h} / \mathrm{m}^{3}$, therefore extinction recycle of $413^{\circ} \mathrm{C}+$ VSB was almost achieved. The adjusting of space velocity caused the expected increase in resid conversion by $5.7 \mathrm{~W} \%$ from Condition 3 to Condition 4 .

Although raw coal was used in Conditions 1 and 5 , the comparison of $524^{\circ} \mathrm{C}+$ resid conversion between two conditions was very difficult, since changes in catalyst concentration, space velocity and soivent quality were made in condition 5 . The effect of solvent dewaxing and hydrotreating on resid conversion was not clear based on the data available.

\section{Distillate Yieid (C4-524 ${ }^{\circ} \mathrm{C}$ and $\mathrm{IBP}-34^{\circ} 3^{\circ}$ ) and $524^{\circ} \mathrm{C}^{\circ}$ Residunn Yield}

During Run ALC-1, $\mathrm{C}_{4}-524^{\circ} \mathrm{C}$ distillate yield varied between 60.2 and $69.0 \mathrm{~W} \%$ maf coal. As shown in Table 10 and Figure 11 , during oil-agglomerated coal feed conditions (Conditions 2 through 4 ), $\mathrm{C}_{4}-524^{\circ} \mathrm{C}$ distillate yield was increased from 60.2 to $66.1 \mathrm{~W} \%$ maf caal. The significant increase in distillate yield is believed to be due to the reduction of space velocity from 530 to $420 \mathrm{~kg} / \mathrm{h} / \mathrm{m}^{3}$, causing success in extinction recycle of heavy boiling VSB. The highest $524^{\circ} \mathrm{C}+$ resid yitld was obtained in Condition 2. The inefficiency of the vacuum still may be responsible for high resid yield.

One of the objectives of Run ALC-1 was to maximize the yield of IBP-343 $33^{\circ} \mathrm{C}$ distillate yield through different means, including coal deashing, solvent dewaxing and hydrotreating and extinction recycle of VSB. As indicated in Table 10, the yield of IBP-3430 C light distillate obtained from Condition 4 was higher than from Conditions 1 through 3 , because of the reduction in space velocity and the near extinction recycle of $524^{\circ} \mathrm{C}+$ resid. It is interesting to note that the highest yield of $\mathrm{BBP} \cdot 343^{\circ} \mathrm{C}$ light distillate was obtained in Condition 5, possibly demonstrating the benefit of solvent dewaxing and hydrotreating.

\section{Distillare Yield and Selectivity}

The naphtha yield is defined as the $\mathrm{C}_{4}-177^{\circ} \mathrm{C}$ product fraction and is shown in Figure 12 and Table 10. The naphtha yield increases, in comparing Conditions 1 and 4 , from 18.6 to $23.0 \mathrm{~W} \%$ maf coal together with increases in heavy gas yield. The highest naphtha yield obtained in Condition 4 may be due to the significant reduction in space velocity (to $420 \mathrm{~kg} / \mathrm{h}^{\prime} \mathrm{m}^{3}$ ). 
The middle distillate yield is defined as the $177-343^{\circ} \mathrm{C}$ product fraction and is shown in Table 10 and Figure 12. In comparing the oil-aggtomerated coal Conditions 2 and 4, a trend of increase in middle distillate yield was observed. All these results have indicated that the modifications that were made during Conditions 2 through 4 had a positive impact on the process performance.

The heony distrillate yield is defined as the $343-524^{\circ} \mathrm{C}$ product fraction and is shown in Table 10 and Figure 12. The highest heavy distillate yield was obtained from Condition 2.

Selectivity of distiflate yields are shown in Table 10 and Figure 13.

Hydrogen Consumption and Lijght $\mathrm{C}_{1}-\mathrm{C}_{3}$ Gas Yield

The hydrogen consumption for the Run ALC-1 is presented in Figure 14 and Table 10. The hydrogen consumption was $7.5 \mathrm{~W} \%$ maf coal in Condition 1 . Hydrogen consumption was reduced by about $1.0 \mathrm{~W} \%$ on switching to oil-agslomerated coll from the raw col condition. During oil-agglomerated coal conditions, the slightly higher hydroget consumption in Condition $\mathbf{4}$ was due to the decrease in space velocity.

The $C_{1}-C_{3}$ gas yield varied from $9.4 \mathrm{~W} \%$ to $12.4 \mathrm{~W} \%$ maf coal. The highest yield of $\mathbf{C}-C_{\text {gas }}$ obtained in Condition 4 was due to the reduction in space velocity, causing extensive cracking.

\section{Performance of Dewaxer and Hvdrotreater}

Prior to the Run ALC-1, HTt prepared about $213 \mathrm{~kg}$ DW-HT VSOH. The ASTM D1160 analysis on these dewaxed VSOH and DW-HT VSOH is shown in Table 6 . After hydrotreating, the IBP$343^{\circ} \mathrm{C}$ traction increased from $22.0 \mathrm{~W} \%$ to $44.5 \mathrm{~W} \%$, implying that significant hydrocracking of dewaxed VSOH occurred during hydrokreating. It seemed that hydrotreating temperature of $371^{\circ} \mathrm{C}$ was too high.

As a result, in Condition S, the off-line fyydrotreater temperature was reduced to $360^{\circ} \mathrm{C}$ and dewaxed VSOH flow rate was increased from 500 to $650 \mathrm{~g} / \mathrm{h}$. This adjustments appeared to be effective. As shown in Table 21, the hydrogen content in DW-HT VSOH increased from $8.68 \mathrm{~W} \%$ to $9.74 \mathrm{~W} \%$ while the IBP-343 ${ }^{\circ} \mathrm{C}$ fraction dida't seem to increase significantly. This suggests that the hydrocracking reaction can be suppressed at relatively lower temperature and higher throughput.

\section{First Stage Performance}

\section{Coal and $524^{\circ} \mathrm{C}^{*}$ Residuum Conversion}

As shown in Table 11, coal conversion obtained from first stage reactor (K-1) varied from 94,2-96.9 W\%. The highest coal conversion was obtained in Condition 4 due to decrease in space velocity. On an average, first stage coal conversion was $0.5-1.0 \mathrm{~W} \%$ less than overalt coal conversion. 
$524^{\circ} \mathrm{C}+$ resid conversion from the first stage varied from 46.2 to $66.9 \mathrm{~W} \%$, about $30 \mathrm{W \%}$ lower than total resid conversion. It seems that resid conversion depends more on residence time than coal conversion does.

\section{Gas Yield}

As shown in Appendix A-E, the yield of $\mathrm{C}_{1}-\mathrm{C}_{3}$ gases obtained from first stage varied between 4.0 and $7.2 \mathrm{~W} \%$ of maf coal, about $50 \%$ of the total $C_{1}-C_{3}$ gas yield (both stages). On an average, the yieid of first stage $C_{4}-C_{7}$ gases was about $42-45$ W\% of total $C_{4}-C_{7}$ gas yield.

The yield of $\mathrm{COx}$ from the firs stage was above $90 \mathrm{~W} \%$ of total $\mathrm{COx}$ production from both stages.

\section{Analyses of Interstage Samples (SOH, PFL and PFC)}

The interstage SOH oil contained lower hydrogen but higher sulfur and nitrogen contents than second stage SOH oit (hydrotreated). As shown in Tables 12 \& 18 , in most conditions, about 50 $\%$ of sulfur removal from first stage $\mathrm{SOH}$ oil was achieved and nitrogen removal was $75 \mathrm{~W} \%$ in the on-line hydrotreater. According to the results from previous bench runs performed in HTI, $99 \%$ of heteroaton removal could be achieved if the hydrotreaters were operated efficiently. Compared with second stage SOH oil, the IBP- $177^{\circ} \mathrm{C}$ and $343^{\circ} \mathrm{C}$ - fractions of the first stage oil were lower, especially for those obtained fiom ol-agglomerated coal conditions. In addition, an increase in SOH H/C ratio was observed through the second stage.

The interstage PFL, was obtained from the laboralory pressure filtration of slumy samples for samplehanding convenience. As shown in Tables 19, the API gravity, IBP, and even elemental analysis for interstage PFL are quite similar as compared to second stage PFL(Table 13, Period 6). However, interstage PFL contains about $10 \mathrm{~W} \%$ more $524^{\circ} \mathrm{C}+$ resid than second stage PFL, which is consistent with lower resid comversion obtained from interstage. In addition, the cyclohexane and toluene insolubles are higher than second stage PFL.

No significant difference was observed between the properties of interslage PFC and second stage PFC. 


\section{PRODUCT QUALITY}

Detailed aralyses were carried oux on liquid products including $\mathrm{SOH}$ oil (first stage and 2nd stage), VSOH, VSB, PFL, and PFC produced from work-up Periods. D1 160 distillation was performed on daily basis to belp fine tune the unit. In addition, for each Period, ash content and quinoline insolubles in PFC were analyzed to control the solid concentration in the recycle stream.

\section{2nd Stage Separator Overhead Product}

The SOH oil stream represents the net light distillate (IBP-343 ${ }^{\circ} \mathrm{C}$ ) from Run ALC-1. While the hydrotreater unit was on-line during the run, a major distillate stream out of the unit was the SOH stream, as the 0.1 hot separator overheads, interstage separator overtieads, and unit knockouts were being fed directly to the bydrotreater. The properties of SOH oil for the work-up periods are shown in Table 12 . The $\mathrm{SOH}$ oils had a typical boiling range of $43-40 \mathrm{I}^{\circ} \mathrm{C}$. The API gravities were high

$(>33.9)$, and $\mathrm{H} / \mathrm{C}$ atomic ratios were also high ( $>1.67$ ), especialty during oil agglomerated caal conditions. IBP-177C, the lightest fraction of the SOH-oil, was also higher during oil agglomerated coal conditions than during coal-only conditions. It is observed from the beginning of Run ALC-1 that the hydrotreater was not performing effectively. According to the results from previous nuns, sulfur levels below $75 \mathrm{ppm}$ and nitrogen levels below $50 \mathrm{ppm}$ should be obtained after in-line hydrotreating. Starting from Period 3, the sulfur content in second stage was around 1100 pprn as compared to $3000 \mathrm{ppm}$ of first stage $\mathrm{SOH}$ oil. This implies that the hydrotreater was not perfoming efficiently. Unfortunately, $a$ change out of the hydrotreater catalyst during the nun was impossible.

\section{Pressure Filter Liquid (PFL) and Pressure Filter Cake (PFC)}

From Period 5 of Run ALC-1, the continuous atmospheric still was taker off-line. As a result, the CAS was bypassed and the separator bottons were collected through a low pressure flash vessel (V-100). The siury from V-100 was charged to the pressure filter for separation of solids from the heavy liquid product and recycle oil. The liquid oil (PFL) uscally contains more than $80 \mathrm{~W} \%$ $343^{\circ} \mathrm{C}+$ including unreacted heavy residuum material. The solids from pressure filtration, PFC, are oit-containing solids, normally extracted with toluene for oil recovery. The oil-firee solids were then used for determining the extent of coal conversion based on the solubility of the PFC material in quinoline.

During Run ALC-1, PFL was used as recycle solvent only in Condition 1. Starting from Condition 2 , the entire PFL was fractionated into VSOH and VSB. VSOH was partially recycled and extinction recycle of VSB was attempted. As shown in Table 13, The ASTM D1160 distillation indicated that the PFL contained $17 \mathrm{~W} \% \mathbb{I B P}-343^{\circ} \mathrm{C}$ whereas the $524{ }^{\circ} \mathrm{C}+$ resid content was about $29 \mathrm{~W} \%$. Elemental analysis showed that the bydroges comtent was about $7.6 \mathrm{~W} \%$ and sulfur content was around $1.03 \mathrm{~W} \%$. The amounts of preasphaltenes and asphaltenes in PFL, characterized by solubilities in toluene and cyclohexane respectively, are also shown in Table 13.

Pressure filter cake was analyzed on a daily basis to control the solid concentration. In Condition 1, 
the PFC was extracted with tojuene prior to recycle which is shown in Table $\$ 6$. This caused the solid content of toluene-extracted PFC to be high (80-86\%). Starting from Condition 2, the PFC was recycled without toluene wash, which caused a decrease in solid content ( fluctuated around 60\%). The variation of elemental content $(C, H, S, N)$ of $\mathrm{PFC}$ was not stignificant.

\section{Qaality of VSOH (Condition 2-5)}

From Condition 3 to Condition 5 , VSOH was fractionated into $\mathrm{VSOH}_{1}$ and $\mathrm{VSOH}_{2}$ by vacuum distillation. The cut point was set at $343^{\circ} \mathrm{C}$. The $\mathrm{VSOH}_{1}$ represents the $343^{\circ} \mathrm{C}$ - fraction while $\mathrm{VSOH}_{2}$ consists of $343^{\circ} \mathrm{C}+$ fraction which was being recycled. As shown in Table 13, the AP] of VSOH, varied from 10.2 to 16.2 , bul the $\mathrm{API}$ of $\mathrm{VSOH}_{2}$ did not change very much.

The hydroger pontents of $\mathrm{VSOH}_{1}$ and $\mathrm{VSOH}_{2}$ obtained from Condition 5 were higher than those from Conditions 3 and 4 , due to the bydrotreating. It is expected that the donatable hydrogen content was enhanced after dewaxing and hydrotrotreating. It is interesting to note that the $\mathrm{H} / \mathrm{C}$ ratio for VSOH, obtained during Condition 5 was the highest (1.45) whereas $S$ and $N$ contents were the lowest, indicating that, to a certain extent, dewaxing and hydrotreating had improved the quality of the solvents.

\section{Quality of VSB (Condition 1-5)}

The cut-points of the VSB used in each condition were different. The VSB used in recycle stream of Condition I was obtained from toluene-extracted oil fractionated at cut point of $390^{\circ} \mathrm{C}$. The VSB used in Conditions 2, 3 and 4 was derived from PFL fractioned at cut point of $413^{\circ} \mathrm{C}$ whereas VSB generated in Condition 5 was essentially $524^{\circ} \mathrm{C}+$.

As shown in Table 14, the analyses of the VSB for Conditions 1 through 4 indicates that API, elemental composition and ASTM D-1160 for all VSB are quite similar, except that higher hydrogen content VSB were produced during oil agglomerated-coal conditions.

\section{Qrality of Unrefined Wax (Condition 5)}

Dewaxing and hydrotreating of $\mathrm{VSOH}$ was performed in Condition 5 . The wax sample received from the dewaxing unit contained oil and acetone. After removal of contaminates by chilling in acetone, the unrefined wax yield for each period was measured and appeared to be about $5 \mathrm{~W} \% \mathrm{mf}$ coal. The waxes obtained from Perjods 22-25 were characterized by elemental analysis, TGA and GC-MS. As stown in Table 15, the wax produced in Work-up Period 25 contains $13.22 \%$ hydrogea and high $\mathrm{H} / \mathrm{C}$ ratio. $524^{\circ} \mathrm{C}+$ resid content, as characterized by TGA, varied from 0.28 to $4.39 \mathrm{~W} \%$. For paraffinic compounds, $524^{\circ} \mathrm{C}$ is about the boiling point of $n-C_{3 s}$, suggesting that the waxes generated from coal liguefaction are light waxes with carbon number lower than $C_{40}$.

This has been confinmed by GC and GC-MS anafysis. As shown in Table 15, the carbon number distribution is mainly in the range of $\mathrm{C}_{18} \cdot \mathrm{C}_{96^{*}}$. These waxes are mixtures of straight chain and 
multibranched paraffins according to GC-MS analysis.

Amalysis of True Boiling Point (TBP) Fractions (ASTM 2892, modified by HTT)

The SOH and VSOH were fractioned into four true boiling point (TBP) fractions and the individual boiling fractions were combined according to their production rate to produce a single product for each fraction of interest. These fractions were then analyzed for the chemical and physical properties. The TBP fractions were analyzed for each operating conditions. Results are summarized and shown in Tables 22 throught 28.

The IBP- $177^{\circ} \mathrm{C}$ fraction of each condition contained about $50 \mathrm{~W} \%$ paraffins and $40 \mathrm{~W} \%$ naphthenes; the aromatic and olefinic contents were low. The aromatic content increased with the increase in boiling point.

\section{Pheaolic Content and Simnlated Distilation of Separator Overhead}

Phenolic contents of first stage and second stage $\mathrm{SOH}$ were analyzed and the results are presented in Table 29. The water fraction of first stage SOH contained 6.7 times more phenolics than the second stage SOH water. The hydrotreated SOH oil (second stage) contained significant lower phenolics than the first stage, indicating that the use of in-line hydrotreater tends to convert phenolic compounds. If phenolic compounds are considered as valuable products, it may be necessary to separate phenolic compounds from the first stage $\mathrm{SOH}$ before hydrotreating.

Simulajed distillation of $\mathrm{SOH}$ oil fractions was carjed out and the results are summarized in Appendix G.

The loss of phenolics and other organics in the $\$ O H$ water was considered in the calculation of normalized yield. The carbon content of SOH water was analyzed by CONSOL (Appendix $\mathrm{H}$ ). The results indicated that the carbon loss in SOH water fraction only had a minor influence on the distillate yield (Appendix I).

\section{Characterization of On-Line FTU Catalyst and Solvent Fydrotreating Catalyst}

Previous bench run results indicated that $>99 \%$ heteroatom removal can be achieved. However, it was observed from Period 3 of Run ALC-1 that the sulfur and nitrogen removal from the SOH oil was only $75 \mathrm{~W} \%$. The in-line HTU catalyst was characterized after the run and the results are shown in Table 26. A significant reduction in surface area and pore volume was observed, indicating deactivation of the catalyst. It might be possible that during the early part of Condition 1 , heavy materials from CAS overbead was fed to HTU causing coking (carbon deposit) of the hydrotreating catalyst.

The surface ares and pore volume of solvent hydrotreating catalyst did not change significantly as compared to fresh catalyst. 


\section{CONCLUSIONS}

From this 25 day, all slurry catalyst bench scale operation, the following major conclusions may be drawn:

1. Using iron (1 w\%) and molybdenum (100 ppm) based dispersed catalysts, two-stage liquefaction of Black Thunder coal is a sustainable operation resulting coal conversion of over $95 \%$ and $\mathrm{C}_{4}-524^{\circ} \mathrm{C}$ liquid yield of $69 \mathrm{~W} \%$ maf coal.

2. The oil agglomeration deashing procedure selectively reduced the calcjum content of Black Thunder coal. The ash content of raw coal was reduced by $40 \%$ from 5.5 to $3.3 \%$ (mf. SO free basis). The oil agglomerated coal was more active. Coal conversion was 3 w\% higher than the raw Black Thunder coal. However, due to the use of foreign agglomerating oil and recycling of low boiling materials(inefficiency of the vacuum still), this potential improvement was not observed in the distillation yield.

3. The oil agglomerates were easily re-dispersed in the recycle solvent.

4. Fresh catsiyst make-up rate was reduced by $30 \%$, with no apparent detrimental effect in process performance with either raw coal or oil agglometated coal.

5. Extinction of $343^{\circ} \mathrm{C}$ material was not achieved. However, as the space velocity was reduced

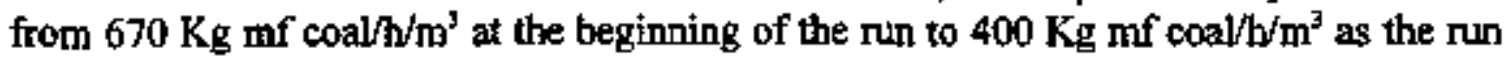
progressed, the operation was approaching near extinction of the $413^{\circ} \mathrm{C}$ matertials $(0.81$ W\%).

6. Treatment of recycle solvent was successfully demonstrated, however, steady state operation was not achieved. 


\section{RECOMMENDATION FOR FUTURE WORK}

Atthough ALC-01 detnonstrated the viability of all slury catalyst operation, it also identified several areas for potential improvements:

1. Make-up catalyst rate of $7000 \mathrm{ppm}$ of Fe and $70 \mathrm{ppm}$ Mo was demonstrated suxcessfilly. However, in onder to further redice catalyst cost, Jower catalyst concentrations should be explored.

2. The goal of extincting $343^{\circ} \mathrm{C}+$ material was far from being achieved even after significant reduction in feodstock space velocity. This criterion may not be practical for an all slury catalyst system. Extinction of the $413^{\circ} \mathrm{C}+$ was almost accomplished in Condition 4 .

3. Feed blending on a 1 to 2 hours besis provided accurate control of the solvent to coal and recycle solid to feed coal ratios. However, in order to maintain a more consistent recycle solvent quality, it is tecommended to increase the feed blending time to 4 to 6 hours.

4. Since the beginning of the jun, heteroatoms contemt of distillate products were significantly bigher than anticipated, suggesting that the catalyst in the direct-coupled hydrotreater was poisoned. The excessive catalyst deactivation was due to the flooding of the Atmospheric Still with beavy resjdues and solids. As a result, atmospheric still overheads fed to the direct-coupiei hydrotreater contained bigh boiling materials. For Run ALC-02, a continuous flow single-stage vacturn flash followed by a redaced pressure packed bed still is recommended to provide a sharper cut point for the hydrotreater feed.

5. The generation of recycle solvent for Run ALC-01 was rather complex consisting of hot separator slumy bottorn, toluene extracted oil from the filter cake, and two cuts of vacuum still overheads ( $\mathrm{VSOH}_{1}$ and $\left.\mathrm{VSOH}_{2}\right)$. The complexity as well as the time required for each of the recovery operation had slowed down the approach to steady state. The following improvements at the solvent recovery section are recommended.

- filtration cycle time: a large plate filter, continue with the addition of light distillate to reduce viscosity.

- vacuum still: a continuous flow vaculum still with inclined half-plate to increase contacting surface.

- reduced pressure still: a packed column still for providing better separation and shaper cut point of distillates ( $f^{\text {t }}$ stage overheads and second state distillates) to the hydrotreater.

6. The use of sulfidation agent to activate the catalyst precursors was arbitrarily chosen as 3 W\% of mf coal for each stage. This amount has to be further optimized from the cost point of view. Also, the question of whether addition of sulfidation agent is needed for the second stage should be addresseo. 


\section{Table 1. Analysis of Feed Black Thunder Mine Coal}

FTI Designation

Molsture Content, W\%

Proximate Anglysis, W\% Dry

Volatile Matter

Fixed Carbon

Mineral Matter

Ultimate Analysis, W\% Dry

Carbon

Hydrogen

Nitrogen

Sulfur

Ash

Oxygen (Diff.)

H/C Atomic Ratio
HTI 6213

10.01

43.48

50.52

6.00

70.12

5.11

0.99

0.35

6.19

1724

0.88

Moisture Content of Oil-Agglomerated Coal (Analyzed by HTI)

\begin{tabular}{|l|c|c|c|c|c|c|c|c|c|c|}
\hline $\begin{array}{l}\text { OA Coal } \\
\text { Bagf }\end{array}$ & C1 & C2 & C3 & C4 & C5 & C6 & C7 & C8 & C9 & C10 \\
\hline Moisture & 5.59 & 5.90 & 7.50 & 5.99 & 7.49 & 7.59 & 7.20 & 7.89 & 7.89 & 9.01 \\
\hline
\end{tabular}




\section{Table 2. Analysis of Agglomerating Oil}

HII Designation

API Gravity, *

Elemental Analysis, W\%

Carbon

Hydrogen

Sulfur

Nitrogen
HTI 6460

3.6

89.45

9.16

0.025

0.103

\section{ASTM D-1160 Distillation, ${ }^{\circ} \mathrm{C}$}

IBP

$5 \mathrm{~V} \%$

$10 \mathrm{~V} \%$

$20 \mathrm{~V} \%$

$30 \mathrm{~V} \%$

$40 \mathrm{~V} \%$

$50 \mathrm{~V} \%$

$60 \mathrm{~V} \%$

$70 \mathrm{~V} \%$

$80 \mathrm{~V} \%$

$90 \mathrm{~V} \%$

$95 \mathrm{~V} \%$

$98 \mathrm{~V} \%$
392

402

406

413

420

427

434

442

454

460

481

494

524

66.67

29.23

3.72

0.38 


\section{Table 3. Composition of Agglomerate Products From Runs C1-C10 (RUN ALC-1 Feedstocks)}

\begin{tabular}{|c|c|c|c|c|c|c|c|c|c|c|c|c|}
\hline & \multicolumn{12}{|c|}{ Bag No. } \\
\hline & $\mathrm{C2}$ & c3 & C4 & c5 & Co & c7 & $\mathrm{Cg}$ & $\cos$ & $\mathrm{C} 6+\mathrm{C} 7$ & c1 & Cto & $\begin{array}{l}\text { C2-C9 Avg. } \\
\text { tStd Dov. }\end{array}$ \\
\hline \multicolumn{13}{|c|}{ Composition, wh $\%$ of Whole Semple } \\
\hline Moistere & 5.77 & 8,10 & 6.65 & 7.90 & 7.64 & 7.79 & 6.12 & 8.67 & 7.48 & $5,4 B$ & 9.32 & $7.58 \pm 0.93$ \\
\hline Agglom. Oil & 24.06 & 23,40 & 23.62 & 23.36 & 23.46 & 23.43 & 23.41 & 23.34 & 23.49 & 23.28 & 22.95 & $23.51 \pm 0.24$ \\
\hline Ash, $\mathrm{SO}_{\text {, line }}$ & 2.37 & 2.34 & 2.47 & 2.37 & 2.27 & 2.33 & 2.29 & 2.26 & 2.35 & 2.68 & 2.28 & $2.34 \pm 0.07$ \\
\hline MAF Coaf & 67.81 & 66.15 & 67.25 & 66.37 & 66.63 & 66.44 & $66.1 \mathrm{~d}$ & 6573 & 66.68 & 68.55 & 65.45 & $66.57 \pm 0.66$ \\
\hline $\begin{array}{l}\text { Mif Coal (MaF } \\
\mathrm{Coal}+\mathrm{ASh})\end{array}$ & 70.17 & 68.50 & 69.73 & 68.74 & 68.90 & 68.78 & 68.47 & 67.99 & 69.03 & 71.24 & 67.73 & $68.91 \pm 0.71$ \\
\hline \multicolumn{13}{|c|}{ Addlional Anabzes, wt \% of Whole Sample, As-Delermined } \\
\hline Carbon & 71.61 & 70.14 & 71.11 & 69.88 & 69.92 & 70.12 & 69.76 & 60.90 & 69.97 & 71.57 & 69.17 & $70.18 \pm 0.84$ \\
\hline Hydrogen" & 6.31 & 6.61 & B. 49 & 6.64 & 6.58 & 0.40 & 6.69 & 6,48 & 6.42 & 6.44 & 6.55 & $6.52 \pm 0.13$ \\
\hline Närogen & 0.82 & 0.79 & 0.81 & 0.60 & 0.80 & 0.60 & 0.81 & 0.79 & 0.80 & 0.82 & 0.77 & $0.80 \pm 0.01$ \\
\hline Sullur & 0.71 & 0.69 & 0.72 & 0.67 & 0.70 & 0.67 & 0.69 & 0.67 & 0.68 & 0.63 & 0.64 & $0.69 \pm 0.02$ \\
\hline $\begin{array}{l}\text { Heating Value, } \\
\text { Btulf }\end{array}$ & 12812 & 12570 & 12896 & 12592 & 12647 & 12624 & 12553 & 12435 & 12578 & $\begin{array}{r}1201 \\
9\end{array}$ & 12216 & $12640 \pm 145$ \\
\hline \multicolumn{13}{|c|}{ Elemental Compostion, wt \% of MF Coga Poution of Agglomerates (Cakculaled on Oit-Free, Moisture-Free, Ash-SO,-Free Basis) } \\
\hline Asth $\mathrm{SO}_{3}-\mathrm{Fr} \theta 0$ & 3.27 & 3.28 & 3.46 & 3.37 & 3.23 & 3,27 & 3.25 & 3.02 & 3.37 & 3.56 & 3.28 & $3.27 \pm 0.13$ \\
\hline Carbon & 71.36 & 71.84 & 71.64 & 71.22 & 70.98 & 71.46 & 71.26 & 70.74 & 70.84 & 71,29 & 70.29 & $71,31 \pm 0,35$ \\
\hline Hydrogen"* & 5.05 & 5.31 & 526 & 5.37 & 5,30 & 5.04 & 5.43 & 5.09 & 5.09 & 5.31 & 5.15 & $523 \pm 0.15$ \\
\hline Natrogen & 0.96 & 0.95 & 0.96 & 0.96 & 0.98 & 0.96 & 0.98 & 0.96 & 0.96 & 0.96 & 0.94 & $0.96 \pm 0.01$ \\
\hline Sulfur & 1.01 & 0.99 & 1,03 & 0.97 & 1.00 & 0.96 & 0.09 & 0.97 & 0.97 & 0.88 & 0.94 & $0.99 \pm 0.02$ \\
\hline onrgen by Diff. & 18.36 & 17.62 & 17.66 & 18.12 & 18.53 & 18.34 & 18.09 & 19.21 & 18.77 & 18.00 & 19.41 & $18.24 \neq 0.51$ \\
\hline
\end{tabular}

Includes hydrogen frem moisture (as-determined basis).

Corrected to exclude hydrogen from moisture. 
Table 4. Major Elemental Analysis of Ash in Oil-Agglomerated Coal*

Raw Coal Oil-Aggl.Coal Baw/Oil-Agol.

$\begin{array}{lrrr}\mathrm{Na}_{2} \mathrm{O} & 1.75 & 0.41 & 4.27 \\ \mathrm{~K}_{2} \mathrm{O} & 0.51 & 0.53 & 0.96 \\ \mathrm{CaO} & 25.78 & 8.99 & 2.87 \\ \mathrm{MgO} & 5.40 & 1.45 & 3.72 \\ \mathrm{Fe}_{2} \mathrm{O}_{3} & 6.66 & 8.87 & 0.75 \\ \mathrm{TiO}_{2} & 1.45 & 2.51 & 0.58 \\ \mathrm{P}_{2} \mathrm{O}_{5} & 1.36 & 2.13 & 0.64 \\ \mathrm{SiO}_{2} & 37.34 & 47.84 & 0.78 \\ \mathrm{Al}_{2} \mathrm{O}_{3} & 19.14 & 26.93 & 0.71 \\ \text { Total } & 99.40 & 99.65 & \end{array}$

* Analysis Performed by CONSOL inc. 
Table 5. Analysis of Start-up/Make-up Oil

HII Designation

API Gravity, *

ASTM D-1160 Disttllation, ${ }^{\circ} \mathrm{C}$

IBP

$5 \mathrm{~V} \%$

$10 \mathrm{~V} \%$

$20 \mathrm{~V} \%$

$30 \mathrm{~V} \%$

$40 \mathrm{~V} \%$

$50 \mathrm{~V} \%$

$60 \mathrm{~V} \%$

$70 \mathrm{~V} \%$

$80 \mathrm{~V} \%$

$84 \mathrm{~V} \%$

Weight Percents

IBP- $343^{\circ} \mathrm{C}$

$343-454^{\circ} \mathrm{C}$

$454-524^{\circ} \mathrm{C}$

$524^{\circ} \mathrm{C}^{\circ}$

Elemental Analysis, W\%

Carbon

Hydrogen

Sulfur

Nitrogen

\section{NMR Data}

W\% Aromatic Carbon

W\% Cyclic Hydrogen
88.03

Filtered L-814

0.40

309

351

374

394

409

426

437

449

467

507

524

5.47

53.99

22.18

18.36

88.96

8.25

2.22

0.19

44.36 


\section{Table 6. Properties of Pre-Prepared DW-HT VSOH}

Stream

API Gravity

IBP, ${ }^{\circ} \mathrm{C}$

Elemental Analysis

Carbon

DW-VSOH

DW-HT VSOH

14.6

60
DW-HT VSOH

(3.43\% + , mogded)

7.8

324

Hydrogen

88.10

Sulfur

8.47

0.76

Nitrogen

0.65

$\mathrm{H} / \mathrm{C}$

ASTM D-1160 Distillation, Composition, $W \%$

$\begin{array}{lrrr}\text { [BP-343. } \mathrm{C} & 22.00 & 44.53 & 4.06 \\ 343-454^{\circ} \mathrm{C} & 59.62 & 52.16 & 87.40 \\ 454-524^{\circ} \mathrm{C} & 14.57 & 2.27 & 5.19 \\ 524^{\circ} \mathrm{C} t & 2.86 & 0.00 & 2.76 \\ \text { LOSS } & 0.95 & 1.04 & 0.59\end{array}$

Note: $\mathrm{VSOH}=524^{\circ} \mathrm{C}$ - fraction of PFL; DW-VSOH= dewaxed VSOH

DW-HT VSOH=dewaxed-hydrotreated VSOH 


\section{Table 7. ALC-1 Bench Run (227-94) Detailed Plan}

Conditions

Periods

Temperature, ${ }^{\circ} \mathrm{C}$

Pretreater

$\mathrm{K}-1$

$\mathrm{K}-2$

In-line Hydrotreater

Still Cut Point, ${ }^{\circ} \mathrm{C}$

V-100 Flasher

Vacuum Still

Back Pressure, MPa

$\mathbf{H}_{2}$ Flow Rate, Std Liter/h

K1 Main

K1 Ebb Line

K2 Ebb Lire

Separators

$\begin{array}{lllll}1 & 2 & 3 & 4 & 5 \\ 1-6 & 7-13 & 14-17 & 18-20 & 21-25\end{array}$

$300 \quad 300$

300

440

450

379

300

440

450

379

300

440

450

379

329

524

$\begin{array}{lllll}329 & 329 & 329 & 329 & 329 \\ \text { N/A } & 412 & 412 & 412 & 524\end{array}$

Space Velocity

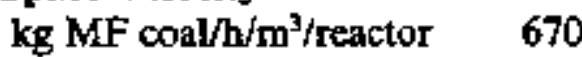

560

560

400

480

Coal Flow Rate, g/h

Raw Coal @ 10\% Moisture 1488

OA Coal $Q 8 \%$ Moisture and --

$23.4 \% \mathrm{OH}$

$\begin{array}{llll}-3 & -1068 & 1068\end{array}$

Recycle Stream Flow Rate, g/h

Buffer Oils(K1 +K2) 107

PFL

1678

PFC

357

VSB

-- 941

90

90

64

77

VSOH(DW-HT 650F+)

$+$

Total Recycie/mf Coal

1. 60

1.60

$-$

380

$-$

$-$

380

271

320

$941 \quad 672$

457

Total Solid/mf Coal

0.20

0.20

1.60

-

665

Catalyst Addition Rate, g/h

$\mathrm{Fe}$ Catalyst $(10 \mathrm{w} \% \mathrm{Fe})$

Molyvan-A(29w\% Mo)

134

0.46

111

79

56

67

TNPS (37 W\% S) to K-1

0.38

0.27

1.60

1.52

0.20

0.20

0.20

$\mathrm{H}_{2} \mathrm{~S}$ to $\mathrm{K}-2, \mathrm{~g} / \mathrm{h}$

0.19

0.23

64

78

40

40

40 
Table 8. Daily Material Balance and Recycle Concentration

\begin{tabular}{ccccccccc} 
& \multicolumn{8}{c}{ Total Material Balance } \\
Conditions & 1 & 2 & 3 & 4 & 5 & 6 & 7 & Average \\
& & & & & & & & \\
1 & 99.8 & 96.3 & 96.1 & 94.2 & 96.9 & 97.0 & & $96.7++\cdot 1.8$ \\
2 & 100.2 & 99.2 & 99.2 & 96.1 & 100.3 & 96.4 & 97.9 & $96.5+r-1.7$ \\
3 & 91.9 & 96.3 & 96.1 & 95.5 & & & & $95.0+1-2.1$ \\
4 & 94.7 & 96.6 & 92.0 & & & & & $94.4+j-2.3$ \\
5 & 94.5 & 95.9 & 98.1 & 97.1 & 96.1 & & & $96.3+J-1.3$
\end{tabular}

Total Rocyclo/mf Coal Ratio

$\begin{array}{ccccccccc}\text { Conditions } & 1 & 2 & 3 & 4 & 5 & 6 & 7 & \text { Average } \\ 1 & 2.3 & 1.6 & 1.6 & 1.6 & 1.6 & 1.6 & & 1.7+1-0.29 \\ 2 & 1.6 & 1.6 & 1.6 & 1.6 & 1.9 & 1.7 & 1.6 & 1.7+1-0.13 \\ 3 & 1.7 & 1.6 & 1.6 & 1.6 & & & & 1.6+1-0.03 \\ 4 & 1.7 & 1.6 & 1.6 & & & & 1.6+1-0.01 \\ 5 & 1.6 & 1.6 & 1.6 & 1.5 & 1.5 & & 1.6+1-0.07\end{array}$

Recycle Solid /mf Coal Ratio, W\%MF Coal

Operating Day

Conditions

$\begin{array}{cccccccc}1 & 2 & 3 & 4 & 5 & 6 & 7 & \text { Average } \\ 0.0 & 6.1 & 5.2 & 6.5 & 19.1 & 22.7 & & 9.9+1-8.9 \\ 17.5 & 25.0 & 18.5 & 18.3 & 21.3 & 20.0 & 18.7 & 19.9+1-2.6 \\ 19.3 & 19.4 & 17.1 & 21.7 & & & & 19.4+1-1.9 \\ 21.2 & 21.6 & 19.8 & & & & & 20.9+1-1.0 \\ 20.4 & 22.6 & 20.0 & 15.6 & 17.9 & & & 19.3+1-2.7\end{array}$




\section{Table 9. Composition of Recycle Stream}

$\begin{array}{llllll}\text { Conditions: } & 1 & 2 & 3 & 4 & 5\end{array}$

Recycle Stream Composition, W\% mf coal

\begin{tabular}{|c|c|c|c|c|c|}
\hline PFL & 108 & - & - & - & - \\
\hline Agglomerating Oil & -• & 35.1 & 34.3 & 32.8 & - \\
\hline VSOH(IBP $\left.-413^{\circ} \mathrm{C}\right)$ & -- & 11.8 & - & -- & 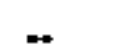 \\
\hline $\begin{array}{l}\text { VSOH }_{2}\left(343^{\circ} \mathrm{C}+\right) \\
\left.\text { VSOH (DW-HT, } 343^{\circ} \mathrm{C}\right)\end{array}$ & - & - & 9.85 & 16.6 & $\overrightarrow{8872}$ \\
\hline $\operatorname{VSB}\left(413^{\circ} \mathrm{C}+\right)$ & 28,4 & 84.4 & 84.8 & 81.7 & 88.72 \\
\hline $\operatorname{VSB}\left(524^{\circ} \mathrm{C}+\right)$ & & & & & 28.6 \\
\hline $\mathrm{PFC}$ & $26.7^{*}$ & 35.0 & 34.2 & 33.0 & 33.2 \\
\hline Total & 163 & 166 & 163 & 164 & 151 \\
\hline
\end{tabular}

Distribution, W\% mf coal

$\begin{array}{lccccc}\text { IBP-260 } & & & \\ & 2.8 & 1.1 & 0.4 & 0.1 & 0.3 \\ 260-343^{\circ} \mathrm{C} & 16.0 & 7.3 & 4.9 & 3.1 & 6.1 \\ 343-454^{\circ} \mathrm{C} & 54.5 & 70.9 & 68.6 & 74.1 & 83.1 \\ 454-524^{\circ} \mathrm{C} & 22.5 & 28.8 & 27.3 & 26.2 & 11.5 \\ \text { Solid Free 524. } 5+ & 44.5 & 39.0 & 40.3 & 40.8 & 31.6 \\ \text { Unconverted Coal } & 9.0 & 6.1 & 7.7 & 7.0 & 7.6 \\ \text { SO, Free Ash } & 13.7 & 13.2 & 14.0 & 12.8 & 10.3 \\ \text { Total } & 163 & 166 & 163 & 164 & 151 \\ & & & & & \\ \text { OM\&Ash/mf coal } & 0.227 & 0.193 & 0.217 & 0.198 & 0.179\end{array}$

* Toluene-extracted PFC 


\section{Table 10. Summary of Process Performance}

DATE
PERIOD
COA Type or Bag \#'s
CONGITION

$\begin{array}{cccc}04 / 24 / 96 & 0430 / 96 & 05 / 01 / 96 & 05 / 05 / 96 \\ 6 & 12 & 13 & 17 \\ \text { Row Cool } & 0 A 4 C 5 \& C 6 & 06 \& C 7 & C 88 C 9 \\ 1 & 2 & 2 & 3\end{array}$
05108/96
20
$\mathrm{Cg} \mathrm{Cl}_{1}$
4
05/13/96
25
Rew Coal
5

NET NORMALIZED YIELDS, W\% maf coal

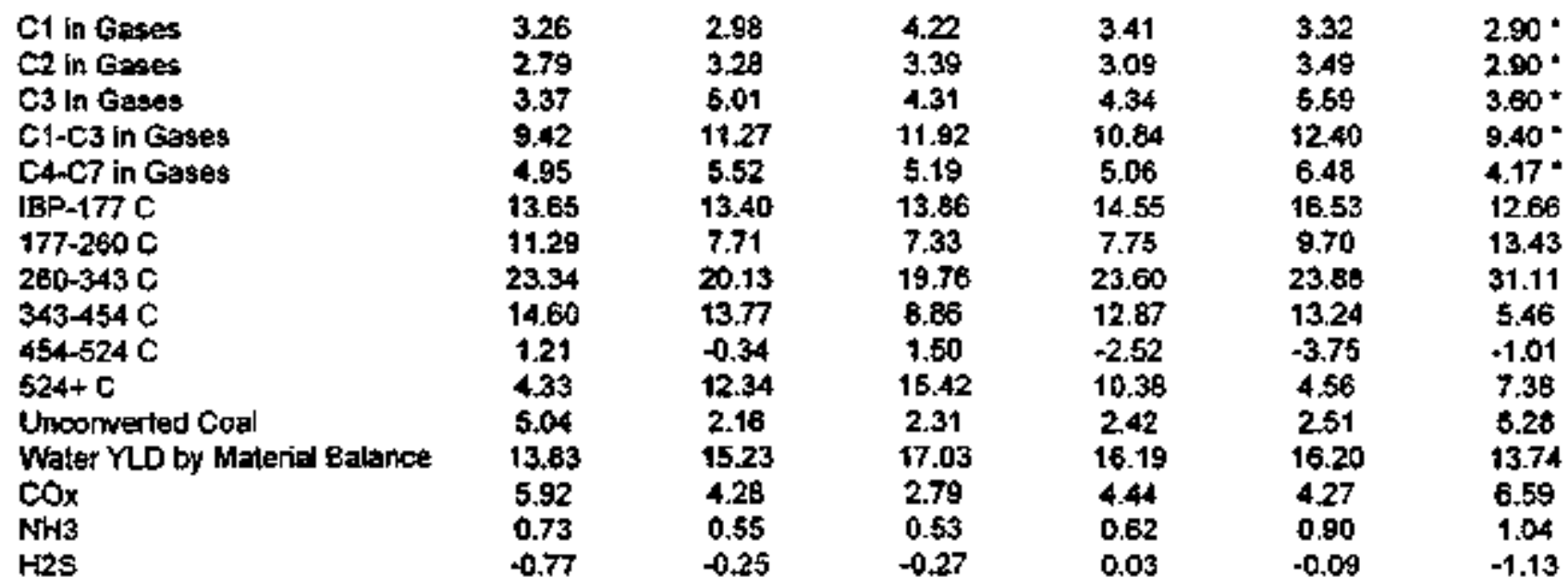

\section{PROCESS PERFORMANCE, W\% maf coal}

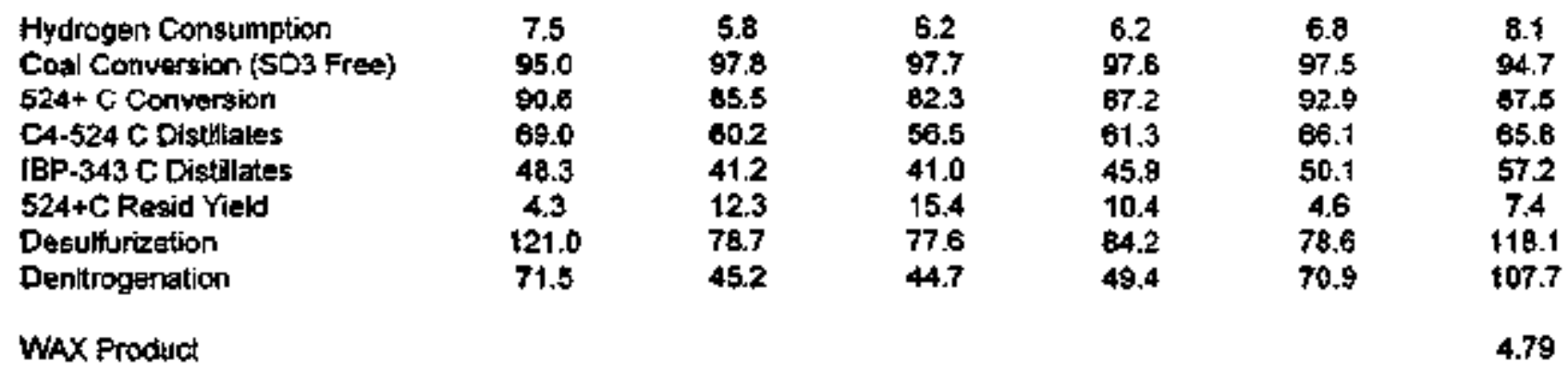

\section{PROCESS CONDITIONS}

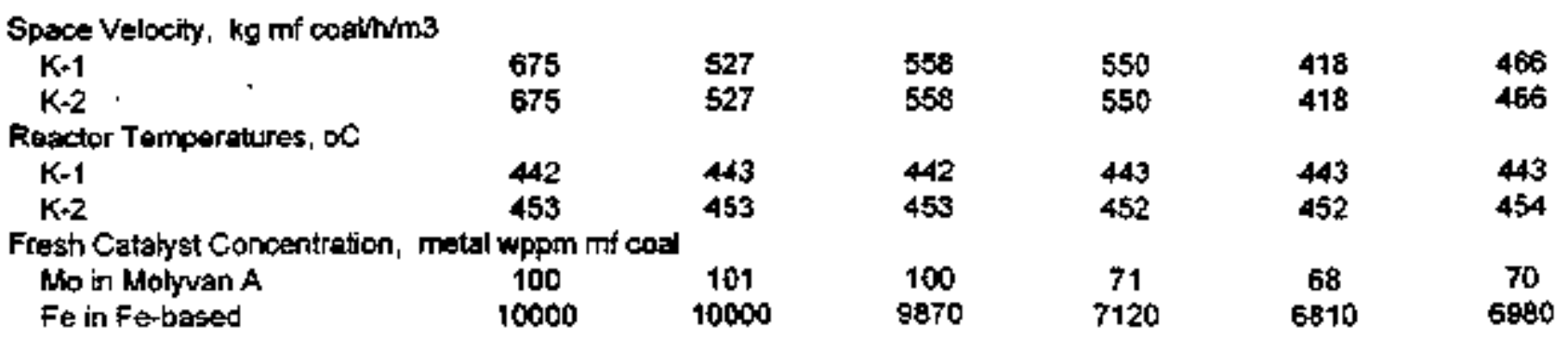

- Not including small quantitles produced in DWVSOH hydrotreating. 


\section{Table 11. First Stage Performance}

Conditions

Cosl Conversion

lst stage

Two stage

524 $^{\circ} \mathrm{C}+$ Resid Conversion

1st stage

Two stage

Gas Yield
1

94.2

95.0

46.2

90.6

4.84

2.84

5.32
2

3

45

5

$\mathrm{C}_{4}-\mathrm{C}_{7}$

$\mathrm{COx}$ $\begin{array}{llll}94.3 & 96.3 & 96.9 & 94.4\end{array}$

$\begin{array}{llll}97.8 & 97.6 & 97.5 & 94.7\end{array}$

Note: All values are on W\% maf coal basis. 
Table 12. Properties of Second Stage Separator Overhead

\begin{tabular}{|c|c|c|c|c|c|c|c|}
\hline Conditions & $\mathbf{t}$ & 1 & 2 & 2 & 3 & 4 & $\mathbf{s}$ \\
\hline Periods & 5 & 6 & 12 & 13 & 17 & 20 & 25 \\
\hline Gravity, ${ }^{\circ} A P I$ & 33.9 & 34.8 & 41.2 & $4] .8$ & 41.9 & 40.5 & 38.3 \\
\hline IBP, 'C & 45 & 45 & 38 & 43 & 49 & 45 & 90 \\
\hline $\mathrm{FBP},{ }^{\circ} \mathrm{C}$ & 392 & 401 & 390 & 399 & 377 & 377 & 380 \\
\hline \multicolumn{8}{|l|}{ Dlemental Analysis } \\
\hline Carbon, W\% & 86.99 & 87.28 & 86.06 & 86.19 & 86.19 & 85.53 & 86.74 \\
\hline Hydrogen, W\% & 12.48 & 12.15 & 12.97 & 13.02 & 13.09 & 12.84 & 12.79 \\
\hline Sulfur, ppm & 1260 & 1380 & 1410 & 1080 & 1080 & 1100 & 1150 \\
\hline Nitrogen, ppm & 1190 & 1950 & 1130 & 960 & 990 & 960 & 1070 \\
\hline H/C Ratio & 1.72 & 1.67 & 1.81 & 1.81 & 1.82 & 1.80 & 1.77 \\
\hline \multicolumn{8}{|c|}{ ASTM D-86 Distillation, Composition, W\% } \\
\hline IBP-177 $\mathrm{C}$ & 38.0 & 36.3 & 48.6 & 48.7 & 49.6 & 39.1 & 39.3 \\
\hline $177-260^{\circ} \mathrm{C}$ & 21.7 & 22.9 & 21.5 & 20.5 & 20.5 & 28.6 & 21.1 \\
\hline $260-343^{\circ} \mathrm{C}$ & 26.3 & 27.6 & 17.0 & 16.9 & 17.0 & 23.5 & 26.3 \\
\hline $343^{\circ} \mathrm{C}+$ & 13.0 & 12.2 & 11.7 & 11.6 & 12.0 & 7.0 & 12.8 \\
\hline LOSS & 1.0 & 1.0 & 1.2 & 2.30 & 0.9 & 0.5 & 0.5 \\
\hline
\end{tabular}


Table 13. Properties of Pressure Filter Liquid and Vacuum Still Overhead

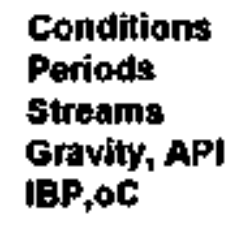

Elemental Analysis, $W \%$

Caton

Hydragen

Sulfut

Nitrogen

H/C ratko

AsTM D-1160 Distillatlon,W\%

$1 \mathrm{BP}-3430 \mathrm{C}$

$343-4540 C$

454-6240C

$52406+$

Loss

\section{On 6240C+ Residutum}

Cyclohexane insolubles, w\%

Toluene insoluble, W\%

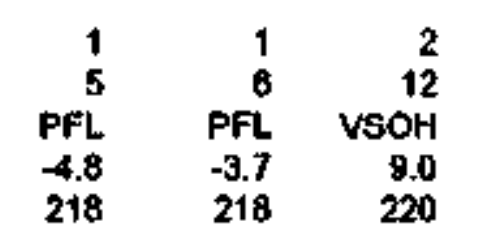

2
13
VSOH

VSOH1 $^{3}$ VSOH2

20

$\begin{array}{lllll}13.8 & 13.8 & 10.2 & 6.6\end{array}$

VSOH1

5

25

VSOH2

7.2

88.22

88.89

B7.83

\subsection{4}

9.20

1.020

0.714

9.12

0.216

0.800

80.55

9.78

0.146

89.53

227

262

16.2
180

318

$1.03 \quad \mathbf{1 0 3} \quad 1.2$

1.26

0.316

0.166

87.93

89.16

89.03

89.76

9.248 .81

0.141

10.74

0.115

9.30

0.116

0.205

$1.36 \quad 1.23$

1.26

1.19

1.45

1.24

$13.34 \quad 17.43 \quad 37.33$

53.60

47.09

12.28

26.68

40.47

61.98

46.00

82.55

35.90

63.12

54.25

45.65

9.71

90.00

64.27

33.13

260

2.60
0.00

10.20

$\begin{array}{lll}12.65 & 0.40 & 0.00 \\ 28.91 & 0.00 & 0.00\end{array}$

0.00

0.69

0.00

0.00

0.00

0.00

1.60

5.55

2.55

0.10

Nole: VSOH1 represents IBP-3430C fraction of VSOH; VSOH2 represents $3430 C+$ fraction of VSOH used in recycle. 
Table 14. Properties of Vacuum Still Bottoms (VSB)

$\begin{array}{lccccccc}\text { Conditions } & 1 & 1 & 2 & 2 & 3 & 4 & 5 \\ \text { Periods } & 5 & 6 & 12 & 13 & 17 & 20 & 25 \\ \text { Cut Point, }{ }^{\circ} \mathrm{C} & 399 & 399 & 413 & 413 & 413 & 413 & 524 \\ \text { Gravity }{ }^{\circ} \text { API } & \text { N/A } & -8.5 & -9.6 & -7.5 & -8.2 & -8.6 & -15.6 \\ \text { IBP, }{ }^{\circ} \text { C } & \text { N/A } & 388 & 393 & 373 & 373 & 389 & 518 \\ \text { Elemental Analysis } & & & & & & & \\ \quad \text { Carbon, W\% } & 85.19 & 85.97 & 88.93 & 89.10 & 89.20 & 89.60 & 89.70 \\ \text { Hydrogen, W\% } & 6.32 & 6.38 & 6.92 & 7.34 & 7.22 & 7.01 & 5.51 \\ \text { Sulfur, W\% } & 1.81 & 1.49 & 0.34 & 0.35 & 0.22 & 0.1 & 0.258 \\ \text { Nitrogen, W\% } & 0.91 & 1.16 & 1.15 & 1.12 & 1.18 & 1.0 & 1.41^{\circ} \\ \text { H/C Ratio } & 0.89 & 0.89 & 0.93 & 0.99 & 0.97 & 0.94 & 0.74\end{array}$

ASTM D-1160 Distillation, Composition, W\%

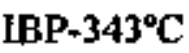

$343-454^{\circ} \mathrm{C}$

$4 \$ 4-\$ 24^{\circ} \mathrm{C}$

$524^{\circ} \mathrm{C}+$

LOSS
\end{abstract}

$>33.56^{*}$
46.44

On $524^{\circ} \mathrm{C}+$ Residuum:

Cyclohexane Insols, w\%

Toluene Insolubles, W\%

$\begin{array}{cccccc}0.0 & 0.0 & 0.0 & 0.0 & 0.0 & 0.0 \\ 31.84 & 34.20 & 41.63 & 39.20 & 36.58 & 0.0 \\ 21.53 & 22.48 & 19.11 & 18.29 & 18.33 & 2.29 \\ 46.30 & \mathbf{4 2 . 8 1} & 38.91 & 42.07 & \mathbf{4 4 . 7 4} & 97.05 \\ 0.33 & 0.51 & 0.35 & 0.44 & 0.35 & 0.66\end{array}$

Note: The amount of sample was not enough for D1160 distillation; $524^{\circ} \mathrm{C}+$ resid content was obtained from TGA. 
Tabje 15. Properties of Unrefined Wax Product

Periods

Elemental Analysis, W\%

Carbon

Hydrogen

Sulfur

Nitrogen

H/C Ratjo
86.75

12.22

Product Distribution, W\%

$\mathrm{C}_{1 \mathrm{~T}} \mathrm{C}_{22}$

$\mathrm{C}_{21}+\mathrm{C}_{30}$

$\mathrm{C}_{31}-\mathrm{C}_{36}$

$524^{\circ} \mathrm{C}+$ Resid Content, W\%
22

0.33

0.32

1.69

23

24

25

$\begin{array}{rrr}84.28 & 81.47 & 85.86 \\ 12.66 & 13.09 & 13.22 \\ 0.37 & 0.87 & 0.31 \\ 0.25 & 0.20 & 0.21 \\ 1.80 & 1.93 & 1.85\end{array}$

24.8

71.9

3.3

1.49

0.28

4.39

3.31 


\section{Table 16. Properties of Pressure Filter Cake}

Conditions

Poriods

Toluene Extracted

$\begin{array}{rrrrrrr}1 & 1 & 2 & 2 & 3 & 4 & 5 \\ 5 & 6 & 12 & 13 & 17 & 20 & 25 \\ \text { Yes } & \text { Yes } & \text { No } & \text { No } & \text { No } & \text { No } & \text { No }\end{array}$

Elemental Anabsis, W\%, ath-free basis

\section{Carbon \\ Hydrogen \\ Sulitur}

Nitrogen

HC

Composition, W\% PFC

Quinoline Insolubles

Ash

Sultur in QI Ash, W\% Ash

ASTM Ash

Sulur th ASTM Ash, W\% Ash

$\begin{array}{rrrrrrr}70.04 & 61.95 & 60.56 & 83.96 & 00.65 & 01.43 & \mathbf{6 4 . 3 1} \\ 3.72 & 3.31 & 5.66 & 5.78 & 5.66 & 5.89 & 5.96 \\ 14.03 & 7.52 & 12.64 & 10.87 & 11.05 & 9.72 & 4.60 \\ 1.15 & 0.74 & 0.85 & 4.22 & 0.88 & 0.72 & 0.85 \\ 0.63 & 0.64 & 0.84 & 0.83 & 0.84 & 0.87 & 0.85\end{array}$

$\begin{array}{rrrrrrr}93.90 & 85.21 & 58.94 & 55.24 & 63.45 & 59.96 & 53.92 \\ 67.72 & 62.58 & 40.31 & 37.68 & 40.94 & 39.44 & 40.27 \\ 10.00 & 10.00 & 3.22 & 3.91 & 3.41 & 3.29 & 10.80 \\ & & & & & & \\ 80.56 & 63.44 & 45.02 & 40.97 & 43.06 & 41.78 & 40.15 \\ 7.34 & 7.48 & 3.22 & 3.00 & 2.02 & 2.85 & 9.00\end{array}$


Table 17. Properties of Toluene-Extracted Pressure Filter Cake

Conditlons

Pertods

Elemental Analyals, WH, ash-free basis
5

1
6

$\mathbf{2}$

2

$\begin{array}{rrr}3 & 4 & 5 \\ 17 & 20 & 25\end{array}$

Carbon
Hydrogen
Sulfur
Naroger
Hoc

Composition, W\% PFC

Quinoline Insolubles

Ash

Sulfur in Ol Ash, W\% Ash

\section{ASTM Ash}

Sulfur in ASTM Ash, W\% Ash

$\begin{array}{rrrrrrr}70.04 & 61.95 & 65.54 & 64.35 & 65.70 & 72.85 & 74.08 \\ 3.72 & 3.31 & 2.84 & 2.78 & 2.72 & 3.52 & 3.98 \\ 16.70 & 11.68 & 29.25 & 28.04 & 26.14 & 23.09 & 7.75 \\ 1.15 & 0.74 & 0.11 & 0.17 & 0.00 & 0.65 & 0.85 \\ 0.63 & 0.64 & 0.52 & 0.52 & 0.5 & 0.58 & 0.64\end{array}$

$\begin{array}{rrrrrrr}93.90 & 85.21 & 96.23 & 95.45 & 90.04 & 95.62 & 76.86 \\ 67.72 & 62.58 & 61.79 & 64.68 & 65.72 & 61.00 & 55.89 \\ 10.00 & 10.00 & 3.40 & 4.00 & 3.66 & 2.73 & 9.64 \\ & & & & & & \\ 80.55 & 63.44 & 63.76 & 63.70 & 63.62 & 63.10 & 50.47 \\ 7.34 & 7.48 & 2.66 & 2.38 & 2.34 & 2.67 & 9.02\end{array}$


Table 18. Properties of First Stage Separator Overhead

\begin{tabular}{|c|c|c|c|c|c|}
\hline Conditions & $\mathbf{1}$ & 2 & 3 & 4 & 5 \\
\hline Periods & 6 & 13 & 17 & 20 & 25 \\
\hline Gravity, ${ }^{\bullet A P I}$ & 28.4 & 31.8 & 31.6 & 28.1 & 29.1 \\
\hline IBP, ${ }^{\circ} \mathrm{C}$ & 54 & 54 & 62 & 58 & 55 \\
\hline FBP, ${ }^{\circ} \mathrm{C}$ & 404 & 411 & 372 & 383 & 380 \\
\hline \multicolumn{6}{|c|}{ Elemental Anahysis,W\% } \\
\hline Carton & 84.39 & 83.03 & 84.19 & 84.24 & 84.81 \\
\hline Hydrogen & 11.21 & 11.54 & 11.74 & 11.29 & 11.43 \\
\hline Sulfur & 0.209 & 0.174 & 0.166 & 0.149 & 0.287 \\
\hline Nitrogen & 0.428 & 0.450 & 0.431 & 0.423 & 0.311 \\
\hline H/C Ratio & 1.59 & 1.67 & 1.67 & 1.61 & 1.62 \\
\hline
\end{tabular}

ASTM D-86 Distillation, Composition, W\%

$\begin{array}{lrrrrr}\text { IBP- } 177^{\circ} \mathrm{C} & 37.3 & 42.8 & 41.9 & 34.6 & 35.1 \\ 177-260^{\circ} \mathrm{C} & 26.2 & 22.8 & 23.7 & 25.8 & 19.9 \\ 260-343^{\circ} \mathrm{C} & 21.4 & 17.8 & 17.4 & 22.7 & 16.2 \\ 343^{\circ} \mathrm{C}+ & 13.8 & 15.7 & 16.3 & 16.2 & 28.1 \\ \text { LOSS } & 1.3 & 0.9 & 0.7 & 0.7 & 0.7\end{array}$


Table 19. Properties of First Stage Sample-Pressure Filter Liquid

\begin{tabular}{|c|c|c|c|c|c|}
\hline Conditions & $\mathbf{I}$ & 2 & 3 & 4 & 5 \\
\hline Periods & 6 & 13 & 17 & 20 & 25 \\
\hline Gravity ${ }^{\circ} \mathrm{API}$ & -4.2 & -2.0 & -3.4 & -10.5 & -3.2 \\
\hline IBP, ${ }^{\circ} \mathrm{C}$ & 245 & 246 & 255 & 234 & 257 \\
\hline \multicolumn{6}{|c|}{ Efemental Analysis, W\% } \\
\hline Carbon & 88.32 & 88.11 & 88.65 & 88.86 & 89.41 \\
\hline Hydrogen & 7.56 & 7.98 & 7.77 & 7.65 & 7.59 \\
\hline Sulfur & 0.65 & 0.36 & 0.42 & 0.38 & 0.19 \\
\hline Nitrogen & 1.16 & 1.11 & 1.03 & 1.05 & 0.92 \\
\hline H/C Ratio & 1.03 & 1.09 & 1.05 & 1.03 & 1.02 \\
\hline
\end{tabular}

ASTM D-1 160 Distillation, Composition, W\%

$\begin{array}{lrrrrr}\text { IBP- }-343^{\circ} \mathrm{C} & 10.31 & 11.27 & 8.15 & 7.22 & 9.07 \\ 343-454^{\circ} \mathrm{C} & 34.64 & 40.01 & 39.82 & 43.43 & 44.46 \\ 454-524^{\circ} \mathrm{C} & 12.86 & 15.27 & 16.59 & 14.14 & 11.25 \\ 524^{\circ} \mathrm{C}+ & 41.61 & 32.36 & 34.54 & 34.70 & 34.66 \\ \text { LOSS } & 0.18 & 1.09 & 0.90 & 0.51 & 0.56\end{array}$

On 524 'C+ Residutum:

$\begin{array}{llllll}\text { Cyclobexane Insols, W\% } & 79.81 & 79.66 & 78.31 & 79.15 & 67.20\end{array}$

$\begin{array}{llllll}\text { Toluene lnsolubles, W\% } & 22.41 & 28.41 & 21.34 & 22.54 & 22.97\end{array}$ 


\section{Table 20. Properties of First Stage Pressure Filter Cake}

Conditions

Periods

Eleraental Analysis, W\%, ash-free basis

Carton

Hydrogen

Sulfur

Nitrogen

Hro

Composition, W\% PFC

Quinoline insolubles

Ash

Sulfur In Ql Ash, W\% Ash

ASTM Ash

Sulfur in ASTM Ash, W\% Ash

TOA S240C Resid, WW $\begin{array}{rrrrr}1 & 2 & 3 & 4 & 5 \\ 6 & 13 & 17 & 20 & 25\end{array}$

$\begin{array}{rrrrr}61.74 & 61.16 & 07.89 & 83.05 & 91.24 \\ 5.90 & 6.00 & 6.33 & 5.61 & 6.73 \\ 6.82 & 9.11 & 5.86 & 6.48 & 3.84 \\ 1.12 & 1.12 & 1.10 & 0.87 & 0.81 \\ 0.87 & 0.89 & 0.86 & 0.81 & 0.88\end{array}$

$\begin{array}{rrrrr}\mathbf{5 8 . 3 0} & 58.24 & 61.48 & 61.74 & 56.32 \\ \mathbf{4 4 . 5 6} & \mathbf{4 1 . 1 4} & \mathbf{4 5 . 6 0} & 44.50 & 40.98 \\ 10.50 & 5.14 & 4.90 & 4.40 & 9.10 \\ & & & & \\ \mathbf{4 4 . 5 8} & \mathbf{4 1 . 8 2} & 45.67 & 44.79 & 40.55 \\ \mathbf{9 . 0 9} & \mathbf{4 . 0 4} & \$ .13 & 3.62 & 7.76 \\ 71.56 & 72.88 & 70.81 & 73.34 & 64.95\end{array}$




\section{Table 21. Properties of Dewared and Hydrotreated Solvent}

(Condition 5, Period 25)

\begin{tabular}{|c|c|c|c|c|}
\hline \multirow[t]{2}{*}{ Stream } & \multirow[t]{2}{*}{ vsoH } & \multirow[t]{2}{*}{ Dw-vsoH } & \multicolumn{2}{|c|}{ DW-Hr VsoH } \\
\hline & & & Whole & $343 \times c t$ \\
\hline APl Gravity & 5.0 & 3.7 & 9.9 & 7.2 \\
\hline $\mathrm{IBP},{ }^{\circ} \mathrm{C}$ & 230 & 253 & 180 & 318 \\
\hline \multicolumn{5}{|c|}{ Elemental Analysis, W\% } \\
\hline Carbon & 89.51 & 88.95 & 89.54 & 89.76 \\
\hline Hydrogen & 8.68 & 8.34 & 9.74 & 9.30 \\
\hline Sulfur & 0.15 & 0.17 & 0.12 & 0.12 \\
\hline Nitrogen & 0.53 & 0.53 & 0.19 & 0.21 \\
\hline H/C Ratio & 1.16 & 1.13 & 1.31 & 1.24 \\
\hline \multicolumn{5}{|c|}{ ASTM D-1160 Distillation, Composition, W\% } \\
\hline IBP- $343^{\circ} \mathrm{C}$ & 20.48 & 21.81 & 26.64 & 10.20 \\
\hline $343-454^{\circ} \mathrm{C}$ & 71.52 & 72.38 & 66.86 & 81.60 \\
\hline $454.524^{\circ} \mathrm{C}$ & 5.30 & 3.61 & 4.65 & 5.55 \\
\hline $524^{\circ} \mathrm{C}+$ & 2.60 & 1.91 & 1.77 & 2.55 \\
\hline Loss & 0.10 & 0.29 & 0.08 & 0.10 \\
\hline
\end{tabular}


Table 22. Analysis of TBP Fractions: Condition 1, Period 5

TBP Distillation

$\mathrm{IBP},{ }^{\circ} \mathrm{C}$

Distribution $\quad$ W\%

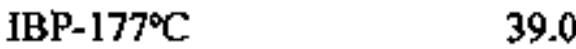

$177-260^{\circ} \mathrm{C} \quad 21.1$

$260-343^{\circ} \mathrm{C} \quad 29.0$

$343^{\circ} \mathrm{C}+\quad 10.5$

LOSS 0.4

API Gravity

54.7

31.0

19.5

11.5

Elemental Analysis, W\%

Carbon

Hydrogen

Sulfur, ppm

Nitrogen, ppm

Bromine No. $[\mathrm{g} / \mathrm{log}]$

Aniline Point, $\left[{ }^{\circ} \mathrm{C}\right]$

Pour Point, $\left[{ }^{\circ} \mathrm{C}\right]$

Flash Point, $\left[{ }^{\circ} \mathrm{C}\right]$

PONA[V\%]

Paraffins

Olefins

Naphthenics

Aromatics
85.19

I4.46

1090

1020

1.05

51

$-62$

$<-18$

51.74

0.50

40.99

6.77
87.96

12.46

1110

1310

2.06

32

$-62$

70

88.90

11.13

1150

1160

1.92

24

$-50$

138
89.77

9.92

1370

1400 
Table 23. Analysis of TBP Fractions: Condition 1, Period 6

TBP Distillation,

$\begin{array}{lr}\text { 1BP, }{ }^{\circ} \mathrm{C} & 42 \\ & \\ \text { Disstibution } & \text { w\% } \\ 1 \mathrm{BP}-177^{\circ} \mathrm{C} & 36.6 \\ 177-260^{\circ} \mathrm{C} & 25.0 \\ 260-343^{\circ} \mathrm{C} & 31.0 \\ 343^{\circ} \mathrm{C}+ & 7.3 \\ \text { LOSS } & 0.1\end{array}$

IBP-177" C $\quad 177-261^{\circ} \mathrm{C} \quad 260-343^{\circ} \mathrm{C} \quad 343^{\circ}+^{\circ} \mathrm{C}$

API Gravity

55.1

28.7

18.4

8.6

Elemental Agalysis, W\%

Carbon
Hydrogen
Sulfur, ppm
Nitrogen, ppm

Bromine No. $(g / 100 \mathrm{~g})$

Aniline Point, $\left[{ }^{\circ} \mathrm{C}\right]$

Pour Point, $\left[{ }^{\circ} \mathrm{C}\right]$

Flash Point, $\left[{ }^{\circ} \mathrm{C}\right]$

PONA[V\%]

Paraffins

Olefins

Napbthenics

Aromatics
84.74

14.33

1100

1220

3.95

51

$-62$

$<-17$
88.94

11.94

1140

1400

14.02

19

$-62$

68

14.46

0.60

41.81

7.01
1.50

38.04

46.0
90.14

9.46

1740

1600

$\begin{array}{ll}10.74 & 9.46 \\ 1340 & 1740 \\ 1400 & 1600\end{array}$

5.61

17

$-52$

138

65.6 
Table 24. Analysis of TBP Fractions: Condition 2, Period 12

TBP Distillation,

$\begin{array}{lr}\text { IBP, }{ }^{\circ} \mathrm{C} & 49 \\ & \\ \text { Distribution } & \underline{\mathrm{W} \%} \\ \text { IBP- } 177^{\circ} \mathrm{C} & 19.6 \\ 177-260^{\circ} \mathrm{C} & 19.9 \\ 260.343^{\circ} \mathrm{C} & 26.6 \\ 343^{\circ} \mathrm{C}+ & 33.6 \\ \text { LOSS } & 0.3\end{array}$

APJ Gravity

IBP- $177^{\circ} \mathrm{C} \quad 177-260^{\circ} \mathrm{C} \quad 260-343^{\circ} \mathrm{C} \quad 343+^{\circ} \mathrm{C}$

55.6

28.0

14.9

7.4

Elemental Analysis, W\%

Carbon
Hydrogen
Sulfur, ppm
Nitrogen, ppm

Bromine No. $[\mathrm{g} / 100 \mathrm{~g}]$

Aniline Point, $\left[{ }^{\circ} \mathrm{C}\right]$

Pour Point, $\left[{ }^{\circ} \mathrm{C}\right]$

Flash Point, [ ${ }^{\circ} \mathrm{C}$ ]

PONA[V\%]
85.16

14.72

1090

990

0.53

54

$-62$

$<-17$

52.54

0.70

41.83

4.93
84.11

11.31

1210

1510

12.6

24

$-46$

51
89.23

9.21

1780

1660

88.23
10.34
1570
1710

21.07
13
-10
134

Olefins

15.10

N/A

35.56

Aromatics

49.34

71.1 
Table 25. Analysis of TBP Fractions: Condition 2, Period 13

TBP Distillation

\begin{tabular}{lr} 
IBP, ${ }^{\circ} \mathrm{C}$ & 39 \\
Distribution & \\
\hline IBP-177\% & \\
$177-260^{\circ} \mathrm{C}$ & 28.6 \\
$260-343^{\circ} \mathrm{C}$ & 18.0 \\
$343^{\circ} \mathrm{C}+$ & 24.0 \\
LOSS & 29.0 \\
& 0.4
\end{tabular}

IRP $-177^{\circ} \mathrm{C} \quad 172-260^{\circ} \mathrm{C} \quad 260-343^{\circ} \mathrm{C} \quad 343+^{\circ} \mathrm{C}$

API Gravity

55.9

28.6

15.6

7.8

Elemental Analysis, W\%

\section{Carbon \\ Hydrogen \\ Sulfur, ppm \\ Nitrogen, ppIn}

Bromine No. [g/100g]

Aniline Point, ["C]

Pour Point, $\left[^{\circ} \mathrm{C}\right]$

Flash Point, [ $\left.{ }^{\circ} \mathrm{C}\right]$

PONA[V\%]

Paraffins

Olefins

Naphthenics

Aromatics
84.84

14.57

1090

990

0.53

52

$-62$

$<-17$

50.55

0.60

43.98

4.87
87.02

11.81

1230

1590

18.53

24

.51

47

88.17

10.33

1510

1580

20.76

13

.8

138
89.11

9.29

1770

1670
14.35

N/A

36.77

48.88

67.7 
Table 26. Analysis of TBP Fractions: Condition 3, Period 17

TBP Distillation

$\begin{array}{lr}\text { IBP, }{ }^{\circ} \mathrm{C} & 42 \\ \text { Distribution } & \frac{\text { W\% }}{25.1} \\ \text { IBP-177 } \mathrm{C} & 18.9 \\ 177-260^{\circ} \mathrm{C} & 24.8 \\ 260-343^{\circ} \mathrm{C} & 30.9 \\ 343^{\circ} \mathrm{C}+ & 0.3 \\ \text { LOSS } & \end{array}$

$18 \mathrm{P}-177^{\circ} \mathrm{C} \quad 177-260^{\circ} \mathrm{C} \quad 260-343^{\circ} \mathrm{C} \quad 343+^{\circ} \mathrm{C}$

API Gravity

57.2

26.1

14.6

7.8

Elemental Analysis, W\%

Carbon

Hydrogen

Sulfur, ppm

Nitrogen, ppm

Bromine No. $\left[\mathrm{g} / 10 \mathrm{~g}_{\mathrm{g}}\right]$

Aniline Point, [ $\left.{ }^{\circ} \mathrm{C}\right]$

Pour Point, [ [ $\left.{ }^{\circ} \mathrm{C}\right]$

Fiash Point, [ $\left.{ }^{\circ} \mathrm{C}\right]$

PONA[N\%]

Paraffins

Olefins

Naphthentics

Aromatics
84.94

14.70

1090

996

1.07

53

$-62$

$<-17$

$\$ 2.25$

0.60

41.92

5.23
86.24

11.27

1200

1620

33.81

19

$-60$

69

87.88

10.04

1420

1560

18.56

9

$-12$

138
89.16

9.21

1510

1650 
Table 27. Analysis of TBP Fractions: Condition 4, Period 20

\section{TBP Distihation,}

\begin{tabular}{lr} 
IBP, ${ }^{\circ} \mathrm{C}$ & 41 \\
& \\
Distribution & $\frac{\text { w\% }}{27.4}$ \\
\hline IBP-177 & 20.3 \\
$177-260^{\circ} \mathrm{C}$ & 29.4 \\
$260.343^{\circ} \mathrm{C}$ & 22.2 \\
$343^{\circ} \mathrm{C}+$ & 0.7 \\
LOSS &
\end{tabular}

\section{IBP-177 ${ }^{\circ} \mathrm{C} \quad 177-260^{\circ} \mathrm{C} \quad 260-343^{\circ} \mathrm{C} \quad 3434^{\circ} \mathrm{C}$}

API Gravity

55.8

28.4

15.8

6.9

Elemental Analysis, W\%

Carbon
Hydrogen
Sulfur, ppm
Nitrogen, ppm

Bromine No. $[g / 100 \mathrm{~g}]$

Aniline Point, $\left[{ }^{\circ} \mathrm{C}\right]$

Pour Point, $\left[{ }^{\circ} \mathrm{C}\right]$

Flash Point, $\left[{ }^{\circ} \mathrm{C}\right]$

PONA[V\%]

Paraffins

Olefins

Naphthenics

Aromatics

85.0
14.60
1100
972

0.53

51

$-62$

$<-17$
87.19

11.80

1160

1610

19.86

24

$-58$

64

88.44

10.41

1280

1600

19.55

9

$-12$

129
89.47

9.26

1440

1670
$47.61 \quad 13.48$

$0.60 \quad$ N/A

$46.44 \quad 37.95$

$5.35 \quad \mathbf{4 8 . 5 7}$

69.8 
Table 28. Analysis of TBP Fractions: Condition 5, Period 25

\section{TBP Distiliation,}

$\begin{array}{lr}\text { IBP, }{ }^{\circ} \mathrm{C} & 43 \\ \text { Distribution } & \frac{W \%}{26.2} \\ \text { IBP-177 } \\ 177-260^{\circ} \mathrm{C} & 18.2 \\ 260-343^{\circ} \mathrm{C} & 35.0 \\ 343^{\circ} \mathrm{C}+ & 20.6 \\ \text { LOSS } & 0.0\end{array}$

IBP-177 ${ }^{\circ} \mathrm{C} \quad 177-269^{\circ} \mathrm{C} \quad 260-343{ }^{\circ} \mathrm{C} \quad 3434^{\circ} \mathrm{C}$

API Gravity

56.3

30.4

17.6

6.7

Elemental Analysis, W\%

Carbon
Hydrogen
Sulfur, ppm
Nitrogen, ppm

Bromine No. $[\mathrm{g} / 100 \mathrm{~g}]$

Aniline Point, $\left[{ }^{\circ} \mathrm{C}\right]$

Powr Point, $\left[{ }^{\circ} \mathrm{C}\right]$

Flash Point, [ $\left.{ }^{\circ} \mathrm{C}\right]$

PONA[V\%]
84.91

14.63

1090

927

0.27

52

$-62$

$<-17$

51.16

0.60

42.48

5.76

88.09
12.24
1100
1190

89.22

11.11

1110

1340

1.68

18

$-52$

131

$66 \quad 131$

1.60

26

$-62$

0.54

9.48

1150

1440
Paraffins
Olefins
Naphthenics
Aromatics 
Table 29. Phenolic Content of Separator Overiead

\begin{tabular}{llllllll} 
Conditions & 1 & 1 & 2 & 2 & 3 & 4 & 5 \\
Periods & 5 & 6 & 12 & 13 & 17 & 20 & 25 \\
& & \multicolumn{8}{c}{ Phenolic Content, ppm }
\end{tabular}

Water Fraction

First stage

$\mathrm{N} / \mathrm{A}^{*}$

2920

N/A*

3350

3180

3580

4660

Second stage

490

1480

770

470

610

360

120

Ofl Fraction

First stage

N/A*

18600

N/A*

23700

23200

22500

22100

Second stage

440

760

530

480

900

300

250

N/A: Samples were not available 


\section{Table 30. Characterization of Hydrotreater Catalyst}

(Criterion C-411)

$\begin{array}{ll}\text { Catalyst } & \text { Fresh }\end{array}$

Surface Property

BET Surface Area, $\mathrm{m}^{2} / \mathrm{g} \quad 152$

Pore Volume, $\mathrm{ml} / \mathrm{g}$
0.387
In-line HTU

(Spent)

\section{Solvent Hydrotreating}

(Spent)

Elemental Analysis, W\%

Carbon

Hydrogen

Sulfur

Nitrogen
0.17

0.47

0.10

0.04

Metals, W\% Catalyst
2.22

13.01
115

0.153
151

$\mathbf{0 . 3 7 9}$

Mo

1.63

2.18

9.61

0.45

0.44

0.10

0.10

0.49
0.24

12.84 
Table 31. Comparison of Run ALC-1 and CMSL-9

Run No

Conditions

Period

Coal

Space Velocity,

$\mathbf{k g} / \mathbf{h r} / \mathbf{m}^{3}$ mf coal, each stage

Reactor Temperature, ${ }^{\circ} \mathrm{C}$

$\mathrm{K}-1$

K.2

Recycle Streams, W\% mf coal

IBP-343 ${ }^{\circ} \mathrm{C}$

$343-454^{\circ} \mathrm{C}$

454-524 ${ }^{\circ} \mathrm{C}$

Soljd Free $524^{\circ} \mathrm{C}+$

Unconverted Coal

$\mathrm{SO}_{3}$ Free Ash

Recycle/MF Coal

Catalyst Concentration, ppm mf coal

Mo

$\mathrm{Fe}$

Net Normalized Yield, $W \%$ maf coal

$\mathrm{C}_{\mathrm{t}}-\mathrm{C}_{3}$ in Gases

$\mathrm{C}_{4}-\mathrm{C}_{7}$ in Gases

IBP- $177^{\circ} \mathrm{C}$

$177-260^{\circ} \mathrm{C}$

$260-343^{\circ} \mathrm{C}$

$343-454^{\circ} \mathrm{C}$

$454-524^{\circ} \mathrm{C}$

$524^{\circ} \mathrm{C}+$

Unconverted Coal

$\mathrm{H}_{2} \mathrm{O}$

$\mathrm{COx}$

$\mathrm{NH}_{3}$

$\mathrm{H}_{2} \mathrm{~S}$
ALC-1

I

6

Black Thunder

683

442

453

18.8

54.5

22.5

44.5

9.0

13.7

1.63

100

100)(gel)
CMSL-9

6

29

Black Thunder

666

440

449

35.9

66.0

3.3

16.2

5.3

10.8

1.38

100

10000(powder)
9.42

4.95

13.65

11.29

23.34

14.60

1.21

4.33

5.04

13.83

5.92

0.73

$-0.77$
9.23

4.66

7.37

15.64

14.92

12.44

4.01

7.35

4.34

14.96

4.38

0.86

$-0.15$

Process Performance, W\% maf Coal

Hyórogen Consumption

7.5

5.8

Coal Conversion

95.0

96.1

$524^{\circ} \mathrm{C}+$ Conversion

90.6

87.6

C4-524 $4^{\circ} \mathrm{C}$ Distillate

69.0

62.6

$524^{\circ} \mathrm{C}+$ Resid Yıeld 
Table 32

RUN ALC-1 OPERATIONS-STATUS-CLASSIFICATION CHRONOLOGY

\begin{tabular}{|c|c|c|c|c|c|}
\hline \multirow{2}{*}{$\begin{array}{c}\text { Operations } \\
\text { Classification } \\
\text { I.D } \\
\end{array}$} & \multicolumn{2}{|c|}{ Stant } & \multicolumn{2}{|c|}{ End } & \multirow{2}{*}{$\begin{array}{c}\text { Duration, } \\
\text { Hours }\end{array}$} \\
\hline & Time & Date & Time & Date & \\
\hline $\mathbf{S} / \mathbf{U}$ & 1600 & $4 / 15 / 96$ & 1700 & $4 / 16$ & 25 \\
\hline S/D & 1700 & $4 / 16$ & 1800 & $4 / 16$ & 1 \\
\hline DT & 1800 & $4 / 16$ & 1400 & $4 / 17$ & 20 \\
\hline $\mathbf{S} / \mathbf{U}$ & 1400 & $4 / 17$ & 0500 & $4 / 19$ & 39 \\
\hline $1-25$ & 0500 & $4 / 19$ & 0400 & $5 / 14$ & 599 \\
\hline $\mathrm{S} / \mathrm{D}$ & 0400 & $5 / 14$ & 1000 & $5 / 15$ & 30 \\
\hline
\end{tabular}

Table 33

ON-LINE TIME AND DOWN TIME FOR RUN ALC-1

\begin{tabular}{|c|c|c|c|c|}
\hline $\begin{array}{l}\text { Time of } \\
\text { Initial S/U } \\
\text { \& Final } \\
\text { SD. Hours }\end{array}$ & $\begin{array}{c}\text { Time of Intermediate } \\
\text { S/Ds \& S/Us, Hours } \\
\text { (No. of lnt. S/D-S/U) } \\
\text { Hours }\end{array}$ & $\begin{array}{l}\text { Total On- } \\
\text { Line Time, } \\
\text { Hours }\end{array}$ & $\begin{array}{c}\text { Down-Time, } \\
\text { Hours }\end{array}$ & $\begin{array}{c}\text { On-Line } \\
\text { Efficiency } \%\end{array}$ \\
\hline 5 & 40 & 694 & 20 & 97.2 \\
\hline
\end{tabular}

Definitions:

Startup: Time between gas flow initiation and feedstock cut-in during which unit (S/U) temperatures and/or pressures are being increased.

Shutdown: $\quad$ Time between feedstock cut-ous and liquid flow termination during which unit (SID) temperatures and/or pressures are being decreased.

Run-Periods: Time duning which the unit is at run conditions and the operations is identified with a Period number.

On-Line Tine: The sum of S/Us, S/Ds, and Run-Periods.

Down-Time: The tirne duting which gases and liquids are not being charged to the unit. This (DT) is the same as the time between an intermediate shutdown and startup.

On-Line Eficiency=On-Line Time / (On-line Time + Down-Time) 
Figure 1. Simplified Schematic of HTI's Bench Unit

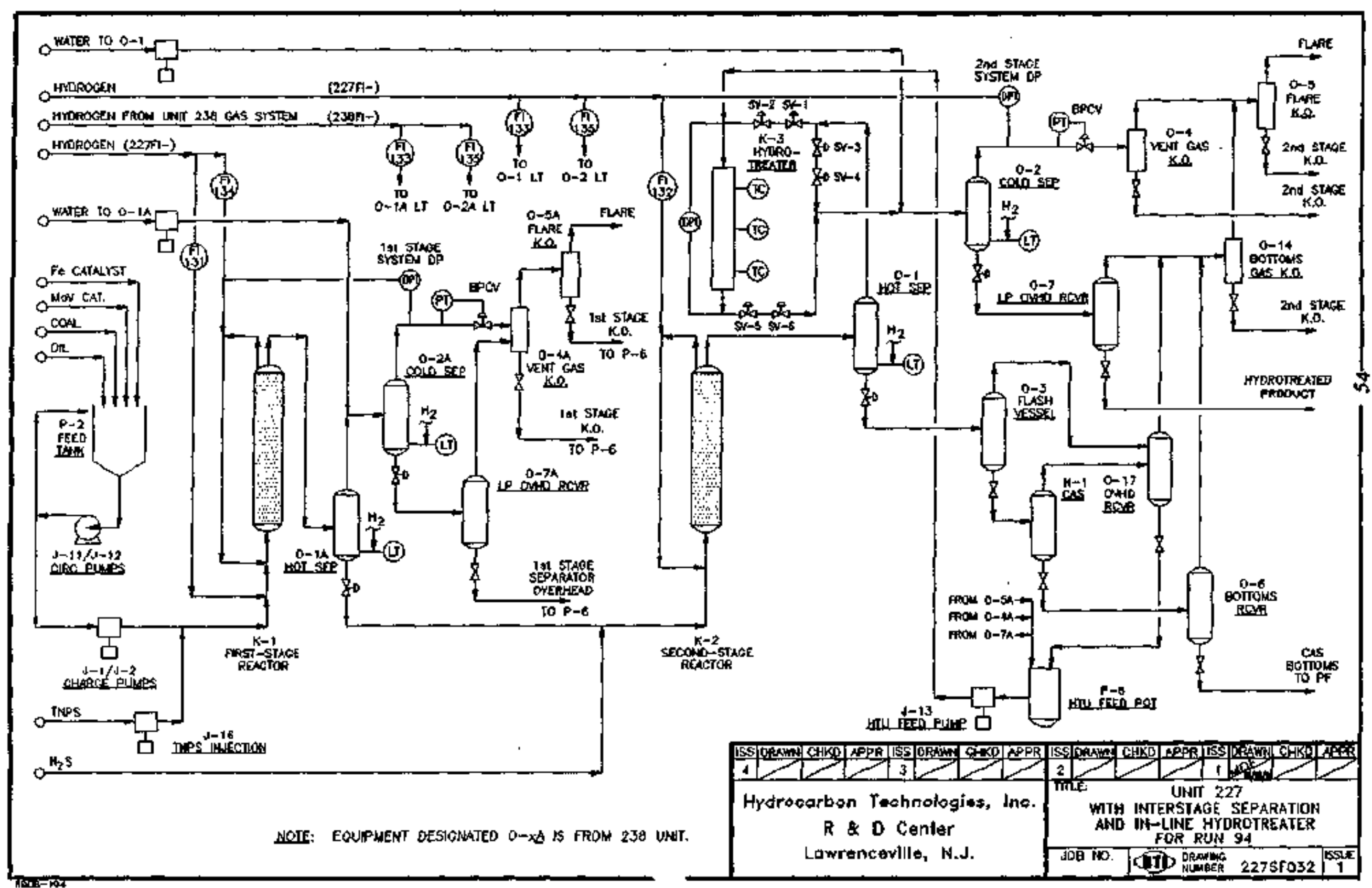


Figure 2

Downstream Product Flow Scheme

Condition 1 (Periods 1-7)
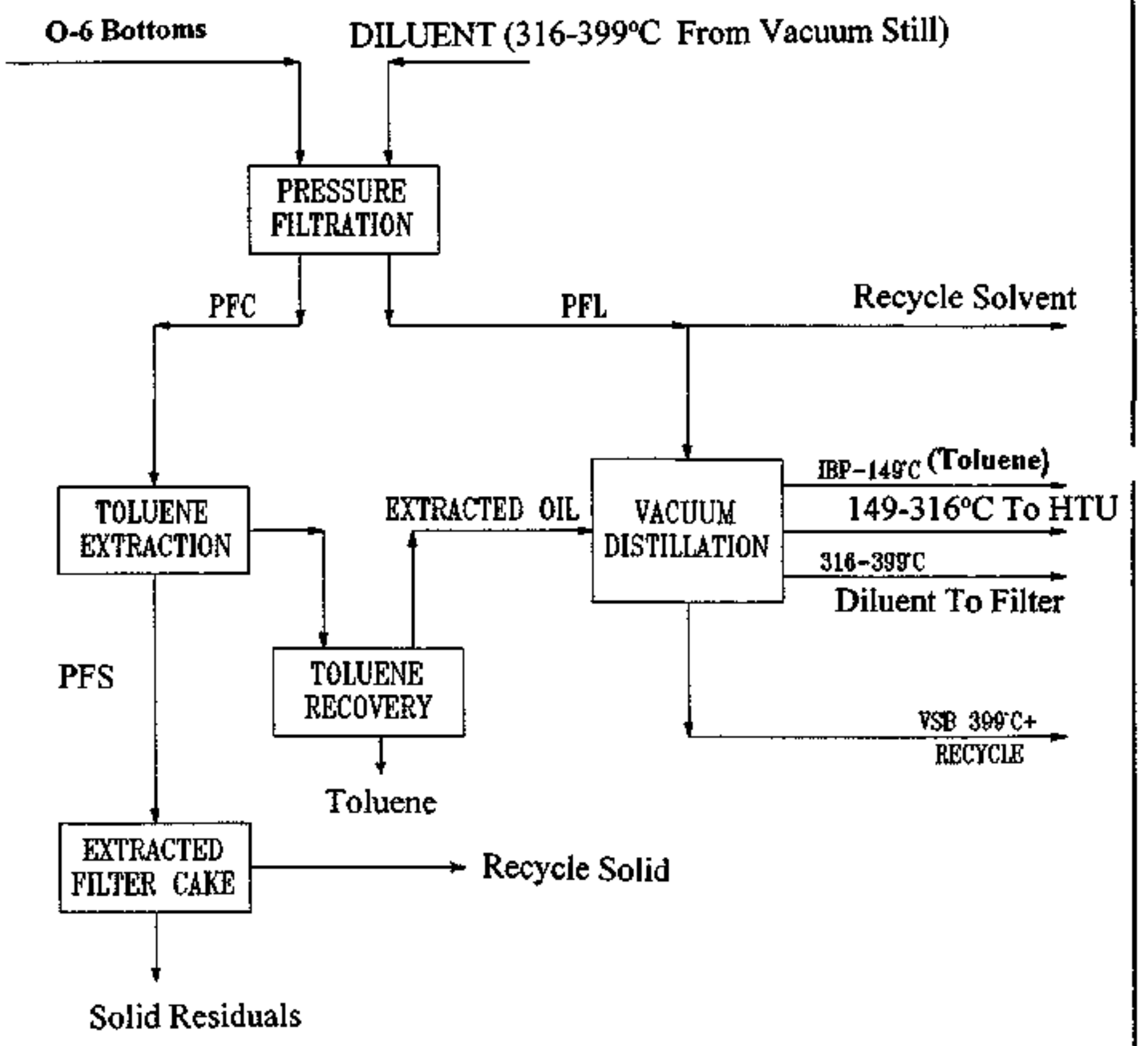
Figure 3

Downstream Product Flow Scheme

Condition 2 (Periods 8-13)

O-6 Bottoms

DILUENT (Toluene Extracted Oil 149-316 $6^{\circ} \mathrm{C}$ )

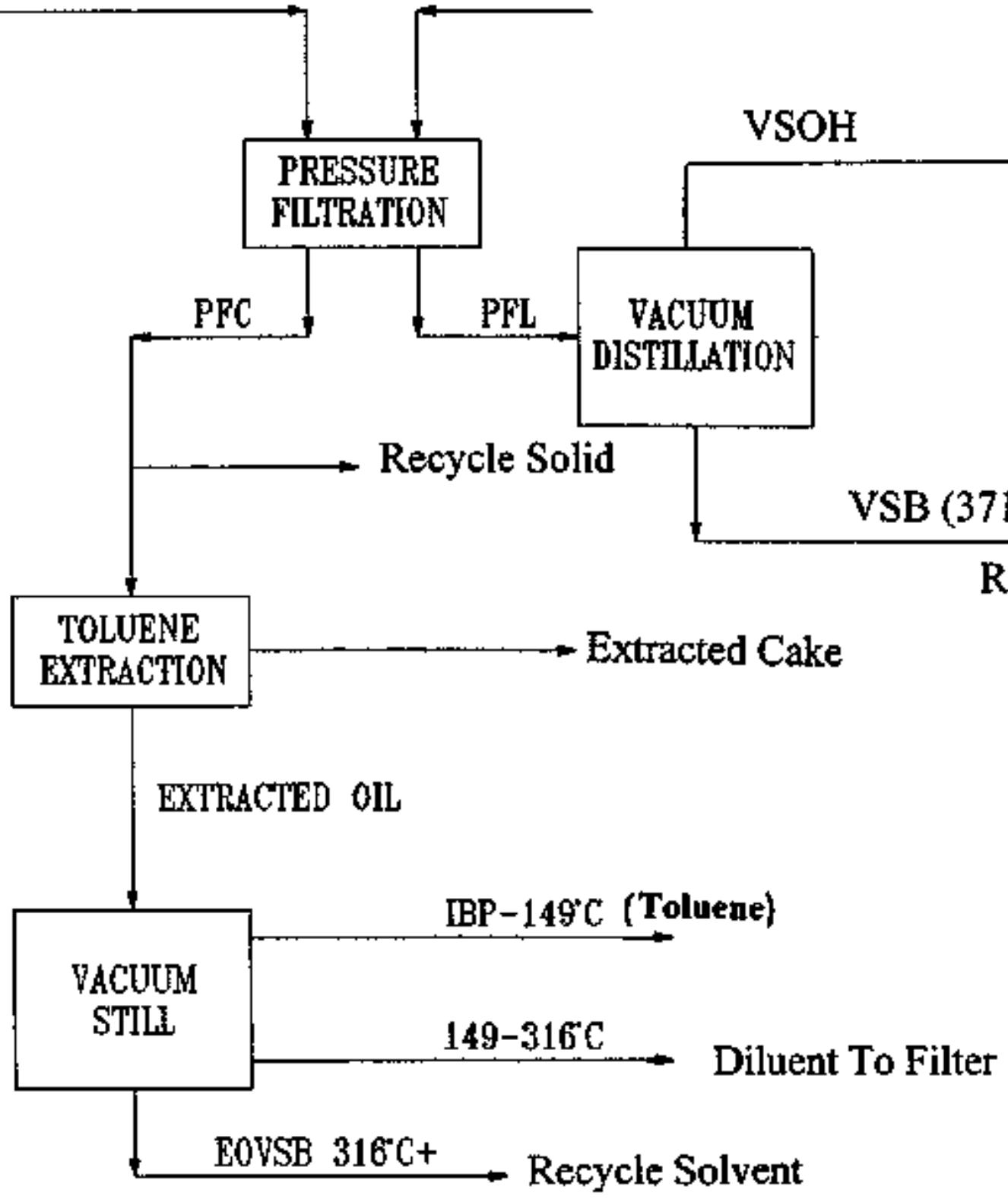


Figure 4

Downstream Product Flow Scheme

Conditions 3\&4 (Periods 14-20)

O-6 Bottoms

DILUENT (149-343ㅇ From Vacuum Still)

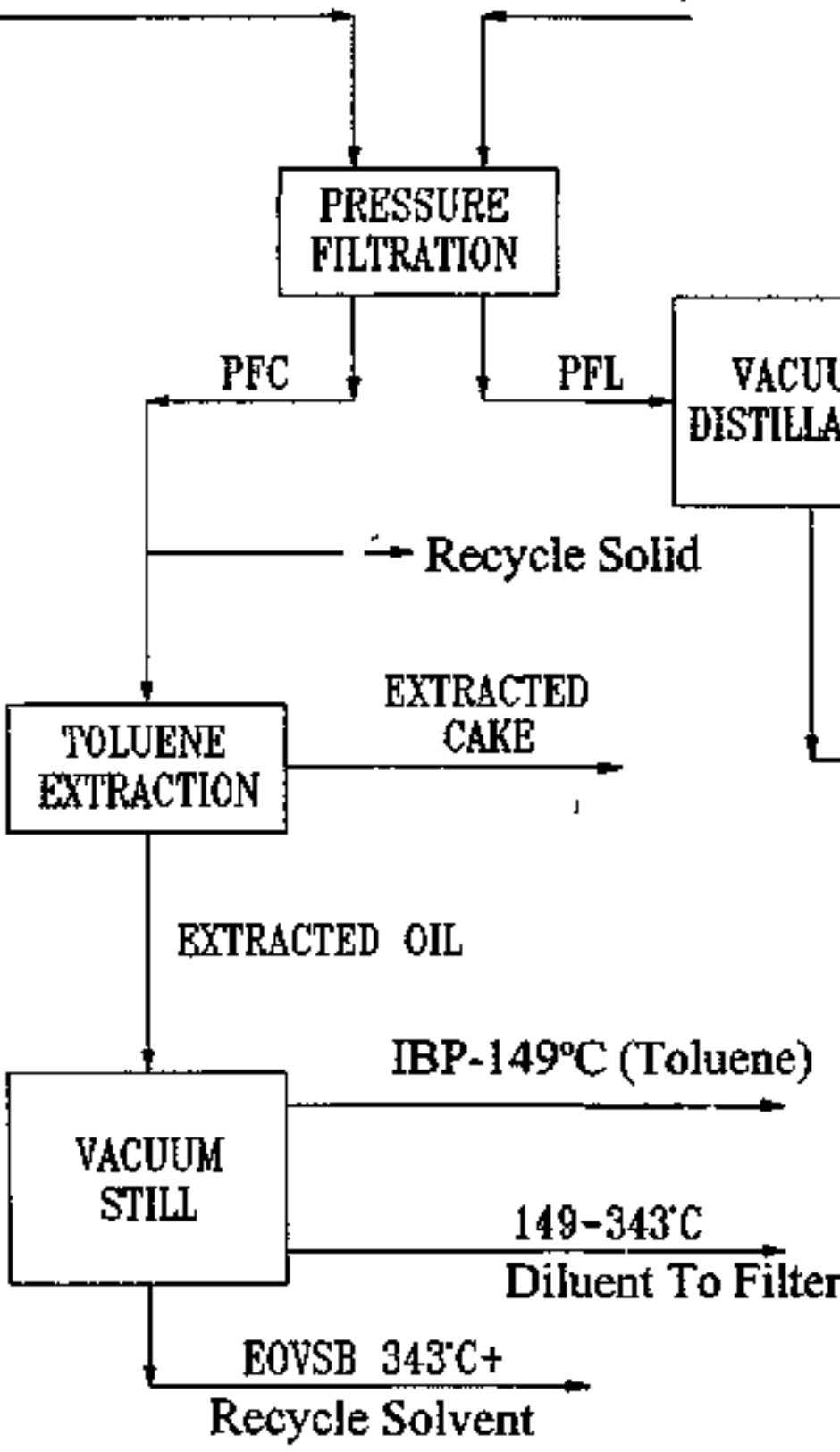




\section{Figure 5}

Downstream Product Flow Scheme Condition 5 (Periods 21-25)

DW-HT VSOH (Product)

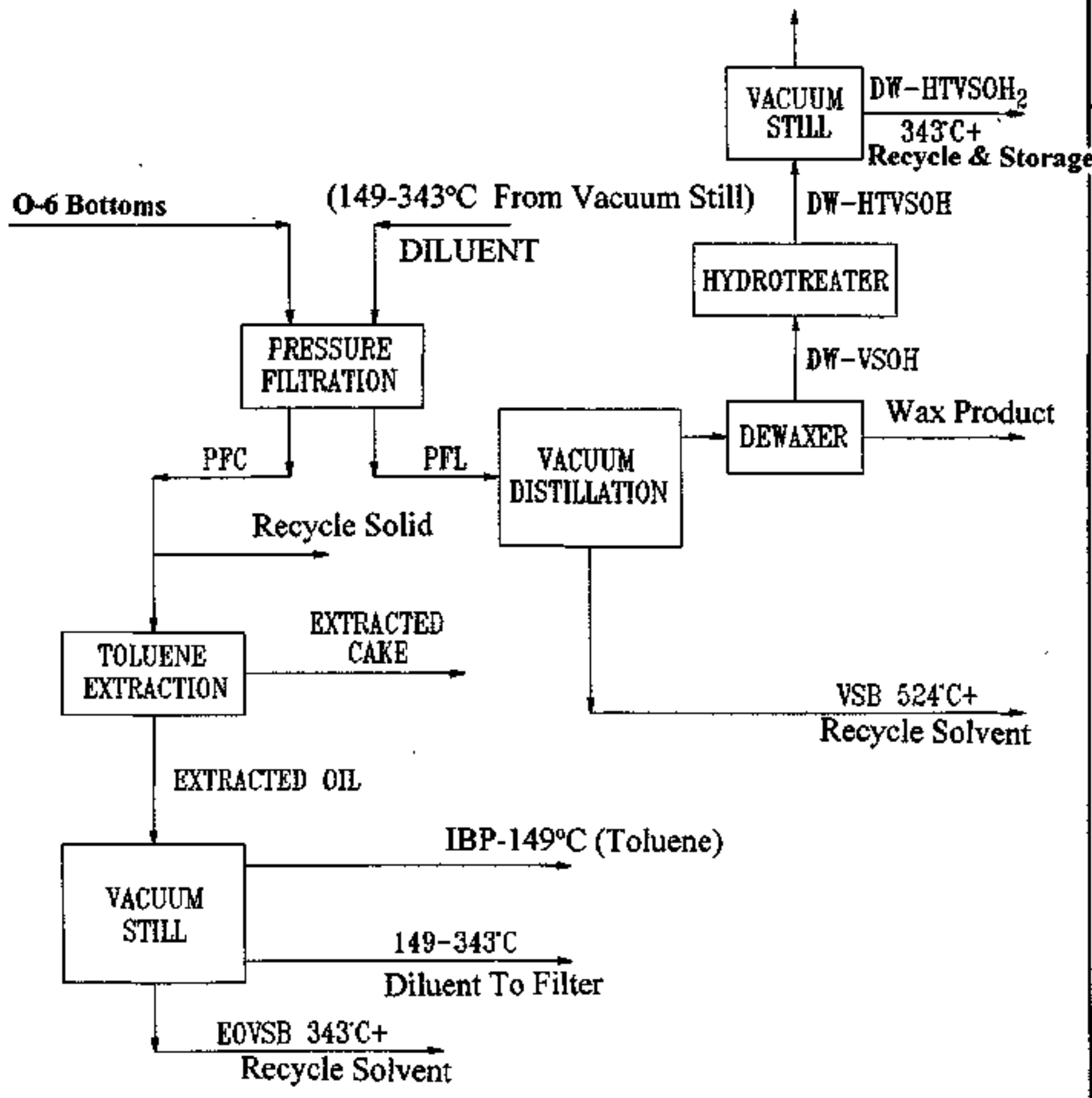




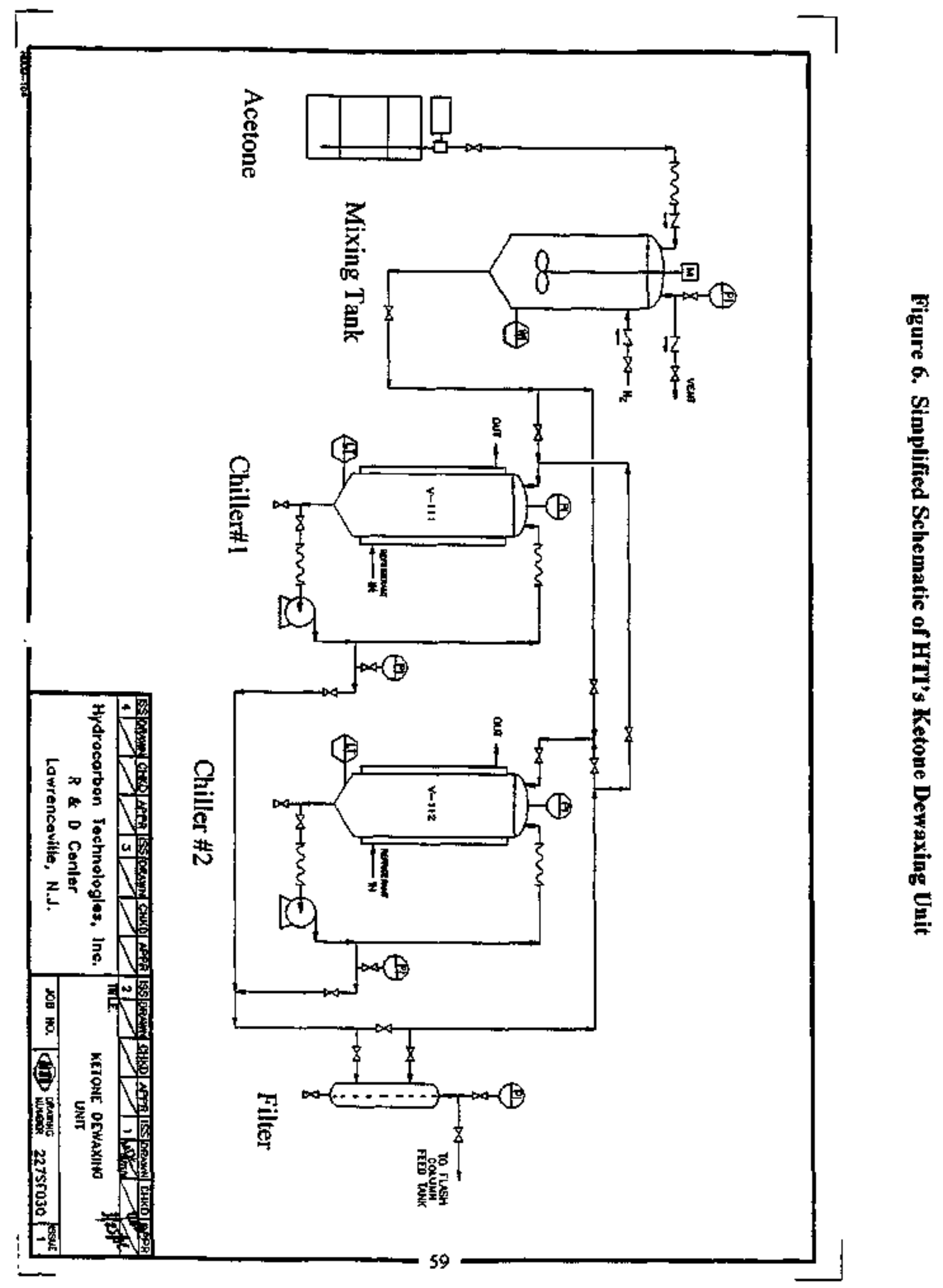


Figure 7

\section{K-1 \& K-2 Temperature}

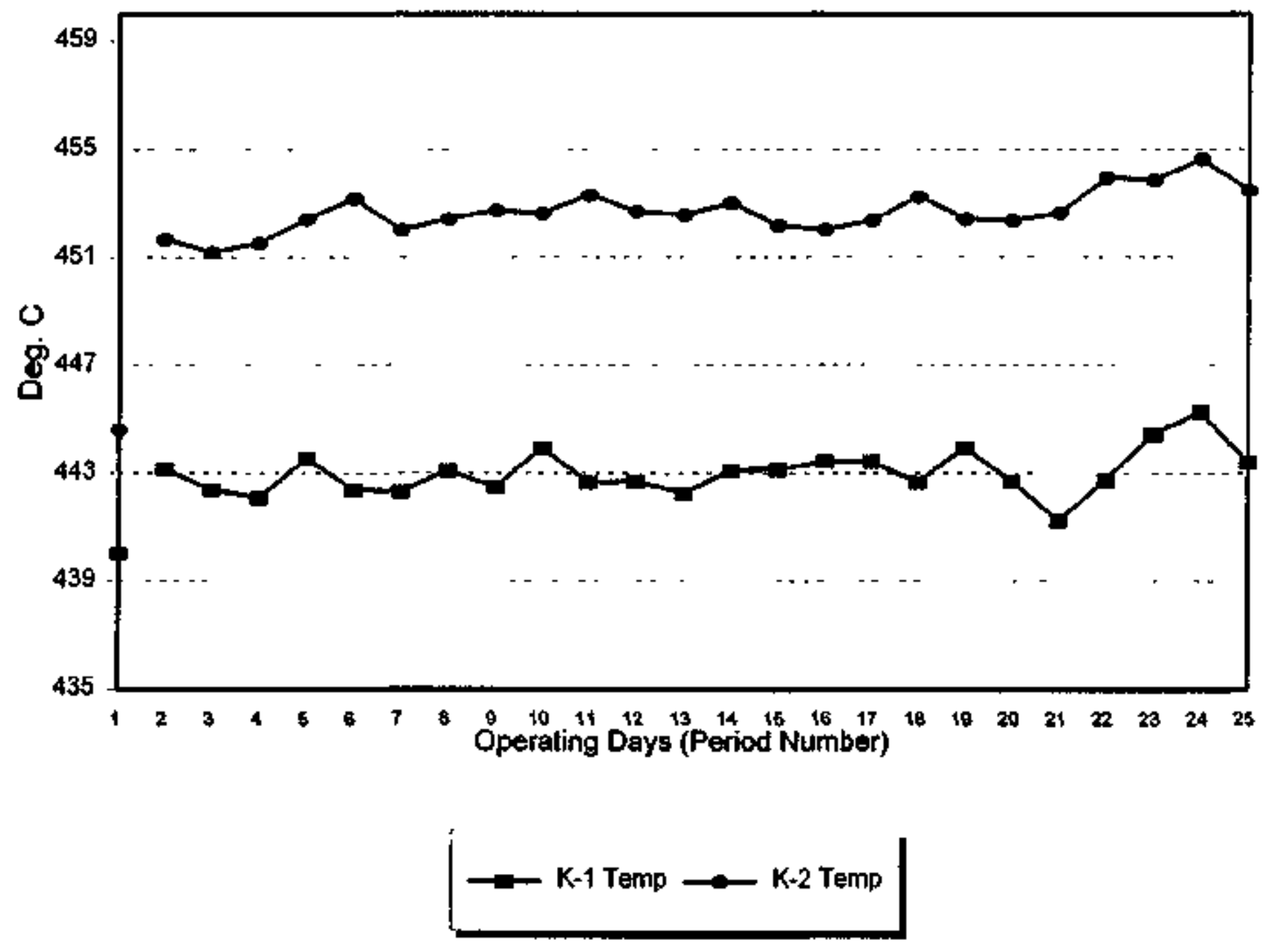


Figure 8

\section{0-1A \& 0-1 Temperature}

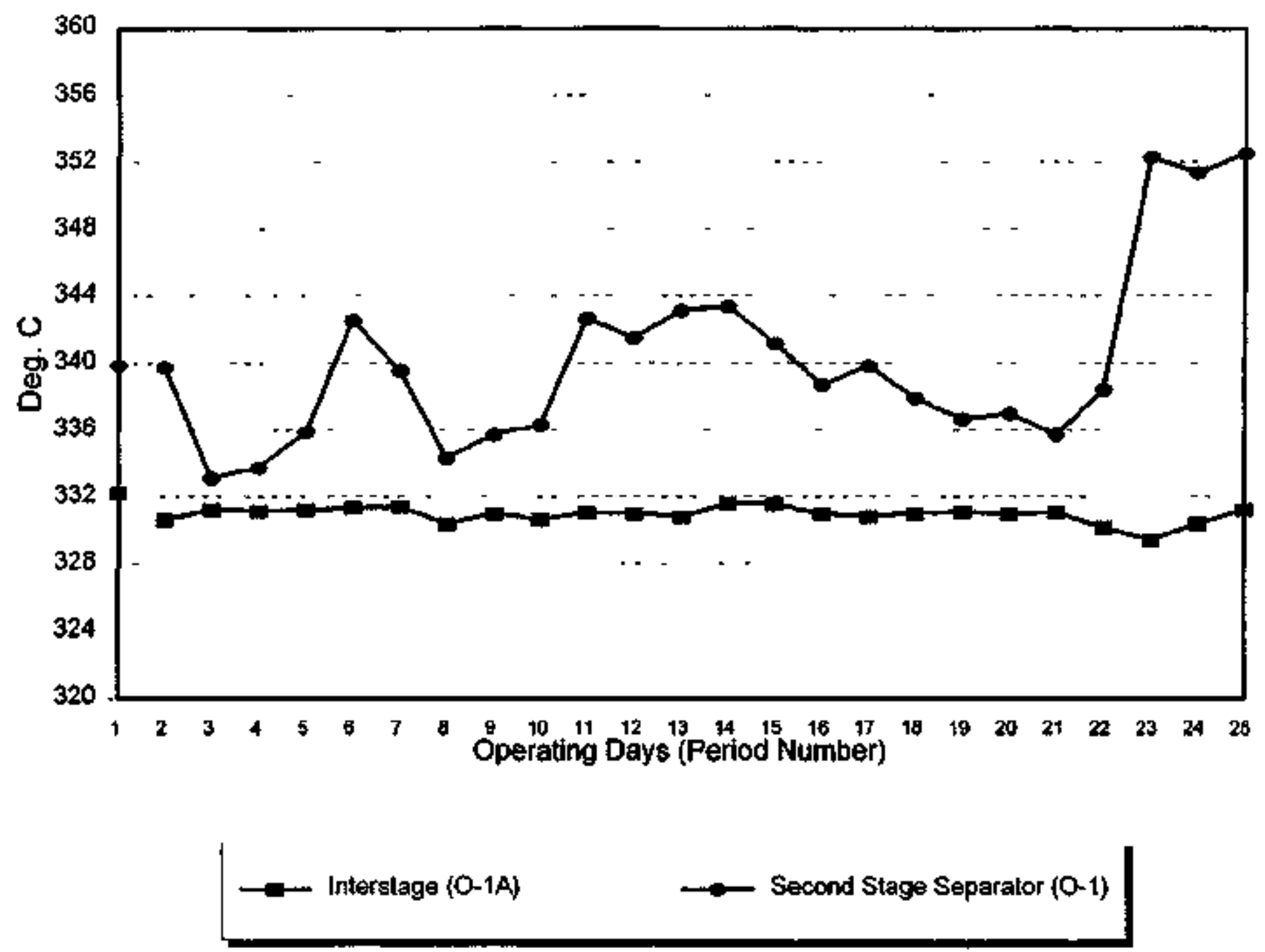


Figure 9

\section{Space Velocity}
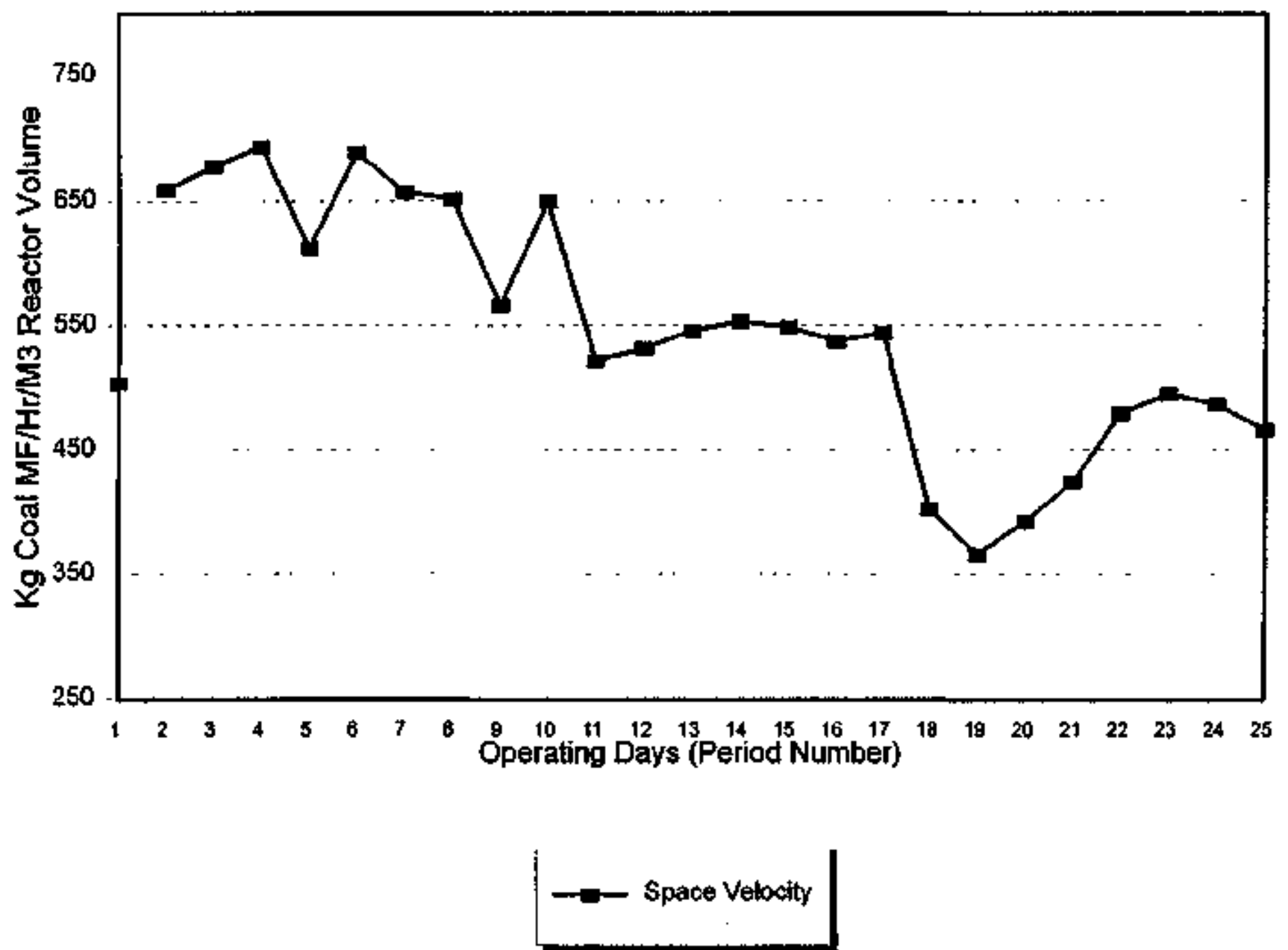
Figure 10

\section{Daily Material Balance}

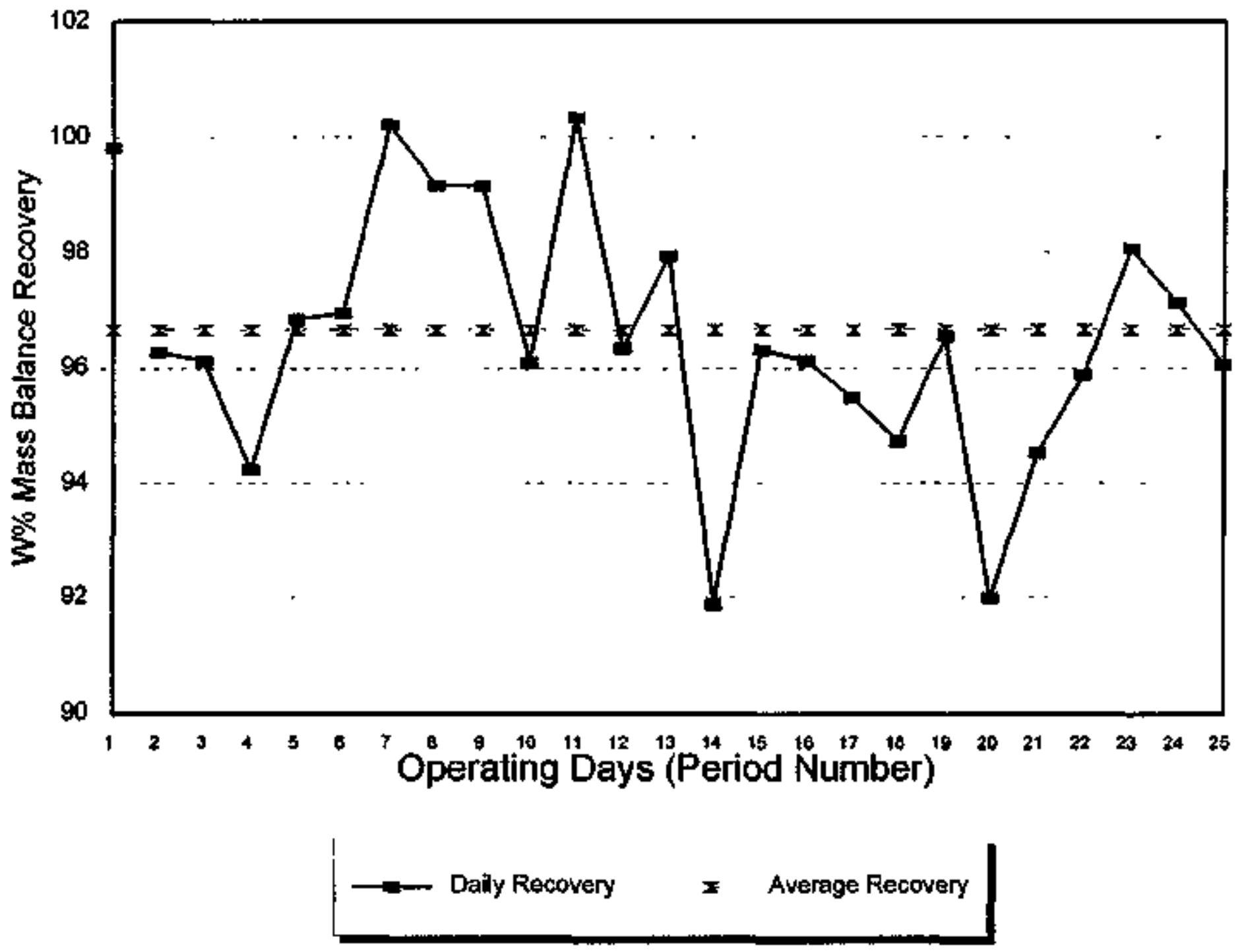


Figure 11

\section{C4-524 C Distillate Yield \& $524 \mathrm{C}+$ Yield}

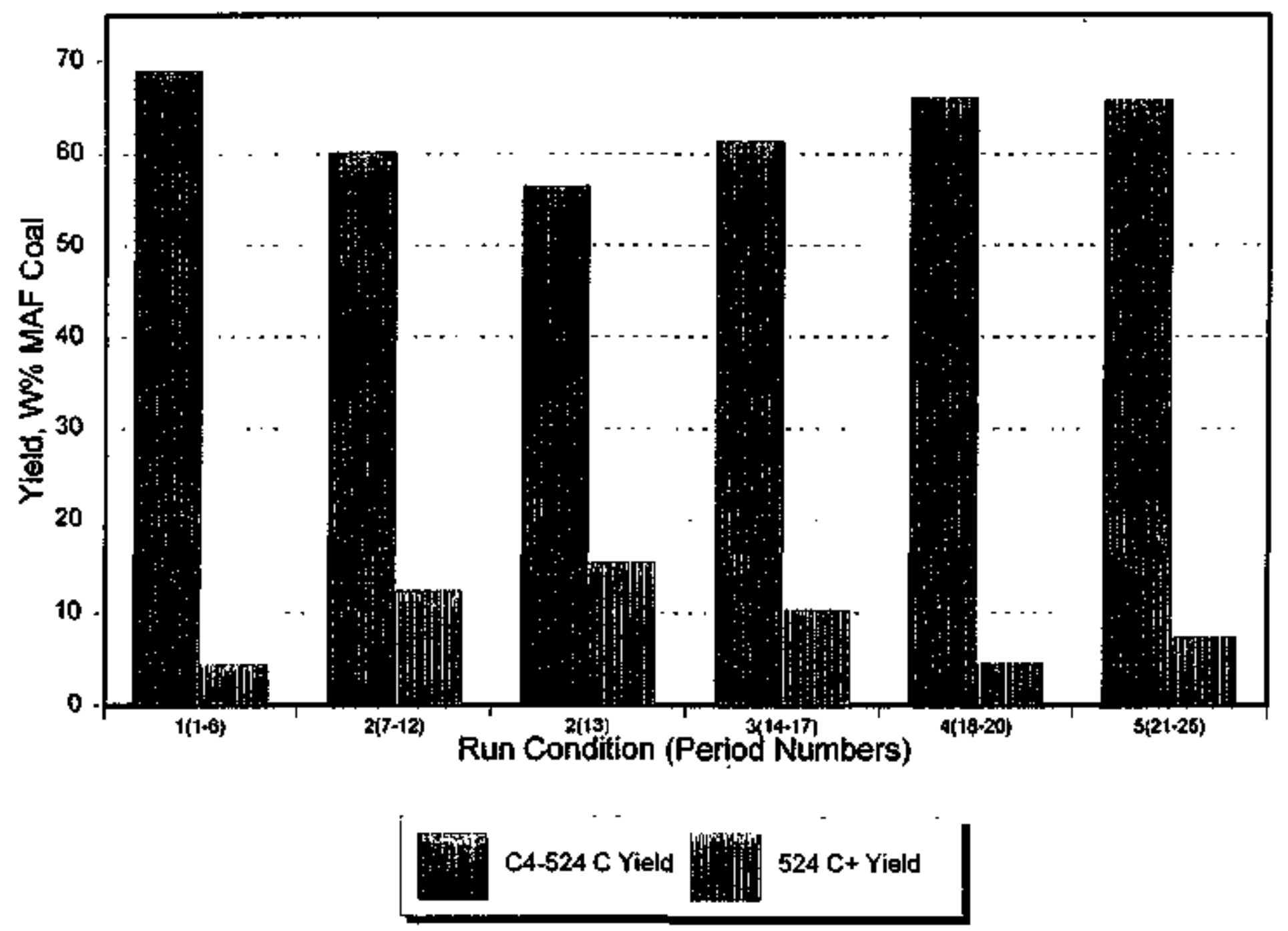


Figure 12

\section{Distillate Fraction Yields}

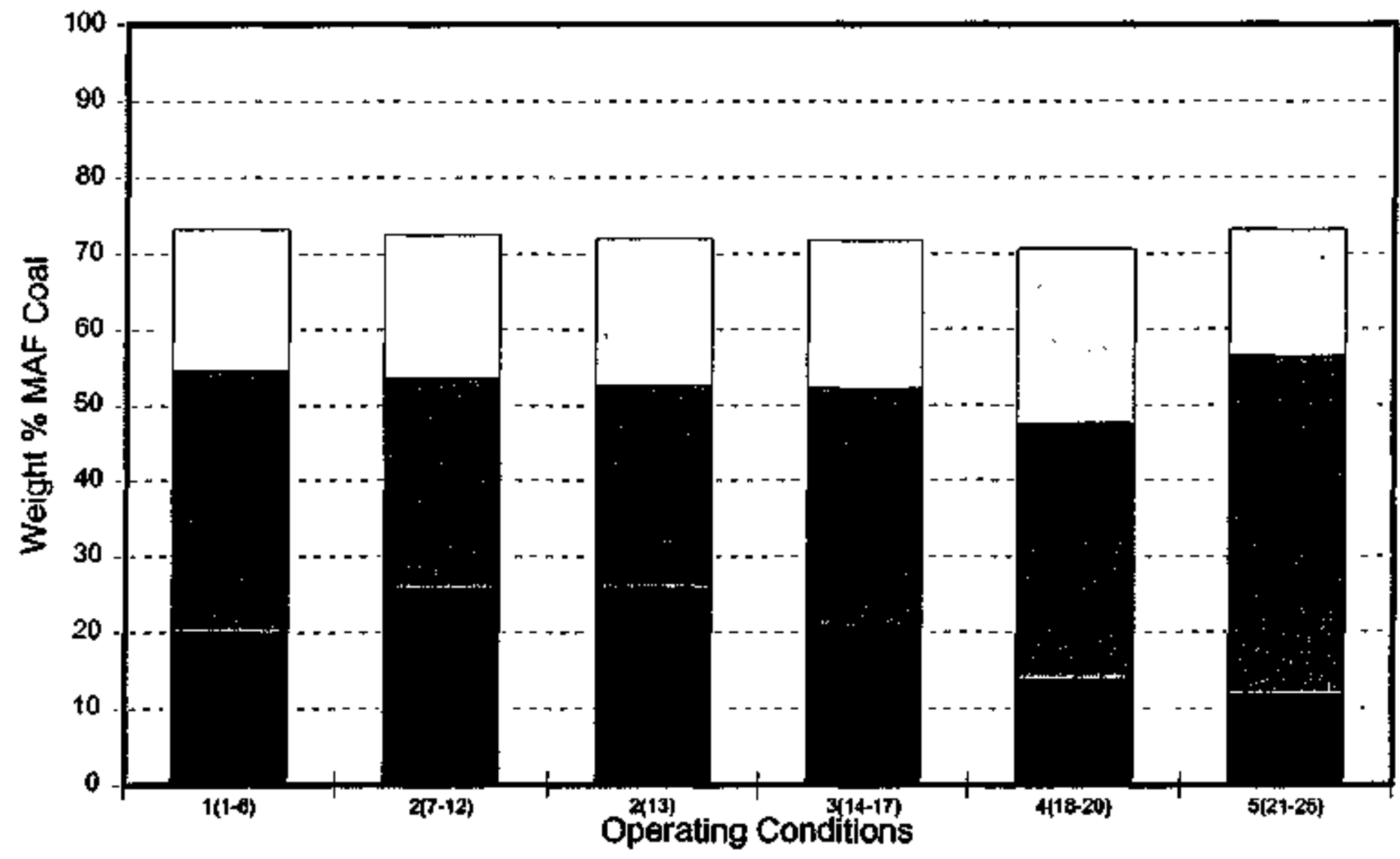


Figure 13

\section{Distillate Fraction Selectivity}

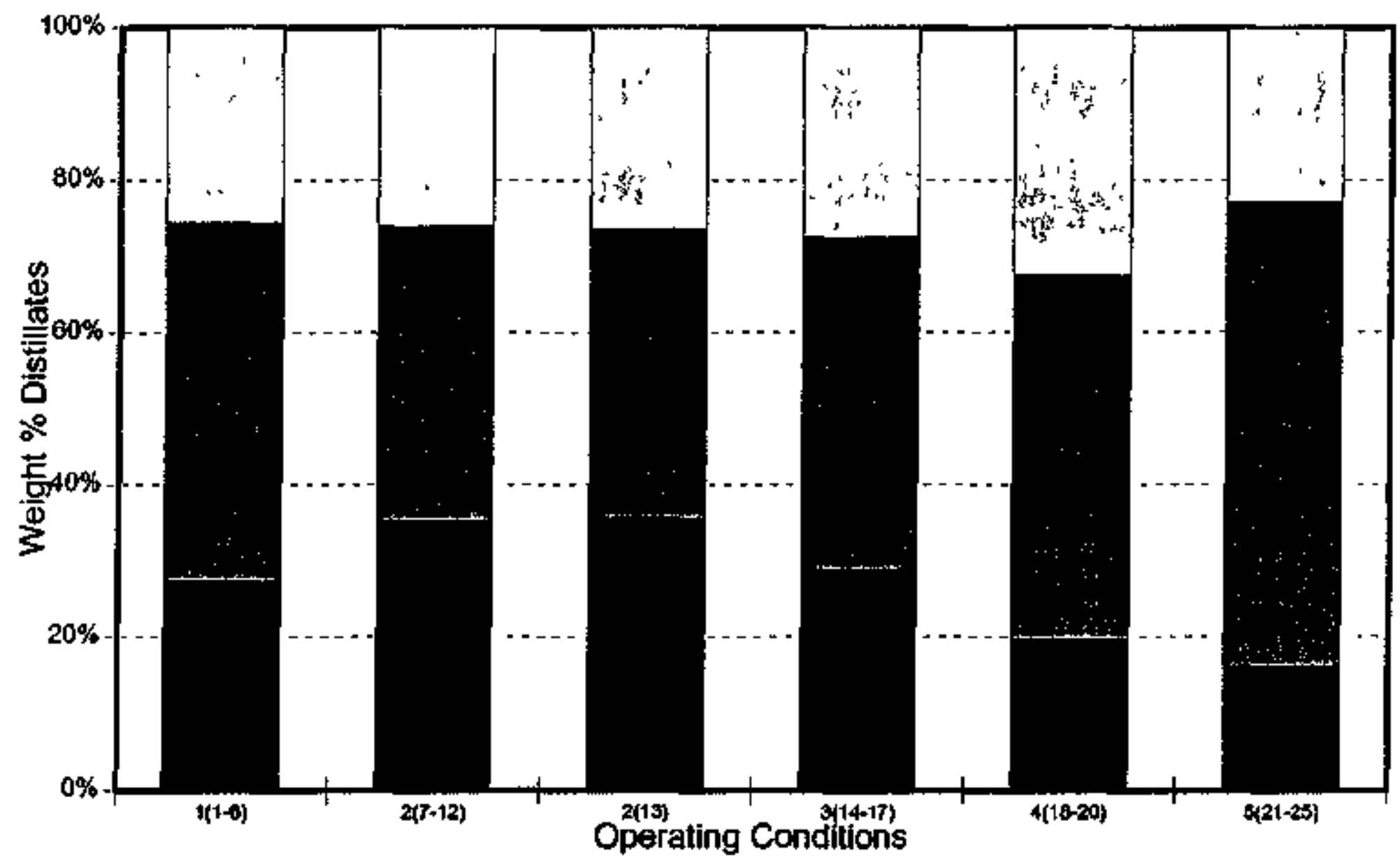


Figure 14

\section{Hydrogen Consumption \& Light C1-C3 Gas Yield}

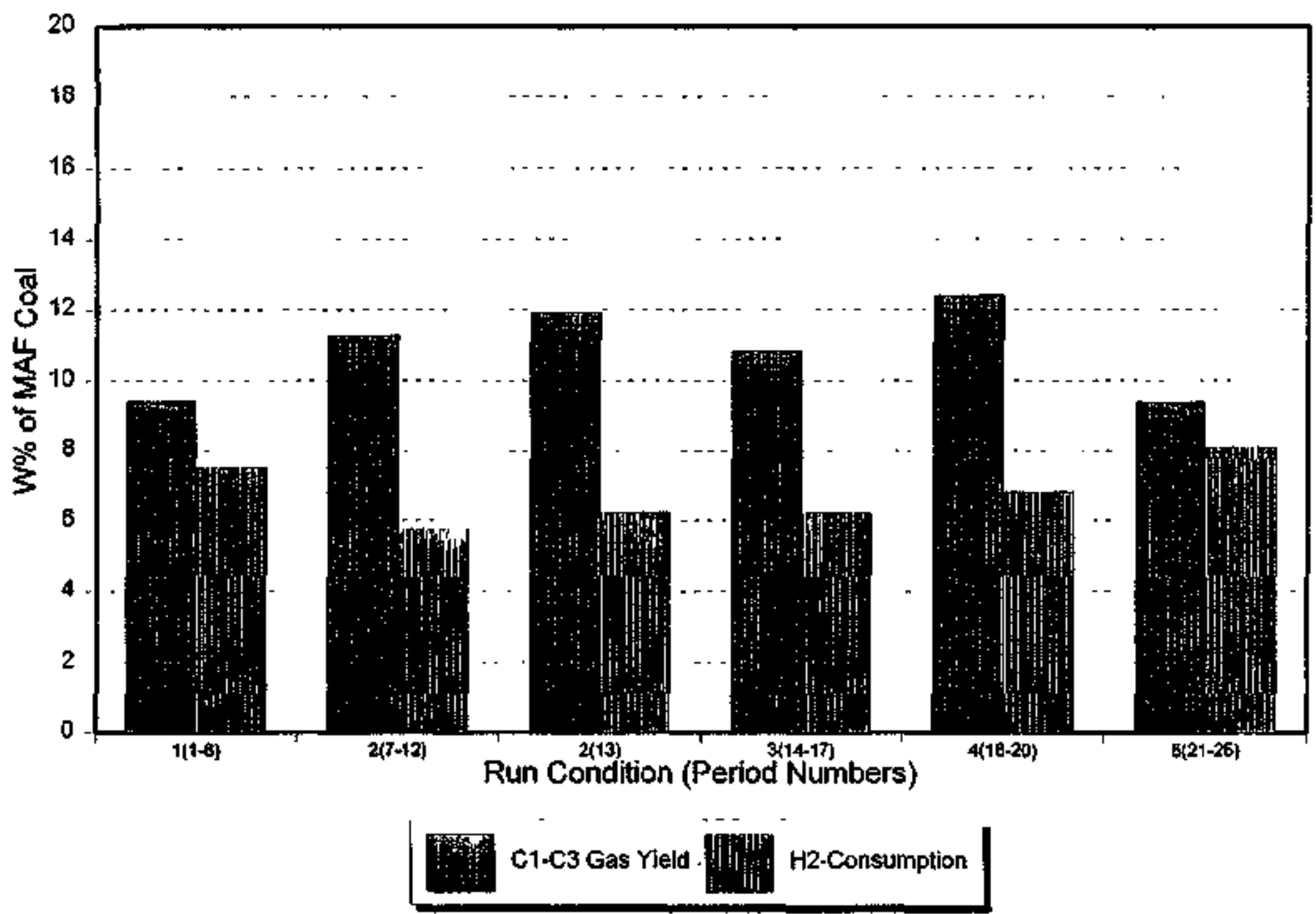


Figure 15

\section{Hydrogen Efficiency}

\&. C1-C3 Gas Selectivity

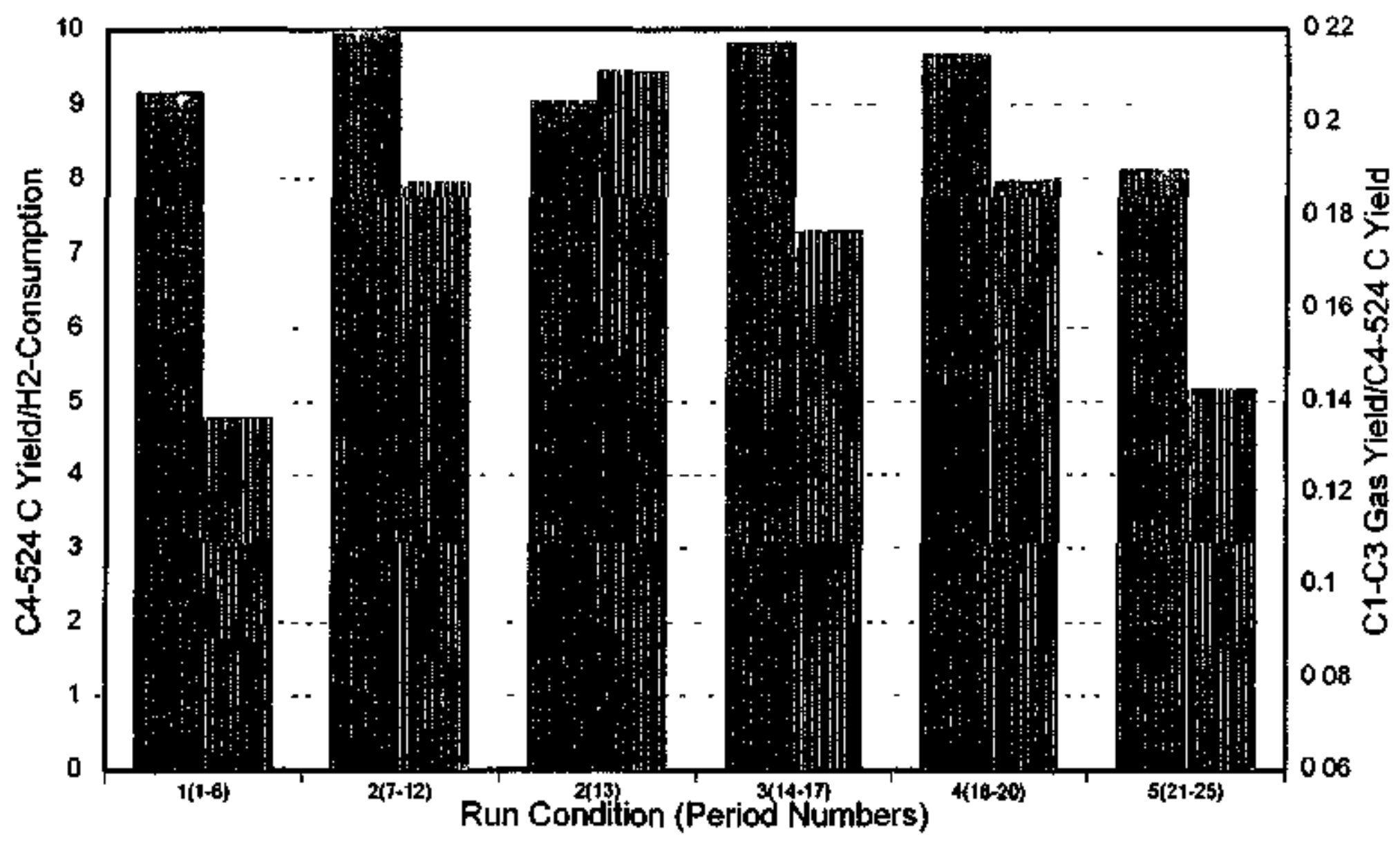


Figure 16

\section{Quality of Second Stage SOH Oil}

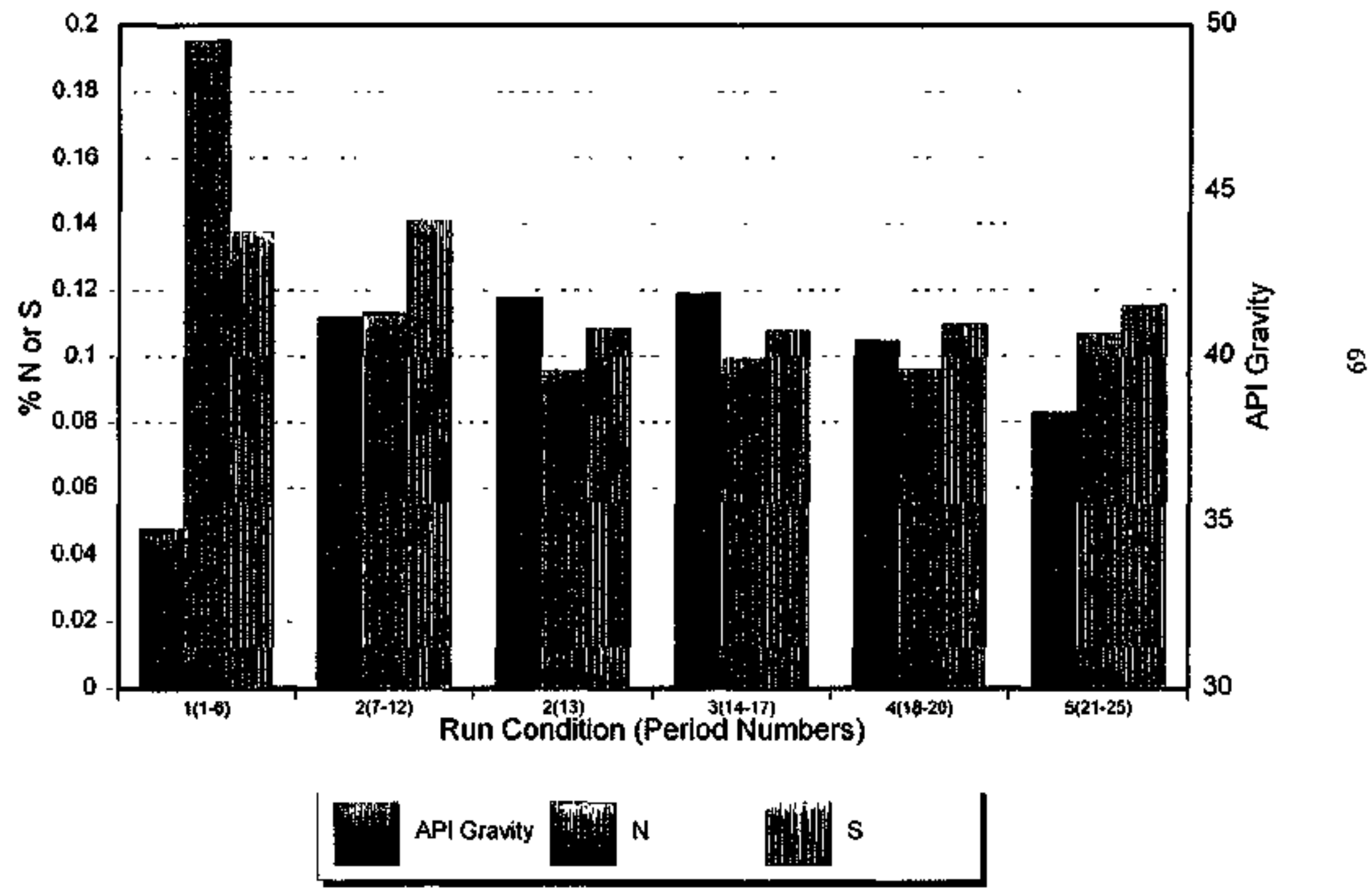




\section{Appondix A}

\begin{tabular}{|c|c|c|c|c|c|c|}
\hline 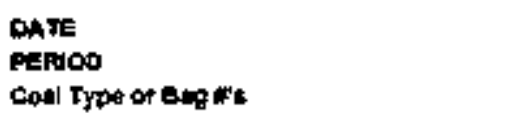 & $\begin{array}{l}\text { 19-Apr-9s } \\
1 \\
\text { Raw Coal }\end{array}$ & $\begin{array}{l}20-A p r-96 \\
2 \\
\text { Raw Cogl }\end{array}$ & $\begin{array}{c}21 \text { Apr-s6 } \\
3 \\
\operatorname{Rrw} \operatorname{Cog} 1\end{array}$ & $\begin{array}{l}22 \times A p r-96 \\
\text { Row Coar }\end{array}$ & $\begin{array}{l}23 \text { Apr-as } \\
5 \\
\text { Raw Coal }\end{array}$ & $\begin{array}{c}24-A p r-86 \\
6 \\
\text { Ran Coat }\end{array}$ \\
\hline \multicolumn{7}{|l|}{ FEeOS gms } \\
\hline $\begin{array}{l}\text { COAL: 8latk Thumar } \\
\text { Was otd Agg 에 } \\
\text { Woan Oㅇ }\end{array}$ & 25845 & 33810 & 34770 & 35502 & $\$ 1366$ & 35303 \\
\hline \multirow{2}{*}{\multicolumn{7}{|c|}{$\begin{array}{l}\text { FF4 } \\
\text { FF5 }\end{array}$}} \\
\hline & & & & & & \\
\hline Motyvan - A & 10.12 & 10.63 & 10.89 & 11.16 & 0.82 & 11.13 \\
\hline Fr-basod Cetalyat & 2947 & 3097 & 3172 & 3249 & 2890 & $\mathbf{3 2 4 2}$ \\
\hline H2s & 945 & $\operatorname{sen}$ & at & 903 & ges & 1012 \\
\hline Thes & 2489 & 2667 & $25 \$ 1$ & 255s & 2659 & 2723 \\
\hline Mks-up on & 1747 & 5399 & 6689 & & & \\
\hline $\begin{array}{l}\text { VSB } \\
\text { VSOH2 }\end{array}$ & & & & 2788 & 10253 & 9215 \\
\hline \multicolumn{7}{|l|}{$\begin{array}{l}\text { VSOH2 } \\
\text { VSOH1 }\end{array}$} \\
\hline \multicolumn{7}{|l|}{ 976F.VSOH } \\
\hline \multicolumn{7}{|l|}{$\begin{array}{l}\text { ASOH } \\
\text { ANTERSTAGEE }\end{array}$} \\
\hline \multirow{2}{*}{\multicolumn{7}{|c|}{$\begin{array}{l}\text { SOH-OHL } \\
\text { SOH-H2O }\end{array}$}} \\
\hline & & & & & & \\
\hline $\begin{array}{l}\mathrm{FrL} \\
\mathrm{PFC}\end{array}$ & 53280 & $\begin{array}{c}41793 \\
2283\end{array}$ & $\begin{array}{l}42107 \\
1904\end{array}$ & $\begin{array}{l}46626 \\
2756\end{array}$ & $\begin{array}{l}30107 \\
6726\end{array}$ & 35020 \\
\hline Whater & 9269 & 8508 & 8462 & 6567 & 8 & 8916 \\
\hline Hedrogenen foed & 7072 & 7067 & 7073 & 7068 & 7055 & 7052 \\
\hline TOTAL FEED & 103594 & 105547 & 107736 & 130084 & 100753 & 111142 \\
\hline \multicolumn{7}{|l|}{ Froducts, gms } \\
\hline Hydropen In Protuct Otoel & 6076 & 4238 & 4440 & 4067 & 4506 & 4653 \\
\hline Product Gen (hydrogen \& nitragen fros) & 8390 & 8206 & 6030 & 6472 & 7901 & 62BS \\
\hline \multicolumn{7}{|l|}{$\begin{array}{l}\text { VSS } \\
\text { VSOH? }\end{array}$} \\
\hline \multicolumn{7}{|l|}{ VSOH' } \\
\hline \multicolumn{7}{|l|}{ 975F.vsok } \\
\hline $\begin{array}{l}\text { ASOH } \\
\text { INTERSTAGE }\end{array}$ & & 4143 & 13929 & 6077 & 1428 & \\
\hline $\mathrm{SOH} \cdot \mathrm{OH}$ & 10444 & $\$ 5769$ & $\$ 268$ & 8823 & 9035 & 14794 \\
\hline $\mathrm{SOH} \cdot \mathrm{H} 2 \mathrm{O}$ & 14265 & 29711 & 20138 & 28114 & 20873 & $\$ 8701$ \\
\hline PFL & 61620 & 4801 & 44496 & 45952 & 43402 & 50113 \\
\hline $\mathrm{PFC}$ & 2002 & 4760 & 4357 & 5439 & 10349 & $\$ 3215$ \\
\hline TOTAL PROOUCTS & $\$ 03406$ & $\$ 01629$ & 103664 & 103744 & $97 \$ 84$ & 107761 \\
\hline RECOVERY, W\% & 99.82 & 56.29 & 50.13 & 94.24 & 98.60 & 90.96 \\
\hline \multicolumn{7}{|l|}{ FEED BTREAM RATO' ( to MF COSAl) } \\
\hline 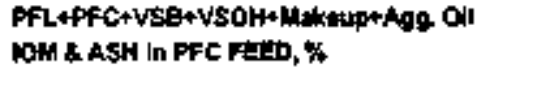 & 2.32 & $\begin{array}{l}1.60 \\
6.08\end{array}$ & $\begin{array}{l}1.60 \\
5.20\end{array}$ & $\begin{array}{l}1.61 \\
6.50\end{array}$ & $\begin{array}{r}1.63 \\
19.07\end{array}$ & $\begin{array}{l}1,63 \\
22.71\end{array}$ \\
\hline Meterred H2 Cons. whe muf cood & 4.46 & 9.77 & 8.85 & 7.22 & 9.07 & 7.92 \\
\hline \multicolumn{7}{|l|}{ 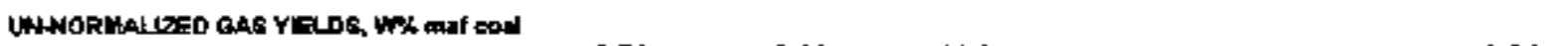 } \\
\hline$K-1 \leq K+1: C 1 C \$$ Gan Yietd & 15.72 & 15.63 & 11.04 & 10.97 & 14.74 & 9.94 \\
\hline$k+1$ \& K-2: C4Ct Gas Yind & 10.78 & 5.70 & $\$ .44$ & 5.05 & 6.40 & 4.68 \\
\hline$k-1 \& k-1$ : cox Gat Yiete & 11.15 & 7.02 & 5.94 & 5.21 & 8.00 & 5,84 \\
\hline K.1 : C1.C3 Gas Yield & 7.19 & 518 & 4.58 & 4.63 & 5.72 & 484 \\
\hline K-1 : CAC7 Gal Yiedd & 4.65 & 192 & 1.70 & 3.19 & 3.39 & 2.84 \\
\hline$K-1 ; \cos \cos Y_{\text {Keld }}$ & 10.24 & 5.95 & 5.11 & 4.72 & 7.44 & 5.32 \\
\hline $\begin{array}{l}\text { Dry Cosi Food, gms } \\
\text { Cakculated Cosl Hodswre Conkent WX }\end{array}$ & $\begin{array}{l}23762 \\
8.06\end{array}$ & $\begin{array}{l}30845 \\
8.77\end{array}$ & $\begin{array}{c}31697 \\
8.84\end{array}$ & $\begin{array}{c}32458 \\
8.70\end{array}$ & $\begin{array}{c}28884 \\
7.97\end{array}$ & $\begin{array}{l}32405 \\
8.21\end{array}$ \\
\hline \multirow[t]{2}{*}{ Coal Convertion, 803 ine } & & 93.38 & 93.80 & 95.14 & 05.44 & 94.98 \\
\hline & \multicolumn{6}{|c|}{70} \\
\hline
\end{tabular}


Appendix B

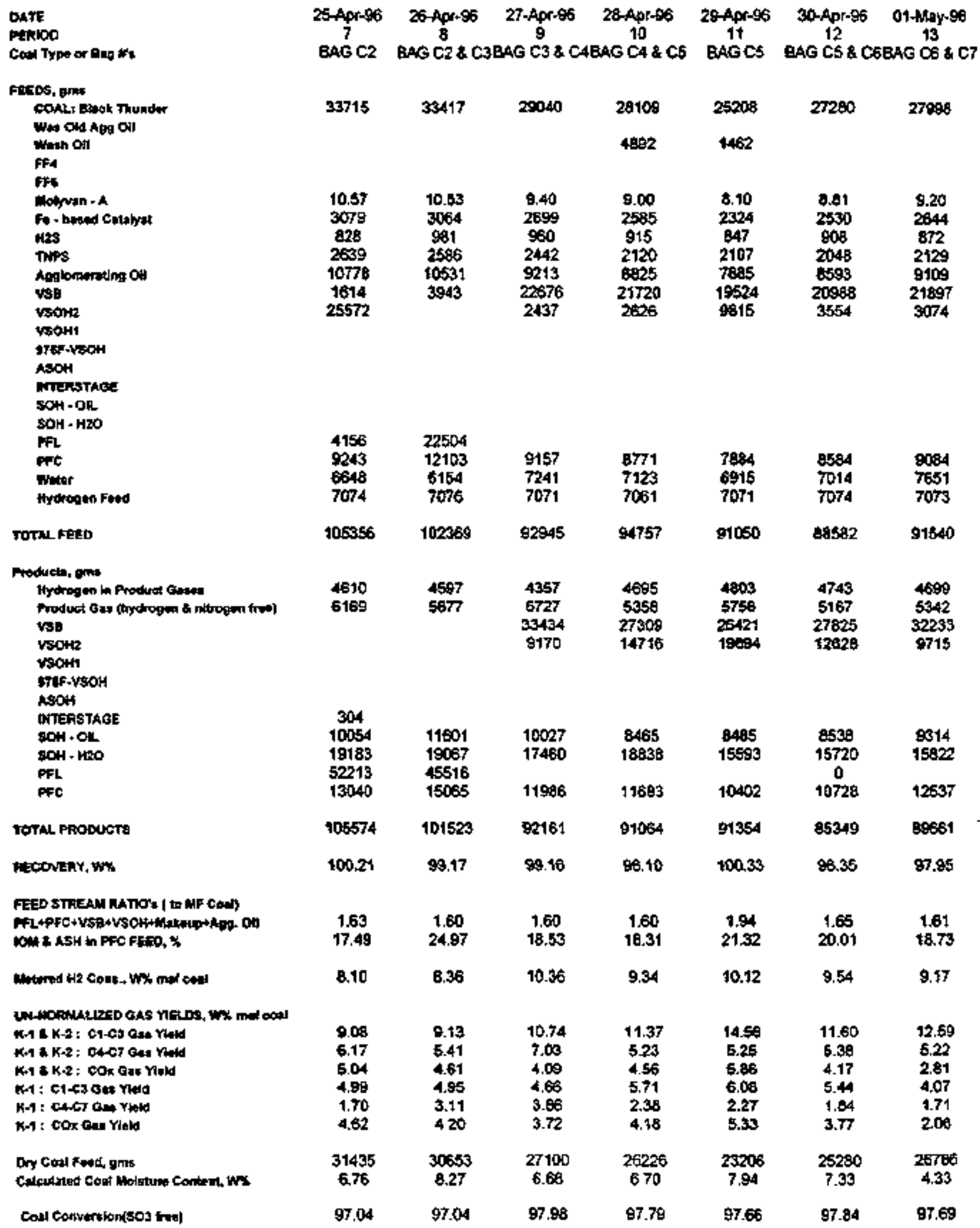




\section{Appendix $C$}

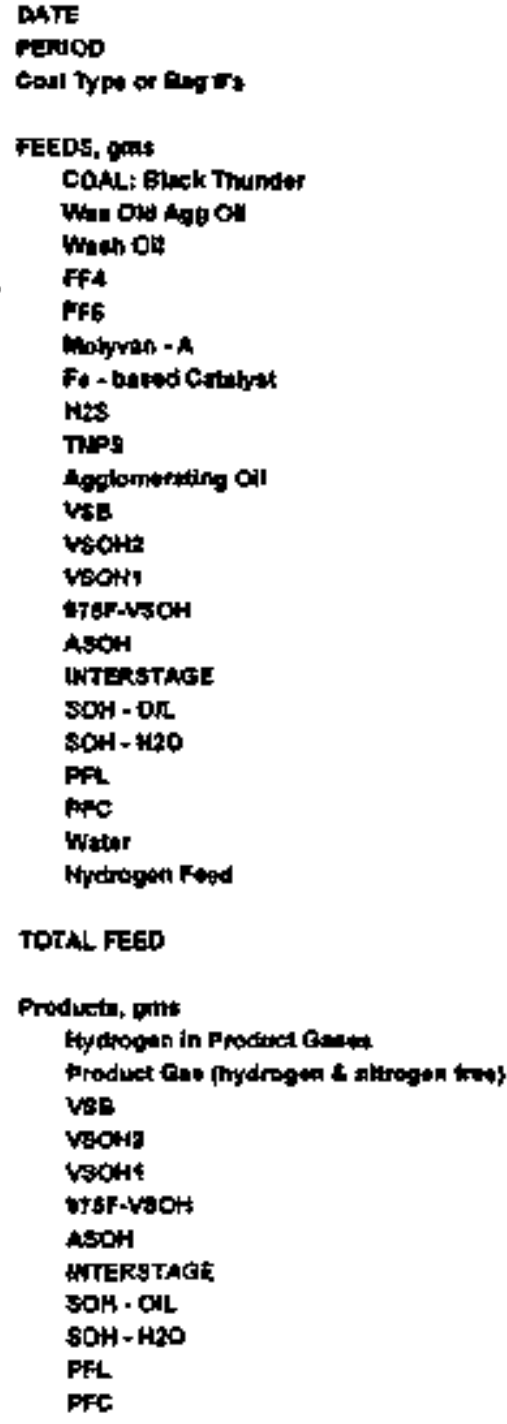

Cosl Comwenon, sos free

\begin{tabular}{|c|c|c|c|}
\hline $\operatorname{May}_{14}=6$ & $\begin{array}{c}03-\text { Marses } \\
15 \\
\text { BAo C7 scs }\end{array}$ & $\begin{array}{c}\text { O4hays } 95 \\
16 \\
\text { BAG CB }\end{array}$ & $\begin{array}{c}05-4 y_{4} 98 \\
17 \\
\text { BAs CA a C9 }\end{array}$ \\
\hline
\end{tabular}

28363

28138

27569

27897

$\begin{array}{cccc}6.56 & 6.61 & 6.40 & 644 \\ 1913 & 1897 & 1867 & 1877 \\ 965 & 943 & 689 & 858 \\ 2118 & 2198 & 2111 & 2195 \\ 9238 & 9145 & 8001 & 9036 \\ 22178 & 21994 & 22039 & 20361 \\ 4708 & 2514 & 2532 & 2597\end{array}$

\begin{tabular}{|c|c|c|c|}
\hline $\begin{array}{l}9200 \\
8037 \\
7069\end{array}$ & $\begin{array}{l}9124 \\
7995 \\
7055\end{array}$ & $\begin{array}{l}8981 \\
8037 \\
7035\end{array}$ & $\begin{array}{l}9030 \\
6672 \\
7075\end{array}$ \\
\hline 83805 & 91009 & $\$ 0307$ & 89004 \\
\hline $\begin{array}{c}4656 \\
5951 \\
29516 \\
7491 \\
2436\end{array}$ & $\begin{array}{l}4607 \\
6634 \\
31120 \\
7600 \\
2465\end{array}$ & $\begin{array}{c}4723 \\
4821 \\
27739 \\
11242 \\
1877\end{array}$ & $\begin{array}{c}4634 \\
5240 \\
28392 \\
10524 \\
1685\end{array}$ \\
\hline $\begin{array}{c}287 \\
8204 \\
16186\end{array}$ & $\begin{array}{c}8174 \\
14643\end{array}$ & $\begin{array}{c}6789 \\
16097\end{array}$ & $\begin{array}{l}9449 \\
13867\end{array}$ \\
\hline 11426 & 12717 & $\$ 1531$ & 11775 \\
\hline $86+95$ & A7680 & 86B十9 & 85568 \\
\hline 91.89 & 96.32 & 96.14 & 95.49 \\
\hline $\begin{array}{c}1.67 \\
19.31\end{array}$ & $\begin{array}{c}1.60 \\
19.37\end{array}$ & $\begin{array}{c}7.62 \\
17.05\end{array}$ & $\begin{array}{c}163 \\
21.73\end{array}$ \\
\hline 9.04 & 9.43 & 923 & 9.5 \\
\hline $\begin{array}{l}13.18 \\
4.65 \\
4.63 \\
5.55 \\
7.87 \\
4.08\end{array}$ & $\begin{array}{l}12.02 \\
6.97 \\
4.59 \\
6.09 \\
5.51 \\
4.52\end{array}$ & $\begin{array}{c}11.73 \\
5.52 \\
1.67 \\
4.18 \\
1.86 \\
1.26\end{array}$ & $\begin{array}{l}11.22 \\
4.95 \\
4.34 \\
5.96 \\
2.44 \\
4.08\end{array}$ \\
\hline $\begin{array}{c}27123 \\
4.44\end{array}$ & $\begin{array}{c}26813 \\
471\end{array}$ & $\begin{array}{c}26328 \\
450\end{array}$ & $\begin{array}{c}28365 \\
549\end{array}$ \\
\hline 97.86 & 98.06 & 98.71 & 97.58 \\
\hline
\end{tabular}


Appendix D

DATE

PenioO

cosd type or therers

Fitos 대

Colt: Pleck Thunder

we ONd Aor on

When OAl

rit

Fit

rompen - 1

Fo-kneat Condrat

Has

tivips

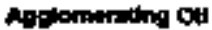

vis

volt2

vort1

orstyot

isotit

HTAF'ACE

s01 + 04

san - H2O

PrL

PFC

whor

Hroteren tiat

TOTL Fבש

Productit. orne

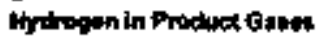

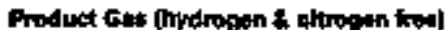

บ5.

vorat

vorit

\$7FF-4isor

1404

IWTERSTAOE

80* - or

엇 - 120

rey.

PFC

TOTAL Fropucts

RECQYERY, WH

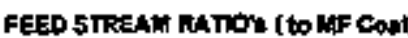

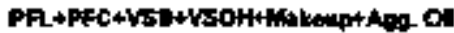

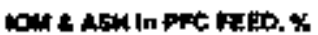

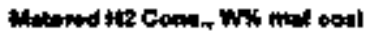

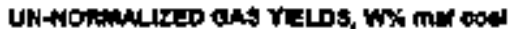

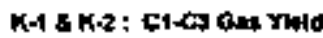

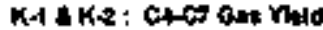

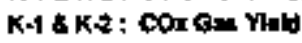

K-1 : C1-C1 Gat Yald

$K-1$; C4C7 Git YNod

K-1 : cox rat role

Orf Carl Fud, ems

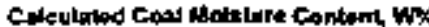

call Oonitonlon, cos thes

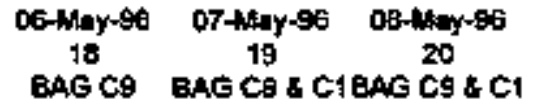

$20524 \quad 18807 \quad 20122$

$\begin{array}{ccc}4,92 & 4.47 & 4.74 \\ 1457 & 1294 & 1367 \\ 964 & 938 & 953 \\ 1657 & 1508 & 1529 \\ 6930 & 6244 & 6594 \\ 17178 & 15497 & 16410 \\ 2345 & 2691 & 3328\end{array}$

$\begin{array}{lll}6930 & 6240 & 6610 \\ 8742 & 9234 & 6999 \\ 7073 & 7068 & 7070 \\ 73902 & 69532 & 72993\end{array}$

$4981 \quad 5023 \quad 4+974$

$\begin{array}{lll}4138 & 4144\end{array} \mathbf{4 2 9}$

$47809 \quad 17721 \quad 17475$

$10236 \quad 7623 \quad 6344$

$\begin{array}{lll}1751 & \$ 1070\end{array}$

$\begin{array}{lll}322 & 7600 & 7618\end{array}$

$14677 \quad 13133 \quad 12721$

$8497 \quad 6052 \quad 8979$

$\begin{array}{lll}70011 & 67134 & 67159\end{array}$

$94.74 \quad 95.55 \quad 92.01$

$1.65 \quad 1.63 \quad 1.64$

$21,23 \quad 21.61 \quad 1976$

$10.69 \quad 11.26 \quad 11.39$

$10.64 \quad 13.37 \quad 12.21$

$711 \quad 527 \quad$ B. 09

$3.38 \quad 421 \quad 4.01$

$5.75668 \quad 616$

$2.57 \quad 2.54 \quad 2.51$

$328 \quad 403 \quad 3.84$

$20189 \quad 16766 \quad 20079$

$\begin{array}{lll}211 & 0.22 & 0.22\end{array}$

$\begin{array}{lll}99 & 97.51 & 97.49\end{array}$ 
Appendix $E$

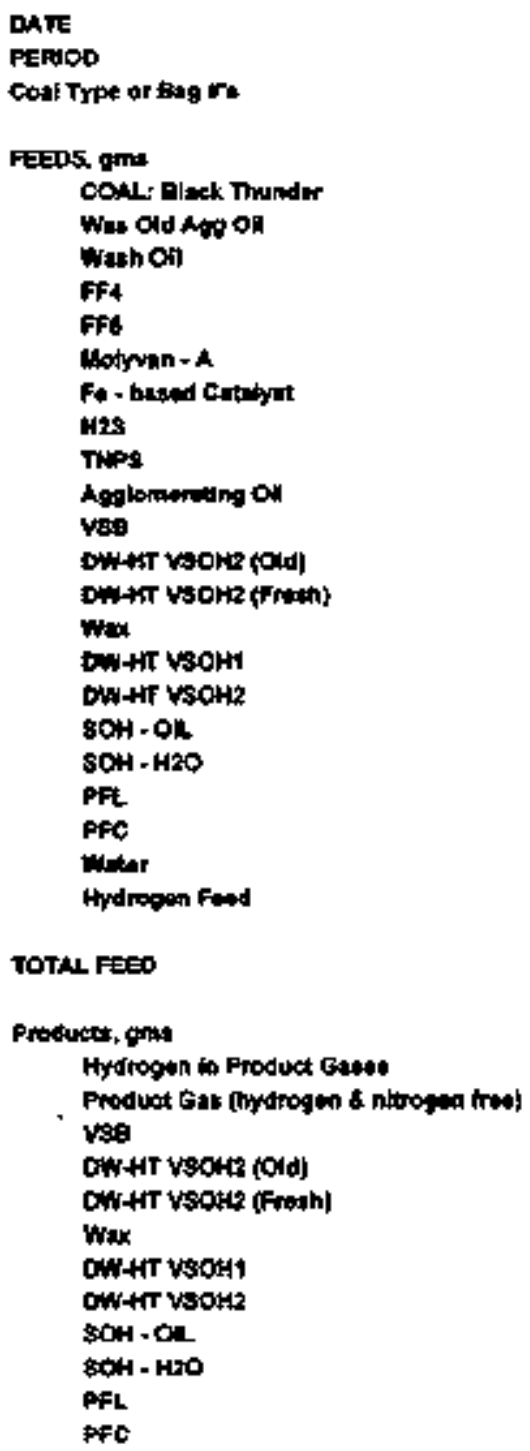

TOTHAL PRODUCTS

NECONERY, WH

FEEO STREHARTO': 1 to wF COAll

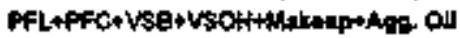
COA A ASH in PFC FETD, $x$

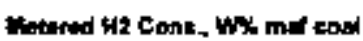

\begin{tabular}{|c|c|c|c|}
\hline $\begin{array}{c}09 \text { Mry-pes } \\
21 \\
\text { Row Cosd }\end{array}$ & $\begin{array}{c}10-\mathrm{N}=\mathrm{r}-96 \\
22 \\
\mathrm{R}\end{array}$ & $\begin{array}{c}\text { S1-May-os } \\
23 \\
\text { Raw Cos }\end{array}$ & $\begin{array}{c}12+\text { way-s6 } \\
24 \\
\text { Row Colal }\end{array}$ \\
\hline
\end{tabular}

$\begin{array}{lllll}21764 & 24596 & 25398 & 24964 & 23899\end{array}$

$\begin{array}{ccccc}5.17 & 5.64 & 5.71 & 0.58 & 5.38 \\ 1501 & 1637 & 1655 & 1618 & 1561 \\ 986 & 691 & 940 & 931 & 889 \\ 1687 & 1857 & 1989 & 1877 & 1893 \\ & & & & \\ 10418 & 10337 & 7476 & 7493 & 6398 \\ 47237 & 19654 & 7094 & 16216 & 7130 \\ & & 14348 & 3243 & 12702\end{array}$

\begin{tabular}{|c|c|c|c|c|}
\hline $\begin{array}{l}6875 \\
8335 \\
7071\end{array}$ & $\begin{array}{l}7783 \\
8318 \\
7073\end{array}$ & $\begin{array}{l}7871 \\
8107 \\
7061\end{array}$ & $\begin{array}{l}7095 \\
7456 \\
7067\end{array}$ & $\begin{array}{l}7420 \\
7649 \\
7069\end{array}$ \\
\hline 75879 & 82162 & 64915 & 78565 & 78622 \\
\hline $\begin{array}{l}5200 \\
4007 \\
7456\end{array}$ & $\begin{array}{l}5168 \\
5203 \\
6828\end{array}$ & $\begin{array}{l}5193 \\
5448 \\
9365\end{array}$ & $\begin{array}{l}5317 \\
5527 \\
8426\end{array}$ & $\begin{array}{l}5260 \\
4285 \\
7259\end{array}$ \\
\hline $\begin{array}{l}1339 \\
7170 \\
45408 \\
8048 \\
13837\end{array}$ & $\begin{array}{c}1274 \\
1770 \\
16449 \\
10282 \\
14750\end{array}$ & $\begin{array}{c}107 t \\
5436 \\
17300 \\
8797 \\
15234\end{array}$ & $\begin{array}{c}1518 \\
6918 \\
13054 \\
8970 \\
14712\end{array}$ & $\begin{array}{c}906 \\
6519 \\
14919 \\
9017 \\
13051\end{array}$ \\
\hline 9250 & 12683 & 12391 & 11869 & 12307 \\
\hline 71731 & 76787 & 80335 & 70312 & 13602 \\
\hline 94,53 & 95.89 & 96.07 & 97.13 & 96.06 \\
\hline $\begin{array}{c}1.64 \\
20.43\end{array}$ & $\begin{array}{c}1.64 \\
2.58\end{array}$ & $\begin{array}{c}1.56 \\
20.05\end{array}$ & $\begin{array}{c}1.50 \\
15.58\end{array}$ & $\begin{array}{c}1,51 \\
17.89\end{array}$ \\
\hline 9.46 & 8.62 & 8.42 & 8.06 & 8.62 \\
\hline $\begin{array}{c}10.49 \\
3.99 \\
5.70 \\
7.24 \\
2.38 \\
5.64\end{array}$ & $\begin{array}{l}12.85 \\
4.97 \\
6.27 \\
8.86 \\
2.20 \\
5.89\end{array}$ & $\begin{array}{l}12.55 \\
5.52 \\
6.47 \\
0.53 \\
2.23 \\
6.14\end{array}$ & $\begin{array}{c}13.61 \\
5.13 \\
6.83 \\
5.88 \\
2.07 \\
6.27\end{array}$ & $\begin{array}{l}9.67 \\
409 \\
0.46 \\
0.05 \\
2.45 \\
6.31\end{array}$ \\
\hline $\begin{array}{c}21061 \\
3.23\end{array}$ & $\begin{array}{c}23014 \\
6.43\end{array}$ & $\begin{array}{c}23643 \\
6.91\end{array}$ & $\begin{array}{c}23114 \\
7.41\end{array}$ & $\begin{array}{c}22382 \\
643\end{array}$ \\
\hline 98.09 & 95.48 & 98.26 & 96.64 & 94.72 \\
\hline
\end{tabular}




\section{Appendix F: SUMMARY OF OPERATIONS}

\section{Unit Modification and Configuration}

For Run ALC-1, Unit-227 was set up to process sub-bituminous coal using two $2000 \mathrm{cc}$ reactor stages with interstage product separation. Both stages contained no supported catalyst, using shurry catalysts mixed with the feed. Prior to the run, the systern was modified to the following configuration:

- Two equai volume back-mixed reactors with internal re-circulation.

- Two liquefaction scages operated as slurry reactors at different temperatures. Dispersed Fe and Molyvan-A casalysts were used in all conditions.

- Preheater (essentially a coil preheater, 5 min residence rime)

- Interstage separation and sampling system.

- Pressure filtration of CAS bonoms (0-6 bouoms).

- Vacrum stili to fractionare PFL into VSOH and VSB excepr for Condition 1.

- Toluene extraction of PFC.

- In-line hydrotreater temperature was set at $379^{\circ} \mathrm{C}$.

- The cut point of the continuous aumospheric still was set at $329^{\circ} \mathrm{C}$.

- Vaculum still temperature was set at differem values for different conditions \{412$\left.524^{\circ} \mathrm{C}\right)$

- In condition 5. VSOH was dewaxed and hydrotreated prior to recycle.

- Hydroureating of dewaxed VSOH was conducted off-line at $360^{\circ} \mathrm{C}$ and $15 \mathrm{MPa}$ of $\mathrm{H}_{2}$

\section{Startup}

Startup consisted of establishing the proper flows of oil and gases, presulfiding the catalyst in the hydrotreater, setting vessel temperatures, testing the first stage sample system, and increasing the reactor temperatures to $413^{\circ} \mathrm{C}$. Filtered L-814, heavy gas oil, was used as a startup oil for this nun. The recycle material generated during the reactor heat-up period was used to slury the coal at the beginning of Period 1.

The startup was interrupted by a scale-like carbonaceous piug in the riser tube and bubble cap of K-1. 
Upon inspection, the reactor and top head assembly were found to be clean and clear. The startup was resumed.

Shortly after gas flows were reinitiated, the first stage sample collection cylinder electrical resistance heater controller failed, allowing the heater to run continuously. This set of events caused a plug to develop in the cylinder. The cylinder was taken off the unil for cleaning while the startup resumed.

Near the end of the startup procedure, there were level control problems in the atmospheric still (CAS), which caused heavy material to get into the top of the still and overhead vessel. These fluctuations were the result of cold control-valve and pressure-sensing lines due to blocked steam tracing lines.

\section{Condition 1 (Periods 1 through 6 )}

\section{Operating Conditions, Procedures, and Changes}

Period 1 started with the introduction of coal feed at 0500 hours April 19, 1996. (Each 24 hour period started and ender at 0400 hours.) The feed rate and reactor temperatures were gradualty increased, reaching fill coal rate of $1488 \mathrm{~g} / \mathrm{h}$ at 1600 houts and Condition 1 reactor temperatures of $443^{\circ} \mathrm{C}(\mathrm{K}-1)$ and $453^{\circ} \mathrm{C}(\mathrm{K}-2)$ at 2200 hours. By the middle of Period 3 the first toluene-extracted solid (ES, extracted filter cake) was available for recycle, and the full ES rate was attained in the middle of Period 5.

All of the V-100 bottoms were charged to the pressure filter. The PFL was recycled to the Unit, and the PFC was sent to the toluene-extractor. Some of the ES were recycled to the Unit.

By the end of Period 2, pressure fiturations required more than 3 hours. In Period 3, the hot separaior and CAS temperatures were decreased by $14^{\circ} \mathrm{C}$ to 329 and $315^{\circ} \mathrm{C}$, respectively, to matse the CAS bottons less viscous. Also in Period 3, some of the CAS battoms were added to the toluene extractor in addition to the entire PFC to filly utilize its $6000 \mathrm{~g}$ capacity. The IBP-399 ${ }^{\circ} \mathrm{C}$ cuts of the excess PFL and Extractor Oil (EO) were used to dilute the filter feed at the rate of about $15 \%$ of the CAS bottoms charge. Figure 2 presents the Downstream Product Flow Scheme at this time.

In Period 4, all the VSBs $\left(399^{\circ} \mathrm{C}+\right.$ ) cut from the PFL and from the EO were recycled to the charge to meet the goal of heavy liquid extinction. Also the ES were dried for 2 hours at $182^{\circ} \mathrm{C}$ with flowing nitrogen to remove any residual toluene. The $0-1$ temperature was increased by $6^{\circ} \mathrm{C}$, to $335^{\circ} \mathrm{C}$.

Because of flow disnuptions, causing extreme heavy oil and solids deposition throughout the column packing, the CAS was taken off line in Period S. Additional cuts were made in the vacuum still, with the $149-316^{\circ} \mathrm{C}$ fraction being pumped to the HTU (to replace the CAS overheads), the $316-399^{\circ} \mathrm{C}$ fraction used for pressure fitter diluent, and the $399^{\circ} \mathrm{C}+$ fraction used for Unit feed. The $\mathrm{BP}-149^{\circ} \mathrm{C}$ fraction of $E O$ was rerroved as residual toluene. 
Since the solids level in the unit had not reached a steady level by Period 5, Condition I was extended by 1 day to Period 6 . Also, to expedite solids recycle to the Unit, the extractor cycle time was decreased from 12 hours to 6 hours.

The last filtrations of Period 6 required mote than 4 hours and were discontimued to proceed with filtrations for the next condition. When the filtrations were discontimued, the unadulterated filtrate was collected before breaking the filter paper. The remaining slurry was then renun. Most filtrations went to completion in less than 1 hour after the 2-hour charges were divided between the two filters.

\section{Process and Equipment Operations}

During Condition 1 there were occasional feed pump stoppages. Most stoppages were very brief, but the backup feed pump had to be put on line three times. Feed outages exceeded 60 minutes twice during Period 5.

There were $0-1$ level control problems through Period 5. The level was erratic, sometimes causing decreased unit back pressure and excessive flow downstream to the 0.3 and CAS. The control valves were not dirty, but they did nor pass a steady flow umil a larger, " $G$ " trim was installed. Initial problems with the 0-1A level were alleviated when plugged steam tracing lines were cleared.

The CAS overflowed due to the flow surges from $0-1$ and $0-3$ and also when the discharge line plugged. Additionally, the CAS was off-Gine for 35 minutes after the relief vatve on the circulating pump stuck open, losing 1 gallon of slurry. With the reliability of the CAS hindered by these problems, it was taken off line in Period 5 for the remainder of the run.

Operations in the workup Period 6 were smooth except for a failed electric resistance heater in the hydrotreater. its temperature decreased by $110^{\circ} \mathrm{C}$ for 4 hours until it was repaired.

\section{Condition 2 (Periods 7-13)}

Operating Conditions, Procedures, and Changes

In Condition 2, the coal feed was changed from raw coal to coal previously cleaned by oil agglomeration at CONSOL, Inc. (HTI-6455). The $23 \%$ oil content of this coal necessitated a reduced oil recycle rate and an additional VSOH product. Accordingly, all PFL and EO was vaculum-distilled. For $\mathrm{EO}$, factions of $\mathrm{IBP}-149^{\circ} \mathrm{C}$ (toluene to storage), $149-316^{\circ} \mathrm{C}$ (6iter diluent), and $316^{\circ} \mathrm{C}+$ (Unit feed) were collected. PFL was fractionated into VSOH $\left(413^{\circ} \mathrm{C}\right.$-, storage and buffer oil) and VSB( $413^{\circ} \mathrm{C}+$, recycled). The PFC was recycled without toluene extraction. The original hourty feed blend was:

$\begin{array}{ll}\text { Coal (HTI-6455) } & 1953 \mathrm{~g} \\ \text { PFC } & 535 \mathrm{~g} \\ \text { VSB }\left(524^{\circ} \mathrm{C}+\text { from PFL }\right) & 671 \mathrm{~g}\end{array}$




$\begin{array}{ll}\text { VSOH }\left(524^{\circ} \mathrm{C} \text { - from PFL }\right) & 272 \mathrm{~g} \\ \text { VSB }\left(316^{\circ} \mathrm{C}+\text { from EO) }\right. & 100 \mathrm{~g}\end{array}$

These feed rates were attained at 1400 hours on Period 7 when the vacuum still products became available. However, the viscosity of the above blend was too high and it required more than 10 hours to obtain a uniform slurry fod blend. As a result, the cut point of vacuum still was lowered to ease the feed blending Starting fom Period 8 orly two distillation fractions were collected from the PFL in vacuum still, with the cut point initially set at $371^{\circ} \mathrm{C}$. This Downstream Product Flow Scheme is shown in Figure 3 . The hourly feed blend was changed to:

$\begin{array}{ll}\text { Coal }(\text { HTI-645S) } & 1627 \mathrm{~g} \\ \text { PFC } & 380 \mathrm{~g} \\ \text { VSB }\left(413^{\circ} \mathrm{C}+\text { from PFL) }\right. & 916 \mathrm{~g} \\ \text { VSB }\left(316^{\circ} \mathrm{C}+\text { from EO) }\right. & 25 \mathrm{~g}\end{array}$

The vacuum still cut point was increased to $385^{\circ} \mathrm{C}$ in Period 9, to $413^{\circ} \mathrm{C}$ in Period 10 , and to $427^{\circ} \mathrm{C}$ in Period 11. Also in Period 11, the O-1 temperature was increased from 335 to $343^{\circ} \mathrm{C}$. In Period 12 , in response to a very viscous feed (up to $3000 \mathrm{cp}$ at $116^{\circ} \mathrm{C}$ ) and feed pumping problens, $100 \mathrm{~g} / \mathrm{h}$ VSOH was added to the charge for 5 hours until VSB at a lower, $413^{\circ} \mathrm{C}$, cut point became available at 1300 hours. Therefore, it was never possible during Condition 2, even Conditions 3 and 4, to remove distillate stream with a boiling range $\left(343-524^{\circ} \mathrm{C}\right.$ ) equivalent to the foreign agglomerating oil used to prepare the agglomerated coal feed.

Condition 2 was extended for one day in order to obtain a smooth work-up period.

\section{Process and Equipment Operations}

There were numerous feed stoppages during Condition 2, with extended feed outages (greater than 10 minutes) in Periods 7,10 , and 11. The stoppages were usually the restult of problems at the feed pump checks, but others were due to lass of shurry circulation. Wash oil was added when necessary to regain flow, and buffer oil (VSOH) was used to maintain reactor feed during the extended feed outages. (Wash oil was L-814 until 1100 hours of Period 11 when the wesh pot was drained and filled with nun-generated VSOH) Feed stoppages became less fiequent at the end of Period 12 after the P-2 temperature was decreased from 127 to $116^{\circ} \mathrm{C}$ to more closely match the slurry preparation temperature.

\section{Condition 3 (Periods 14 through 17)}

In Condition 3 the catalyst addition rate was decreased from 112 to $79 \mathrm{~g} / \mathrm{h}$ for the iron catalyst and from 0.39 to $0.27 \mathrm{~g} / \mathrm{h}$ for the Molyvan A catalyst. An additional PFL out at $343^{\circ} \mathrm{C}$ was made with the vacuum still As shown in the Downstream Product Flow Scheme, Figure 4, the $\mathrm{IBP}-343^{\circ} \mathrm{C}$ fraction of the PFL $\left(\mathrm{VSOH}_{1}\right)$ was removed as product and the 343-413 ${ }^{\circ} \mathrm{C}$ fraction $\left(\mathrm{VSOH}_{2}\right)$ was 
used as buffer oils and diluent when needed. Starting from Period 15, the vacum still cut point was increased by $5^{\circ} \mathrm{C}$ to make the VSB IBP closer to $413^{\circ} \mathrm{C}$ and to decrease the net VSB yield.

There were occasional feed stoppages in every period of condition 3. The stopgages were usually very brief, and none were longer than 10 minutes.

In Period 15, the sluny feed circulator and HTU feed pump were taken off-tine for repacking. In Period 17 the water pump for the 0.1A separator was cleaned and rebuit. Also, the level control valve for the $O-t$ separator stuck open, causing the unit back-pressure to decrease by 350 psig with no impact on unit operations.

\section{Condition 4 (Periods 18 through 20 )}

In condition 4 the space velocity was decreased from 561 to $401 \mathrm{~kg} \mathrm{dry}$ coal/ $/ \mathrm{m} / \mathrm{m}^{3}$ (ea. reactor). Accordingly, the hourly feed rates were:

$\begin{array}{ll}\text { Oit Agglomerated Coal (HTI-6455) } & 1162 \mathrm{~g} \\ \text { PFC } & 271 \mathrm{~g} \\ \text { VSB from PFL }\left(412^{\circ} \mathrm{C}\right) & 654 \mathrm{~g} \\ \text { EO VSB }\left(343^{\circ} \mathrm{C}+\right) & 18 \mathrm{~g} \\ \text { Fe Cntayst } & 56 \mathrm{~g} \\ \text { Molyvan-A } & 0.19 \mathrm{~g} \\ \text { TNPS } & 64 \mathrm{~g}\end{array}$

These feed rate changes were completed by 1100 hours of Period 18.

The 0-3 safety relief valve was replaced in Period 18 when it was leaking vapors, the feed sturty circulation pump packing was tightened in Pexiod 19 after a significant leak, and the coupling for the HTU pump was replaced in Period 19.

\section{Condition 5 (Perjods 21 through 25)}

Operating Conditions, Procectures and Changes

In Condition 5, the coal feed was changed back to the raw coal at $1068 \mathrm{gm} / \mathrm{hr}$. The recycle material included dewaxed, hydrotreated VSOH (343 'C+). Figure 5 presents the Downstream Product Flow Scheme for Condition 5 . The dewaxing and hydrotreating steps were performed as previously described for preparing the initial DW-HT VSOH, except that the hydrotreater was operated at $360^{\circ} \mathrm{C}$ with a fed rate of $650 \mathrm{~g} / \mathrm{h}$ The other recycle components were PFC $(320 \mathrm{~g} / \mathrm{h}), 524^{\circ} \mathrm{C}+$ solids-free VSB $(437 \mathrm{~g} / \mathrm{h})$, and $371^{\circ} \mathrm{C}+\mathrm{EO}$ VSB $(20 \mathrm{~g} / \mathrm{h})$. These feed changes were completed by 1100 hours Period 21. 
The downstream processing required about two days to complete. As a result, preprepared DW-HT VSOH from previous runs with Black Thunder coal was used until the material from Condition 5 becarme available during Period 23. This material was also used in most of Period 24 to save the DWHT VSOH for the work up Period 25. However, because of prolonged pressure filtration times, there was still not enough DW-HT VSOH produced during the run for the entire Period 25.

Starting from Petiod 22, there were insufficient VSB available for the specified recycle. All VSBs produced were recycled, and DW-HT VSOH was recycled at a rate to maintain the total VSB-phusDW-HT VSO at $1102 \mathrm{gm} / \mathrm{hr}$. Also starting fron Period 23, the DW-HT VSOH was substituted for the EOVSB since it was not available. In Period 24, the sum of VSB and DW-HT VSOH was decteased to $1050 \mathrm{gm} / \mathrm{hr}$ to account for wax yield and $343^{\circ} \mathrm{C}$ - rejected.

Process and Equipment Operations

At the beginning of Period 21 there were difficulties in maintaining usit feed. Vaporization of light material in the circulating lines were partly responsible. During the rest of Condition 5 there were occasional, very brief feed stoppages.

In Period 22 the upper heater of the in-line hydrotreater failed. The middle temperature decreased by about $93^{\circ} \mathrm{C}$ for 3 hours until it was replaced.

\section{On-Line Time Summary}

The chronology of the operations for Run ALC-1 is listed in Table 32 along with a summary of the total time in startup, nun, shutdown, and down modes. Unit 227 operated for 694 hours with one interuption during startup for an On-Line Eficiency of $97.2 \%$.

\section{Shutdown and Inspection}

Shutdown commenced at the end of Period 25 (0400 hours May 14, 1996). It went through very smoothly. All of the process equipment was in order; only routine maintenance was required 
Appendix G. Boiling Point Distribution of First and Second Stage Overheads

\begin{tabular}{|c|c|c|c|c|c|c|c|c|c|c|c|c|}
\hline \multirow[b]{3}{*}{ Vol\% / Period } & \multicolumn{5}{|c|}{ Temperature [degree F] } & \multicolumn{7}{|c|}{ Temperature [degree F } \\
\hline & \multicolumn{5}{|c|}{ First Stage Overheads } & \multicolumn{7}{|c|}{ Second Stage Overheads } \\
\hline & 6 & 13 & 17 & 20 & 25 & $\mathbf{5}$ & 8 & 12 & 13 & 17 & 20 & $\mathbf{2 5}$ \\
\hline 0.5 & 130 & 123 & 99 & 137 & 98 & 44 & 37 & 41 & 84 & B7 & 97 & 47 \\
\hline 5.0 & 209 & 207 & 198 & 217 & 188 & 175 & 163 & 165 & 174 & 172 & 170 & 171 \\
\hline 10.0 & 204 & 259 & 250 & 260 & 240 & 201 & 243 & 100 & 201 & 196 & 209 & 200 \\
\hline 15.0 & 286 & 275 & 269 & 290 & 268 & 228 & 274 & 215 & 225 & 220 & 239 & $22 B$ \\
\hline 20.0 & 305 & 291 & 287 & 315 & 288 & 254 & 304 & 241 & 240 & 244 & 284 & 257 \\
\hline 25,0 & 326 & 307 & 305 & 339 & 309 & 281 & 335 & 264 & 267 & 285 & 273 & 270 \\
\hline 30,0 & 347 & 322 & 322 & 364 & 329 & 307 & 365 & 272 & 275 & 272 & 286 & 280 \\
\hline 35.0 & 367 & 338 & 340 & 380 & 349 & 334 & 393 & 282 & 204 & 281 & 311 & 292 \\
\hline 40.0 & 394 & 372 & 358 & 415 & 385 & 360 & 420 & 297 & 303 & 295 & 342 & 323 \\
\hline 45.0 & 423 & 396 & 386 & 443 & 418 & 394 & 443 & 324 & 329 & 322 & 372 & 357 \\
\hline 50.0 & 451 & 423 & 415 & 469 & 453 & 428 & 465 & 350 & 360 & 349 & 402 & 393 \\
\hline 55.0 & 479 & 451 & 445 & 493 & 487 & 458 & 487 & 386 & 391 & 385 & 433 & 430 \\
\hline 60,0 & 505 & 481 & 474 & 518 & 519 & 488 & 508 & 418 & 423 & 417 & 461. & 467 \\
\hline 65.0 & 532 & 510 & 503 & 543 & 548 & 515 & 528 & 452 & 459 & 450 & 491 & 501 \\
\hline 70.0 & 559 & 543 & 530 & 569 & 571 & 540 & 547 & 487 & 494 & 486 & 521 & 532 \\
\hline 75.0 & 584 & 580 & 570 & 599 & 590 & 568 & 567 & 525 & 530 & 523 & 552 & 569 \\
\hline 20.0 & 610 & 829 & 015 & 037 & 624 & 592 & 589 & 583 & 567 & 563 & 582 & 588 \\
\hline 86.0 & 652 & 675 & 664 & 671 & 652 & 625 & 617 & 606 & 613 & 507 & 624 & 620 \\
\hline 90,0 & $6 B 7$ & 718 & 707 & 708 & 680 & 685 & 653 & 684 & 670 & 866 & 671 & 656 \\
\hline 95.0 & 734 & 769 & 759 & 755 & 720 & 712 & 698 & 726 & 733 & 729 & 729 & 698 \\
\hline 99.5 & 632 & 860 & 840 & 046 & 804 & 813 & 799 & 627 & 636 & 629 & 828 & 787 \\
\hline
\end{tabular}


Appendix H: Composition of SOH Water Products from Run ALC-I

\begin{tabular}{|c|c|c|c|c|c|}
\hline \multicolumn{2}{|c|}{ SOH Water Sample Source } & \multirow[b]{2}{*}{ pH } & \multicolumn{3}{|c|}{ Elemental Composition, $w$ \% of Sample } \\
\hline Perlod & Stage & & s(a) & $N(b)$ & $C_{\text {(b) }}$ \\
\hline $6 \mathrm{~B}$ & $1 s t$ & 9.22 & 0.79 & $\begin{array}{r}1.52 \\
\end{array}$ & 1.72 \\
\hline $\begin{array}{r}13 \mathrm{~B} \\
13 \mathrm{~B} \\
\end{array}$ & $\begin{array}{l}1 \text { st } \\
\text { 2nd }\end{array}$ & $\begin{array}{r}9.07 \\
9.74 \\
\end{array}$ & $\begin{array}{r}1.24 \\
2.69 \\
\end{array}$ & $\begin{array}{r}1.77 \\
2.14 \\
\end{array}$ & $\begin{array}{l}1.84 \\
0.54 \\
\end{array}$ \\
\hline $\begin{array}{l}178 \\
17 \mathrm{E} \\
\end{array}$ & $\begin{array}{l}\text { 1st } \\
\text { 2nd }\end{array}$ & $\begin{array}{l}9.19 \\
9.21 \\
\end{array}$ & $\begin{array}{l}1.07 \\
2.50 \\
\end{array}$ & $\begin{array}{r}1.43 \\
2.00 \\
\end{array}$ & $\begin{array}{r}1.69 \\
0.27 \\
\end{array}$ \\
\hline $\begin{array}{l}20 \mathrm{~B} \\
20 \mathrm{~B}\end{array}$ & $\begin{array}{l}1 s t \\
2 n d\end{array}$ & $\begin{array}{r}9.02 \\
9.29 \\
\end{array}$ & $\begin{array}{l}1.05 \\
2.52 \\
\end{array}$ & $\begin{array}{r}1.46 \\
1.85 \\
\end{array}$ & $\begin{array}{l}1.70 \\
0.12 \\
\end{array}$ \\
\hline $\begin{array}{r}25 B \\
258 \\
\end{array}$ & $\begin{array}{r}1 s t \\
2 n d\end{array}$ & $\begin{array}{r}8.94 \\
9.09 \\
\end{array}$ & $\begin{array}{l}0.66 \\
2.22 \\
\end{array}$ & $\begin{array}{l}1.25 \\
1.63 \\
\end{array}$ & $\begin{array}{r}\mathbf{1 . 7 1} \\
\mathbf{0 . 1 5} \\
\end{array}$ \\
\hline
\end{tabular}

(a) Total S analysis by LECO SC-32 Sulfur Analyzer

(b) $\mathrm{C}$ and $\mathrm{N}$ analysis by LECO $\mathrm{CH} \mathrm{N}-1000$

Note: Analysis Performed by CONSOL, lac 


\section{Appendix I: Impact of Carbon Loss in SOH Water on Distillate Yield}

\author{
DATE \\ PERIOD \\ Cod Type or Bag *s \\ COADITION
}

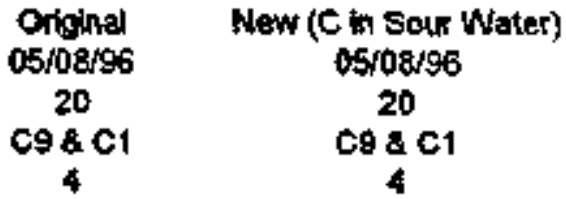

NET NORMALIZED YIELDS, W\% maf coal

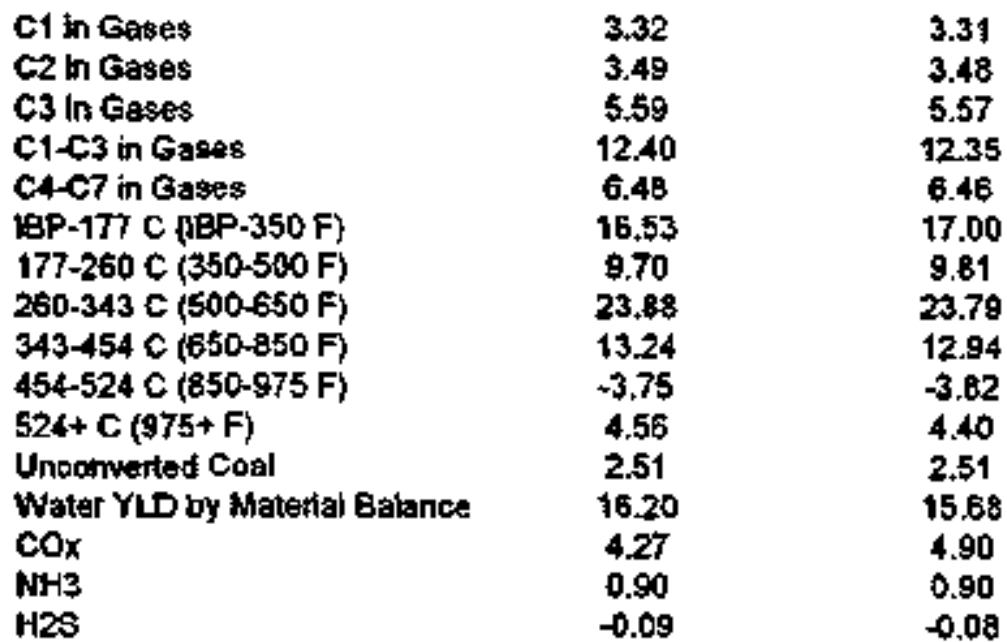

\section{PROCESS PERFORMANCE, W\% maf coal}

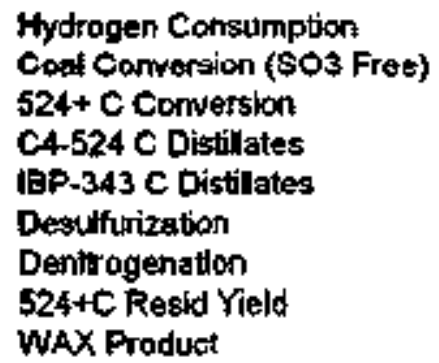

$\begin{array}{cc}6.8 & 6.8 \\ 97.5 & 97.5 \\ 82.9 & 93.1 \\ 66.1 & 66.2 \\ 50.1 & 50.6 \\ 78.6 & 76.7 \\ 70.9 & 71.3 \\ 4.6 & 4.4\end{array}$

6.8

93.1

66.2

78.7

71.3

4

\section{PROCESS CONDITIONS}

Space Velocity, mf cosl / reactor volume

$\mathrm{K}-1$ (tohr $/ \mathrm{ft} 3)$

$\mathrm{K}-2$ (b/hr/ft3)

26.1

26.1

628.9

846.3

$\mathrm{K}-2$

Frest

mpin mi coal

Mo in Molyan A

68

6811 
APPENDIX J: Properties of Recycle Solvents and PFC (dally analysis)

\begin{tabular}{|c|c|c|c|c|c|c|c|c|c|c|c|c|c|}
\hline $\begin{array}{l}\text { Period } \\
\text { Date }\end{array}$ & $\underset{4 / 19}{J}$ & $\underset{4 / 20}{2}$ & $\begin{array}{c}3 \\
4 / 21\end{array}$ & $\begin{array}{c}4 \\
4 / 22\end{array}$ & $\begin{array}{c}5 \\
4 / 23\end{array}$ & $\begin{array}{c}6 \\
4 / 24\end{array}$ & $\begin{array}{c}7 \\
4 / 25\end{array}$ & $\begin{array}{c}8 \\
4 / 26\end{array}$ & $\begin{array}{c}9 \\
4 / 27\end{array}$ & $\begin{array}{c}10 \\
4 / 2 B\end{array}$ & $\begin{array}{c}11 \\
4 / 29\end{array}$ & $\frac{12}{4 / 30}$ & $\begin{array}{l}\mathbf{1 3} \\
5 / 1\end{array}$ \\
\hline $\begin{array}{l}\text { PFL: } \\
\text { IBP, }{ }^{\circ} \mathrm{C} \\
\text { IBP-343 } \\
343-454 \\
454-524 \\
524 C^{*} \\
\text { LOSs } \\
\text { VSOH: } \\
\text { 1BP."C } \\
1 \mathrm{BP}-343 \\
343-454 \\
454-524 \\
524 C^{+} \\
\text {Loss } \\
\text { VSB } \\
\text { 1BP, C } \\
\text { iBP-343 } \\
343-454 \\
454-524 \\
524 C^{*} \\
\text { Loss }\end{array}$ & & $\begin{array}{c}245 \\
8.44 \\
51.38 \\
14.50 \\
24.95 \\
0.73\end{array}$ & $\begin{array}{c}239 \\
10.15 \\
47.69 \\
14.23 \\
27.29 \\
0.64\end{array}$ & $\begin{array}{c}253 \\
9.91 \\
47.32 \\
14.11 \\
28.21 \\
0.45\end{array}$ & $\begin{array}{c}218 \\
13.34 \\
47.09 \\
12.26 \\
26.68 \\
0.63\end{array}$ & $\begin{array}{c}218 \\
17.43 \\
40.47 \\
12.65 \\
28.91 \\
0.54\end{array}$ & & $\begin{array}{c}211 \\
15.27 \\
45.16 \\
14.63 \\
24.31 \\
0.63 \\
\\
\\
221 \\
63.7 \\
35.4 \\
0.7 \\
0.0 \\
0.2 \\
\\
\\
352 \\
0.0 \\
51.37 \\
16.80 \\
31.39 \\
0.44\end{array}$ & $\begin{array}{c}218 \\
68.31 \\
30.98 \\
0.7 \\
0.0 \\
0.0 \\
\\
\\
390 \\
0.0 \\
44.54 \\
21.14 \\
34.06 \\
0.26\end{array}$ & $\begin{array}{c}219 \\
51.5 \\
47.7 \\
0.8 \\
0.0 \\
0.0 \\
\\
\\
368 \\
0.0 \\
41.44 \\
17.90 \\
40.23 \\
0.0\end{array}$ & $\begin{array}{c}227 \\
36.55 \\
62.35 \\
0.7 \\
0.0 \\
0.4 \\
\\
\\
403 \\
0.0 \\
30.91 \\
21.44 \\
47.14 \\
0.51\end{array}$ & $\begin{array}{c}220 \\
37.33 \\
61.98 \\
0.4 \\
0.0 \\
0.29 \\
\\
\\
393 \\
0.0 \\
34.20 \\
22.48 \\
42.81 \\
0.51\end{array}$ & $\begin{array}{c}226 \\
53.8 \\
45.1 \\
0.9 \\
0.0 \\
0.2 \\
\\
\\
373 \\
0.0 \\
41.63 \\
19.11 \\
38.91 \\
0.35\end{array}$ \\
\hline $\begin{array}{l}\text { Ql on } \\
\text { PFCs } \\
\text { ASTMash } \\
S \text { in ash }\end{array}$ & $\begin{array}{c}71.09^{*} \\
37.94 \\
--\end{array}$ & $\begin{array}{l}81.94 * \\
57.88 \\
9.50\end{array}$ & $\begin{array}{c}86.62 * \\
59.92 \\
9.81\end{array}$ & $\begin{array}{l}76.53^{*} \\
56.03 \\
9.82\end{array}$ & $\begin{array}{l}81.89 * \\
61.52 \\
9.66\end{array}$ & $\begin{array}{c}85.21 * \\
63.44 \\
10.0\end{array}$ & $\begin{array}{c}59.50 \\
43.97 \\
7.62\end{array}$ & $\begin{array}{c}63.23 \\
45.94 \\
5.33\end{array}$ & $\begin{array}{c}54.85 \\
42.59 \\
3.01\end{array}$ & $\begin{array}{c}61.43 \mathrm{a} \\
44.99 \\
5.01\end{array}$ & $\begin{array}{c}62.76 \\
47.04 \\
4.48\end{array}$ & $\begin{array}{c}58.94 \\
\$ 6.04 \\
3.22\end{array}$ & $\begin{array}{c}55.24 \\
\\
40.97 \\
3.0\end{array}$ \\
\hline
\end{tabular}




\begin{tabular}{|c|c|c|c|c|c|c|c|c|c|c|c|c|}
\hline $\begin{array}{l}\text { Period } \\
\text { Date }\end{array}$ & $\begin{array}{l}14 \\
5 / 2\end{array}$ & $\begin{array}{r}15 \\
5 / 3\end{array}$ & $\begin{array}{l}16 \\
5 / 4\end{array}$ & $\begin{array}{l}17 \\
5 / 5\end{array}$ & $\begin{array}{c}18 \\
5 / 6\end{array}$ & $\begin{array}{c}19 \\
5 / 7\end{array}$ & $\begin{array}{l}20 \\
5 / 8\end{array}$ & $\begin{array}{l}21 \\
5 / 9\end{array}$ & $\begin{array}{c}22 \\
5 / 10\end{array}$ & $\begin{array}{c}23 \\
5 / 11\end{array}$ & $\begin{array}{c}24 \\
5 / 12\end{array}$ & $\begin{array}{c}25 \\
5 / 13\end{array}$ \\
\hline $\begin{array}{l}\text { DW-HT } \\
\text { YSOH1 } \\
\text { IBP, }{ }^{\circ} \mathrm{C} \\
\text { IBP-343 } \\
343-454 \\
454-524 \\
524 C^{+} \\
\text {Loss } \\
\text { DW-HT } \\
\text { VSOH12 } \\
\text { IBP, }{ }^{\circ} \mathrm{C} \\
\text { IBP-343 } \\
343-454 \\
454-524 \\
524 C^{+} \\
\text {Loss } \\
\text { YSB } \\
\text { IBP. } \\
\text { IBP- C } \\
343-454 \\
454-524 \\
524 C^{+} \\
\text {Loss }\end{array}$ & & $\begin{array}{c}263 \\
28.73 \\
70.80 \\
0.0 \\
0.0 \\
0.39 \\
\\
\\
388 \\
0.0 \\
38.99 \\
22.70 \\
38.04 \\
0.27\end{array}$ & $\begin{array}{c}245 \\
35.21 \\
63.41 \\
0.89 \\
0.0 \\
0.49 \\
\\
\\
380 \\
0.0 \\
39.86 \\
21.68 \\
38.20 \\
0.26\end{array}$ & $\begin{array}{c}203 \\
82.85 \\
16.94 \\
0.0 \\
0.0 \\
0.21 \\
\\
\\
245 \\
35.90 \\
63.12 \\
0.69 \\
0.0 \\
0.29 \\
\\
\\
373 \\
0.0 \\
39.20 \\
18.29 \\
42.07 \\
0.44\end{array}$ & & $\begin{array}{c}243 \\
23.66 \\
75.66 \\
0.68 \\
0.0 \\
0.0 \\
\\
397 \\
0.0 \\
33.68 \\
22.22 \\
43.58 \\
0.52\end{array}$ & $\begin{array}{c}227 \\
54.25 \\
45.65 \\
0.0 \\
0.0 \\
0.1 \\
\\
\\
262 \\
9.71 \\
90.0 \\
0.0 \\
0.0 \\
0.39 \\
\\
\\
389 \\
0.0 \\
36.58 \\
18.33 \\
44.74 \\
0.35\end{array}$ & $\begin{array}{c}185 \\
75.44 \\
23.5 \\
1.06 \\
0.0 \\
0.0 \\
\\
\\
305 \\
5.1 \\
86.7 \\
6.53 \\
1.57 \\
0.0\end{array}$ & $\begin{array}{c}142 \\
83.1 \\
16.9 \\
0.0 \\
0.0 \\
0.0 \\
\\
\\
274 \\
14.9 \\
75.3 \\
7.94 \\
1.86 \\
0.0 \\
\\
\\
509 \\
0.0 \\
0.0 \\
7.54 \\
91.97 \\
0.49\end{array}$ & $\begin{array}{c}19 . \\
85.30 \\
11.7 \\
2.95 \\
0.0 \\
0.0 \\
\\
\\
330 \\
5.12 \\
76.7 \\
16.4 \\
1.47 \\
0.29 \\
\\
497 \\
0.0 \\
0.0 \\
10.25 \\
89.34 \\
0.41\end{array}$ & $\begin{array}{c}197 \\
77.52 \\
29.27 \\
0.21 \\
0.0 \\
0.0 \\
\\
\\
333 \\
5.17 \\
77.6 \\
14.52 \\
2.03 \\
0.68 \\
\\
\\
507 \\
0.0 \\
0.0 \\
7.71 \\
91.72 \\
0.57\end{array}$ & $\begin{array}{c}181 \\
64.27 \\
33.13 \\
2.60 \\
0.0 \\
0.0\end{array}$ \\
\hline $\begin{array}{l}\text { Ql on PFC } \\
\text { ASTM ash } \\
S \text { in ast }\end{array}$ & $\begin{array}{c}56.92 \\
41.71 \\
2.47\end{array}$ & $\begin{array}{c}60.34 \\
43.05 \\
3.57\end{array}$ & $\begin{array}{c}61.66 \\
42.06 \\
3.28\end{array}$ & $\begin{array}{c}63.45 \\
43.06 \\
3.4 \mathrm{I} \\
\end{array}$ & $\begin{array}{c}61.85 \\
43.72 \\
3.92\end{array}$ & $\begin{array}{c}64.88 \\
45.02 \\
3.35\end{array}$ & $\begin{array}{c}39.96 \\
41.78 \\
3.29\end{array}$ & $\begin{array}{c}62,58 \\
43.76 \\
2.85\end{array}$ & $\begin{array}{l}66.78 \\
4.26 \\
7.46\end{array}$ & $\begin{array}{c}60.21 \\
42.70 \\
9.26\end{array}$ & $\begin{array}{c}46.79 \\
34.38 \\
9.30\end{array}$ & $\begin{array}{l}53.92 \\
40.15 \\
10.80\end{array}$ \\
\hline
\end{tabular}

*Toluene extracled PFC 


\section{Appendix K: SPECIAL SAMPLES FOR CONSOL INC.}

\section{COLLECTION PERIODS - 6, 13, 17, 20, \& 25}

SAMPLE STREAM

Hydrotreated SOH Oil (2nd stage)

SOH water (2rd stage)

]st stage SOH

(Collected inmediately after W-sp period)

ASOH

PFL (period 5 only)

PFC (toluene extracied)

PFC

VSOH(from PFL)

VSB(rom PFL)

Dewaxed VSOH

Wax

Hydrotreated Dewaxed VSOH

CAS BOTTOMS (all W-up periods)

FEED SLURRY (all W-ups)

INTERSTAGE SLURRY SAMPLE(after W-up)

L-814 (once per run)
AMOUNT.GM

2 gal

250

50

50

150

150

50

100

100

100

350

100

150

200

150

200 
SECTION THREE

\author{
LDP Associates
}


Dr. Ed Givens

November 12,1996

Center for Applied Energy Research

3572 Iron Works Pike

Lexington, Kentucky $40511-8433$

Dear Ed:

Subject: QUARTERLY PROGRESS REPORT: JULY THRU SEPTEMBER 1996

For the quarter ending September 30, 1996 the following subcontract services (UKRF-425582-92-75) were performed in support of the DOE Advanced Concepts Program (DE-AC22-91PC91040):

\section{ALC-1 ANALYSIS}

The elementaily balanced material balance procedure was used to calculate estimated yields, hydrogen consumption and distillate boiling range yields for Period $\# 12$ of Condition $\# 2$. As expected $\mathrm{C}_{4}+$ distillate yield increased significantly versus the original Condition $\# 2$ material balance Period (\#13). This preliminary result was later confirmed by HTl's similar finding.

The analysis of the Separator Overbead Water (SOH) samples for the five conditions was received from $\mathrm{CONSOL}$ and reviewed. A method was developed for incorporating these analysis into HTI's normalized material balance, but an assumption regarding the inorganic carbon content of the SOH was also required. The method was discussed with both CONSOL and HTI and was used to provide a fully nomalized HTI material balance for one of the conditions. The effect of including the $\mathrm{SOH}$ water in the normalized balance was not significant.

Based on metals analysis performed by CONSOL a molybdenum balance was calculated for Conditions \#2 thru \#5 of the rin. The results indicate the moly leaving the unit was much greater than the reported moly input. The reason for this apparent inconsistency is being investigated.

Comments on HTI's draft nun report were prepared and transmitted. A request was made for the preparation, in the future, of a simplified but comprehensive printout of the input and output of HTI's normalized material balances.

\section{ALC-2 RUN PLAN}

The first draft of the run plan was reviewed and comments were discussed with Ed Givens. A suggestion was made to lower the recycle solvent to 
coal ratio to approximately $1.8 / 1$ for the high solids recycle periods. The revised backend distillation system was also reviewed.

A subsequent second draft of the ran plan was reviewed and comments were discussed with CONSOL and CAER.

\section{REACTOR MODELING}

In response to questions raised by Prof. Grulke ( $U$ of $K$ ), an information package was prepared to assist in the development of the above ASPEN based model. Questions on resid properties, material balance methods and reactor operating parameters \& yields were addressed.

\section{ECONOMJC ASSESSMENT}

No activity.

cc: F. Derbyshire @ CAER

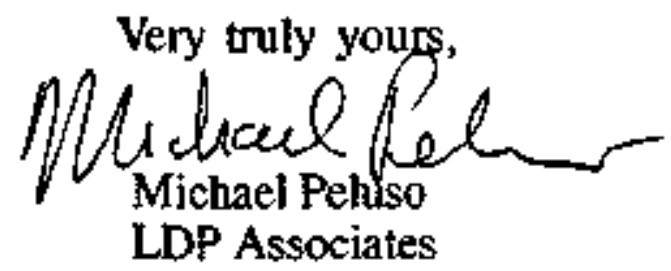

R. Anderson @ CAER

R. Winschel @ CONSOL

T. Lee@ HTI 


\section{SECTION FOUR}

CONSOL, Inc 
February 6, 1997

Report Period: July 1 - September 30, 1996

\section{SUBCONTRACT TITLE AND NUMBER:}

Subcontract UKRF-4-25582-92-76 to CONSOL inc.

Under DOE Contract No. DE-AC22.91PC91040, "Advanced Coal Liquefaction Concepts for the PETC Generic Bench-Scale Unit"

\section{SUBCONTRACTOR NAME: \\ CONSOL Inc. \\ Research \& Development \\ 4000 Brownswille Rpad \\ Library, PA 15129}

SUBCONTRACT PER OO: November 26, 1991 - February 28, 1997 (future extension to September 30, 1998, expected)

PRINCIPAL INVESTIGATORS: R. A. Winschel, G. A. Robbins

SUBCONTRACT OBJECTIVES: No change.

\section{SUMMARY OF TECHNICAL PROGRESS - OVERALL}

Most of the activities this quarter were directed toward evaluation of Run ALC-1 results and planning for Run ALC-2. The process oil semples collected during Run ALC-1 were characterized by CONSOL under DOE Contract DE-AC22-94PC93054. Anzlyses showed that about $1 \%$ of the feed coal carbon reports to the separator overtead water product. It appears that any error resulting from omitting this stream from elementai balance calculations shoutd be small. There had been concern that significant amounts of light oils were recycled in Run ALC-1. However, the analysis of feed sturty samples showed that they contained less than $5 \% 343^{\circ} \mathrm{C}-$ $\left(650^{\circ} \mathrm{F}\right)$ material. The concentrations of $\mathrm{Mo}$ and $\mathrm{Fe}$ in feed sturry and pressure filter cake ash samples were used to address catalyst issues within Run ALC-1. The Mo and Fe concentration results were combined with HTI material balance data for Run ALC-1 to calculate Mo and $\mathrm{Fe}$ batances and determine the apparent addition rates of Mo and Fe calalysts. The resulting Mo and $\mathrm{Fe}$ material balance closures were between $80-120 \%$. The results indicate that the Mo addition rate was inedvertently $10-169 \%$ higher than the target rate. The highest Mo addition rate was during agglomerated coal feed periods. The results show a low $F$ addition rate in Period 13 (39\% of the target rate), and $4 \%$ to $36 \%$ higher than design rate in the other periods. The analysis of vactum disfillates from Run ALC-1 indicate that the bench-unit dewaxing operations 
effectively removed paraffins from the vacuum distillate. However, the low concentration of wax in the feed minimized the impact of dewaxing on solvent quality improvernent. The solvent hydrobreating operation effectively hcreased the hydroaromatic hydrogen content of the distilate and improved its solvent quality. The wax product from Run ALC-1 was characterized; it has a purity of about 75\%. CONSOL participated in planning for Run ALC-2. A paper on the results of Run ALC-1 was presented at the DOE Contractors Review Conference and at the Thirteenth Annual international Pittsburgh Coal Conference.

Activites planned for next quarter include completion of the elemental and material batances for the aggiomerate production nus, planning and on-site support for Run ALC-2, and initial planning for Rum ALC-3.

\section{SUMMARY OF TECHNICAL PROGRESS - BY TASK}

\section{Task 2 - Laboratory Support}

The process oll and water samples collected during Run ALC-1 are being characterized by CONSOL under DOE Contract DE-AC22-94PC93054.

\section{Analysis of Separator Ovenead (SOH) Water Samples From Run ALC-1}

The analyses of Run ALC-1 SOH waler samples were completed. Samples from both Stage 1 and Stage 2 were analyzed for pH and weight percent $C, N$, and S (Table 1) for HTI's elernents! balances. Relative to the Stage 1 samples, the Stage 2 samples had generally higher $\mathrm{pH}$ and $S$ and $\mathrm{N}$ concentrations, and lower $\mathrm{C}$ concentration. At the SOH water product flow rates in Run ALC-1 (about $14 \mathrm{~kg} / \mathrm{day}$ ), the carton content in the water is about 210 grday (depending on the production split between the two stages). At the coal feed rate of Run AlC-1 (about $26 \mathrm{~kg} / \mathrm{day}$ ). the coal carbon feed rate is about $16.6 \mathrm{~kg} / \mathrm{day}$. Based on this analysis, about $1 \mathrm{wt} \%$ of the coal cathon and somewhat greater proportions of the coal sulfur and nitrogen report to the SOH water. It appears that any eror resulting from omitting this stream from elemental balance calculations should be small.

The phenolic compounds in one $\mathrm{SOH}$ water sample (Period 13B, first stage) were nonquantitatively characterized by GC/MS analyses. The procedure used was acidification of the sample with $\mathrm{HCl}$ from a pH of about 9 to a pH of about 1 and extracton of the tar acids with methylene chioride. The appearance of the liquid changed from clear, bright yellow to coiortess 
and stightly turtid upon acidication. Odors delected during acitification (in chronological order) included $\mathrm{H}_{2} \mathrm{~S}, \mathrm{SO}_{2}$, and phenols. Only phenal and the cresols were identified in the tar acids.

\section{Determination of Light Oil Contents of Feed Slurry Samodes from Run ALC-1}

There had been concem that significant amounts of Itght oils were recycled during Run ALC-1, the to inefficient distilation and other operating conditions. To address this concom, feed slumy samples from each condition of Run ALC-1 were distilled to $343^{\circ} \mathrm{C}\left(650^{\circ} \mathrm{F}\right)$ and $524{ }^{\circ} \mathrm{C}$ (975 ${ }^{\circ}$ F). The resid was extracted with tetratydrofuran, and ashed to determine other components as shown in Table 2. An important result from this characterization is that onty a small quantity of $343^{\circ} \mathrm{C}$ ( $\left(650^{\circ} \mathrm{F}\right.$ ) material was recycled in Run ALC-1 ( $55 \%$ of feed slumy). This presumes that no light material was lost from the samples which were distlled by CONSOL.

\section{Determination of Dispersed Catalyst Concentrations in Run ALC-1}

Mo and Fe concentrations in the second-stage pressure-filter cake (PFC) samples from Run ALC-1 were detemined. They are presented in Table 3 on three bases: (1) metal oxide as welght percent of the $\mathrm{SO}_{3}$-containing ash; (2) element as a weight percent of the $\mathrm{SO}_{3}$-free ash; and (3) element as a weight percent of the $\mathrm{SO}_{3}$-containing ash. The CONSOL Mo values are in good agreement with those reported by $\mathrm{HTT}$ for the second-stage pressure-filter cake. However, many of CONSOL's Fe values are $20 \%$ or more higher than those reported by HTI.

Mo and Fe concentrations were also determined in the $524^{\circ} \mathrm{C}^{+}\left(975^{\circ} \mathrm{F}\right)$ resids from all of the Run ALC-1 feed siurry samples (Table 4). The data provide a direct measurement of the total Mo and Fe concentrations in the reactor feed. The concentrations of the metals in the ash agree weil with the pressure filter cake (PFC) results reported in Table 3. Elemental Mo concentrations for the entire set (PFC and feed slurry) ranged from 0.19 to $0.47 \mathrm{wt} \%$ of the $\mathrm{SO}_{3}$-free ash, and approximately doubled when agglomerated coal was fed (parthy in response to the reduced ash content of the aggiomerated coal). Fe concentrations for the entire set ranged from 17.9 to $28.1 \mathrm{wt} \%$ of the $\mathrm{SO}_{3}$-free ash, and decreased from Condtion 2 through the end of the run.

The Mo and Fe concentration results were combined with HTI material balance data to calculate Mo and $\mathrm{Fe}$ balances and determine the apparent addition rates of Mo and Fe catalysts. Intermediate and final calculated results are shown in Table 5. The following assumptions were used in the calcutations: raw coal $\mathrm{SO}_{3}$-free ash content of $5.50 \% \mathrm{MF}$; agglomerated coal $\mathrm{SO}_{3}$-tree ash content of $3.30 \% \mathrm{MF}$; added $\mathrm{Fe}_{2} \mathrm{O}_{3}$ was $1.4 \%$ or $0.98 \%$ of the MF coal rate (for calculating 
total ash fed to system); Mo in the raw or agglomerated coal was ignored (the MF raw or agglomerated coal contains $\mathrm{ca} .2 \mathrm{ppm} \mathrm{Mo}$ ); the $\mathrm{Fe}_{2} \mathrm{O}_{2}$ content of the raw coal $\mathrm{SO}_{3}$-free ash was $6.66 \%$; and the $\mathrm{Fe}_{2} \mathrm{O}_{3}$ content of the agglomerated coal $\mathrm{SO}_{3}$-frie ash was $9.57 \%$. These data were obtained from this report, the Aprit-June quarterly report for this contract, and HTI's run report.

The Mo and Fe balances were caculated for each of the periods shown as the ratio of total grams of Mo or Fe out to the total grams of Mo or Fe in. Total Mo or $\mathrm{Fe}$ in was oblained by multiplying the weight percent Mo or Fe in the feed slurry $\mathrm{SO}_{3}$-free ash by the grams of ash fed in that period in the fresh coal and fresh iron catalyst, and in the pressure-filter cake (PFC) recycle. The amount of ash fed in the tresh coat was obtained from the amount of MF coal fed (HTI tnaterial balance data) and the $\mathrm{SO}_{3}$-free ash content of the uncleaned or agglomerated coal. The ash fed in the added Fe catalyst was obtained as $1.4 \mathrm{Wt} \%$ of the amount of MF coal fed (for the 10,000 ppm Fe target addition rate), or as 0.98 wt \% of the amount of MF coal fed (for the 7,000 ppm Fo target addition rate). The ash led in the recycle PFC was obteined from HTI's recycle ratio of insolubie organic matter (1OM) plus $\mathrm{SO}_{3}$-free ash to MF coal, and HT's measurements of IOM and $\mathrm{SO}_{3}$-free ash contents of the PFC. The total amount of Mo or Fe out was obtained by multiplying the wt \% Mo or Fe in the PFC by the grams of total PFC produced for the period (HTI materia! balance dato).

Apparent catalyst addition rates were obtained by subtracting the arnount of Mo or Fe in the recycled PFC from the total amount of Mo or Fe fed in the feed siurry. The rates then were put on an MF coal basis. th the Fe case, the coal Fe cordrtitution was backed out, so that the results represent only added Fe. The ca. $2 \mathrm{ppm}$ Mo in the raw coal was not backed out.

The resulting Mo balances were $80-119 \%$, and the Fe balances were $98-120 \%$. These Indicate that the balances were generally good; that is, there was not a consistent or gross imbalance between foed and product rates. These balances generally verify the validity and consistency of the analytical measurements. The calculated apperent Mo catalyst addition rates (MF coal besis) were 110-269 ppmi Mo when the target Mo concentration was $100 \mathrm{ppm}$, and 94-161 ppm when the target rate was $70 \mathrm{ppm}$ Mo. The calculated apparent Fe catalyst addition rates (MF coal basis) were 3,928-13,642 ppm Fe when the target Fe concentration was 10,000 ppm, and 7,309-8,571 ppm when the target rate was 7,000 ppm Mo. 
These results show that the Mo added was $10-169 \%$ in excess of the target rate. The amount in excess seomed to be largest during periods when agglomerated coal was fed. The generally good Mo balance suggests that the Mo addition rate was inadvertently high, rather than being caused by introduction of Mo from a spurious source. Any spurious source of Mo would have to introduce a high Mo concentration in the feed slurry to be consistent with these results. The resulks show that the $\mathrm{Fo}$ added in Period 13 (Condition 2) was only $39 \%$ of the target rate, but in the other periods was $4-36 \%$ in excess of the target rate.

\section{Effectiveness of Dewaxing and Solvent Hydrotreating In Run ALC-1}

Vacuum distillates from Run ALC-1 wore dewaxed in the laboratory and the dewaxing feeds and fractions were anabzed (microautodave solverk quality and NMR) to deterrinine the effectiveness of the Run ALC-1 dewaxing and hydrotreating operations. The vacuum distillates tested were either vacuum still oventead (VSOH) samples or the laboratory-generated $454^{\circ} \mathrm{C}-\left(850^{\circ} \mathrm{F}^{-}\right)$ distillate of $0-6$ bottoms samples.

Table 6 shows that the $0-6$ bottoms distillate contained about $5-6 \%$ wax before dewaxing operations were started (Feriod 20). During operations with dewaxing (Period 25), the wax content of the second-stage heavy distillate (VSOH),product was reduced to 1-2\%, presumably mostly freshly produced wax. The heavy distilate (VSOH, dewaxed) also taken from period 25 but downstream of dewaxing was virtualfy devoid of wax.

The ${ }^{1} H$-NMR proton distributions and microautoclave sofvent quality test results of heavy distillates retevant to the dewaxing operations are shown in Table 7. The data are summarized in Table 8; averages and standard deviations are shown where possible. The data in Table 8 show that the parafinie nature of the heavy distiflate was reduced by dewaxing and there was a minor improvement in solvent quality, as measured by two types of microautodave liquefaction tests. Hydrotreating was effective in producing hydroaromatics and in improving solvent quality.

In summary, the results indicate that the bench-unit operations were quite effective in dewaxing the vacuum distillate. However, the kow concentration of wax in the feed limited the impact of the dewaxing on improving solvent quality. The solvent hydrotreating operation increased the hydroaromatic hydrogen content of the distillate and improved its solvent quality. 


\section{Analysis of Wax Produced in Run AlC-1}

The wax produced in period 25 of Run ALC-1 was characterized by elemental, 'H-NMR, end GCMMS analyses (Table 9). The wax was black and had a strong odor. The elemental analysis indicates that it contained over $\mathbf{4 3 \%}$ hydrogen; however, four replicete elemental analyses gave poor repeatability (about $5 \%$ felative). We assume that the reported carbon content (74 w \%) is Incorrectly low, because the "H-NMR and GCNMS anayses did not indicate major concentrations of any components exceps alkanes. The wax was de-ciled via our standard dewaxing procedure at $-5{ }^{\circ} \mathrm{C}$ in acetone to provide an indication of the wax purity. This yislded $75 \%$ de-afled wax, but also 2\% THF insolubles (Table 9). The de-oiled wax has less than $1 \%$ aromatic protons (Table 9).

\section{Preparation For Run ALC-3}

A sample of each catalyst precursor which will be tested in Run ALC-2 was requested from UKJCAER. The sample will be used to test methods to integrate catalyst addition during oil agglomeration in Run ALC-3. Summaries of the calalyst addition techniques used by CAER, including those used in Run ALC-2, were requested.

\section{Task 3 - Continuous Operations}

CONSOL reviewed and commented on the dratts of the ALC-2 run plan. CONSOL reviewed and epproved the HTI draft flowsheet for the continuous vacuum and atmospheric distillation and batch solids extraction systems for Run Al_C-2. G. Robbins met with E. Givens (UKVCAER) and T. Lee (HTI) to discuss issues related to the Run ALC-2 num plan, including: recycie solids concentration; catalyst type and concentration; the distillation system; addition of agglomeration or solvent hydrogenation to the run plan; and the potential advantage of adjusting the hydrogen feed rate if the space velocity is adjusted (i.e., fixing the ratio of hydrogen feed rate to MF coal feed rate). The run plan was discussed with M. Peluso (LDP Associates).

\section{Task 4 - Technical Assessment}

The CONSOL portion of the dratt quarterly Techrical Progress Report for January through March was revised as requested by DOE and resubmitted to UK. A report summarizing the Run ALC-1 post-run meefing at Lawrenceville, $\mathrm{NJ}$, on June 18 was issued to the project participants. CONSOL's comments on HTi's draft Run ALC-1 teport were discussed with T, Lee of HTI. 
The paper "Testing of Advanced Liquefaction Concepts in HTI Run ALC-1: Coal Cleaning and Recycle Solvent Treatment" was presented by G. A Robbins at the DOE First Joint Power and Fuel Systerns Contractors Conference and at the Thirteenth Annual international Pittsburgh Coal Conference. An electronic copy of the paper was sent to the Center for Conference Maragement, DOE's request Presentations were prepared on Runs ALC-1 and ALC-3 for the planning meeting in early October.

R. A. Winsehel

Project Manager

As 


\section{TABLE 1}

COMPOSITION OF SOH WATER PRODUCTS FROM HTI RUN ALC-1

\begin{tabular}{|c|c|c|c|c|c|}
\hline \multicolumn{2}{|c|}{ SOH Water Somple Source } & \multirow[b]{2}{*}{ pH } & \multicolumn{3}{|c|}{ Elemental Composition, wt \% of Sample } \\
\hline Perlod & Stage & & 8 (a) & N (b) & $\mathrm{C}$ (b) \\
\hline $6 \mathrm{~B}$ & First & $\underline{9.22}$ & 0.79 & 1.52 & 1.72 \\
\hline $\begin{array}{l}138 \\
138 \\
\end{array}$ & $\begin{array}{c}\text { First } \\
\text { Second }\end{array}$ & $\begin{array}{l}9.07 \\
9.74 \\
\end{array}$ & $\begin{array}{l}1.24 \\
2.69 \\
\end{array}$ & $\begin{array}{l}1.77 \\
2.14 \\
\end{array}$ & $\begin{array}{r}1.84 \\
0.54 \\
\end{array}$ \\
\hline $\begin{array}{l}17 \mathrm{~B} \\
17 \mathrm{~B}\end{array}$ & $\begin{array}{l}\text { First } \\
\text { Second }\end{array}$ & $\begin{array}{l}9.19 \\
9.21\end{array}$ & $\begin{array}{l}1.07 \\
2.50\end{array}$ & $\begin{array}{l}1.43 \\
2.00 \\
\end{array}$ & $\begin{array}{l}1.69 \\
0.27\end{array}$ \\
\hline $\begin{array}{l}20 \mathrm{~B} \\
20 \mathrm{~B}\end{array}$ & $\begin{array}{c}\text { First } \\
\text { Second }\end{array}$ & $\begin{array}{l}9.02 \\
9.29 \\
\end{array}$ & $\begin{array}{l}1.05 \\
2.52 \\
\end{array}$ & $\begin{array}{l}1.46 \\
1.85 \\
\end{array}$ & $\begin{array}{l}1.70 \\
0.12 \\
\end{array}$ \\
\hline $\begin{array}{l}258 \\
25 \mathrm{~B}\end{array}$ & $\begin{array}{l}\text { First } \\
\text { Second }\end{array}$ & $\begin{array}{l}8.94 \\
9.09\end{array}$ & $\begin{array}{l}0.66 \\
2.22\end{array}$ & $\begin{array}{l}1.25 \\
1.63\end{array}$ & $\begin{array}{l}1.71 \\
0.15\end{array}$ \\
\hline
\end{tabular}

(a) Tota! S anatysis by LECO SC-32 Sultur Anatyzer

(b) $\mathrm{C}$ and $\mathrm{N}$ analysts by $\mathrm{LECO} \mathrm{CHN}-1000$ Analyzer

TABLE 2

CONCENTRATION OF COMPONENTS OF THE FEED SLURRY SAMPLES FROM HTI RUN ALC-1

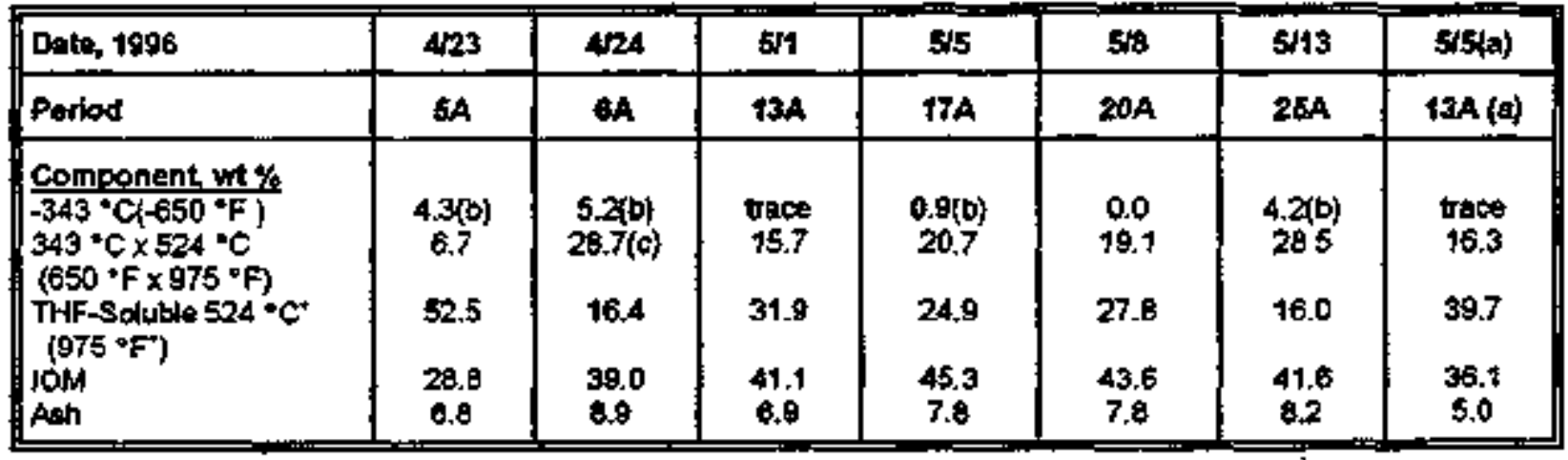

(a) Date/period in question

(b) May have contained an unknown amount of water

(c) End point was ca.529 ${ }^{\circ} \mathrm{C}\left(985^{\circ} \mathrm{F}\right)$, instead of $524^{\circ} \mathrm{C}\left(975^{\circ} \mathrm{F}\right)$

Actual distillation condritions were 5 tom/348 ${ }^{\circ} \mathrm{F}$ pot/378 ${ }^{\circ} \mathrm{F}$ head $\left(176^{\circ} \mathrm{C}\right.$ pot $192^{\circ} \mathrm{C}$ head) and 5 tom $/ 608^{\circ} \mathrm{F}$ pot $638^{\circ} \mathrm{F}$ head $\left(320^{\circ} \mathrm{C}\right.$ pot $337^{\circ} \mathrm{C}$ head) to provide effective cut points of $343^{\circ} \mathrm{C}$ $\left(650^{\circ} \mathrm{F}\right)$ and $524^{\circ} \mathrm{C}\left(975^{\circ} \mathrm{F}\right)$. 
TABLE 3

ASH ELEMENTAL COMPOSITION OF PRESSURE-FHTER CAKES

FRON HTI RUN ALC-1

\begin{tabular}{|c|c|c|c|c|c|}
\hline & 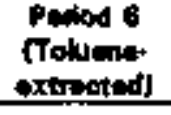 & $\begin{array}{c}\text { Pwiod } 13 \\
\text { (Ulnoxtractedi] }\end{array}$ & $\begin{array}{c}\text { Poilod } 17 \\
\text { Unextractod! }\end{array}$ & $\begin{array}{c}\text { Pariod } 20 \\
\text { (Unuxtropted }\end{array}$ & $\begin{array}{c}\text { Pexiad } 25 \\
\text { Alinextrogtedi }\end{array}$ \\
\hline 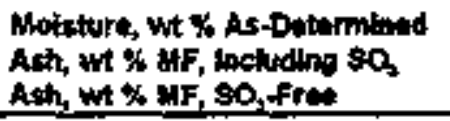 & $\begin{array}{r}0.50 \\
70.45 \\
51.58 \\
\end{array}$ & $\begin{array}{r}0.20 \\
47.49 \\
42.60 \\
\end{array}$ & $\begin{array}{r}0.31 \\
45.24 \\
40.58 \\
\end{array}$ & $\begin{array}{r}0.43 \\
46.61 \\
41.19 \\
\end{array}$ & $\begin{array}{r}0.41 \\
45,20 \\
31.64 \\
\end{array}$ \\
\hline 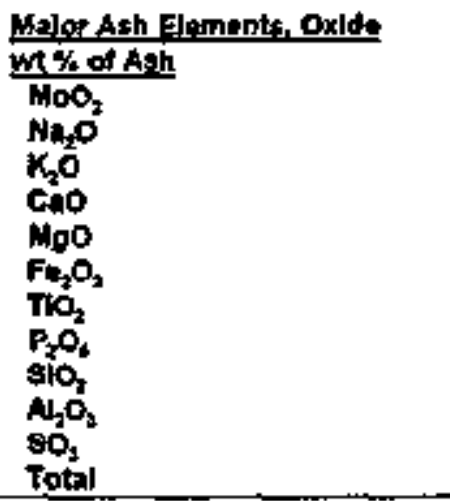 & $\begin{array}{r}0.21 \\
1.17 \\
0.29 \\
14.76 \\
3.29 \\
22.27 \\
0.77 \\
0.81 \\
10.05 \\
10.34 \\
25.76 \\
89.72\end{array}$ & $\begin{array}{r}0.31 \\
0.37 \\
0.33 \\
6.47 \\
1.14 \\
38.00 \\
1.42 \\
1.18 \\
27.76 \\
16.11 \\
10.29 \\
100.38\end{array}$ & $\begin{array}{r}0.49 \\
0.37 \\
0.41 \\
6.86 \\
1.14 \\
30.45 \\
1.68 \\
1.33 \\
50.60 \\
16.76 \\
10.31 \\
100.30\end{array}$ & $\begin{array}{r}0.56 \\
0.32 \\
0.37 \\
6.52 \\
1.02 \\
28.83 \\
1.61 \\
1.33 \\
3205 \\
17.97 \\
0.68 \\
58.30\end{array}$ & $\begin{array}{r}0.21 \\
1.17 \\
0.27 \\
17.45 \\
2.68 \\
17.94 \\
1.02 \\
1.00 \\
15.24 \\
11.66 \\
29.89 \\
99.42\end{array}$ \\
\hline 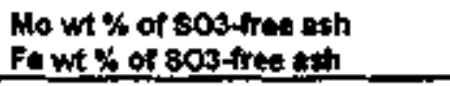 & $\begin{array}{r}0.22 \\
\mathbf{2 1 2 7} \\
\end{array}$ & $\begin{array}{r}0.26 \\
28.07 \\
\end{array}$ & $\begin{array}{r}0.41 \\
23.75 \\
\end{array}$ & $\begin{array}{r}0.47 \\
20.85 \\
\end{array}$ & $\begin{array}{r}0.23 \\
17.92 \\
\end{array}$ \\
\hline $\begin{array}{l}\text { Mo wt \% of s03-containing esh } \\
\text { Fe wt \% of } 803 \text {-oontalning ech }\end{array}$ & $\begin{array}{r}0.16 \\
15,68 \\
\end{array}$ & $\begin{array}{r}0.23 \\
25.18\end{array}$ & $\begin{array}{r}0.37 \\
21.30 \\
\end{array}$ & $\begin{array}{r}0.42 \\
18.84\end{array}$ & $\begin{array}{r}0.16 \\
12.55 \\
\end{array}$ \\
\hline \multicolumn{6}{|c|}{ HTI Analyses, wt \% of ASTM Ash (e) } \\
\hline 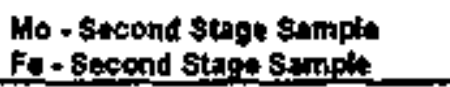 & $\begin{array}{l}0.195 \\
9.226\end{array}$ & $\begin{array}{c}0,202 \\
21,008 \\
\end{array}$ & $\begin{array}{l}0.400 \\
18.766 \\
\end{array}$ & $\begin{array}{r}0.403 \\
17.372 \\
\end{array}$ & $\begin{array}{c}0.160 \\
13.206 \\
\end{array}$ \\
\hline $\begin{array}{l}\text { Wo - First stage sample } \\
\text { Fe - First Stipe sample }\end{array}$ & $\begin{array}{c}0.198 \\
13.316\end{array}$ & $\begin{array}{r}0.168 \\
17,458\end{array}$ & $\begin{array}{r}0.218 \\
12.721\end{array}$ & $\begin{array}{r}0.232 \\
12202\end{array}$ & $\begin{array}{r}0.162 \\
10.708\end{array}$ \\
\hline
\end{tabular}

(a) Source: Table 16 (page 40) of the HTI draft Run ALC-1 report of June 1996. 
TABRE 4

ASH ELEMENTAL COMPOSITION OF FEED SLURRY $975^{\circ}{ }^{\circ}+$ RESIDS FROM HTI RUN ALC-?

\begin{tabular}{|c|c|c|c|c|c|c|}
\hline & Pertod 8 & Perlod 6 & Pertod 13 & Pirlod i7 & Purtod 20 & $\begin{array}{l}\text { Parfod } 25 \\
\text { (a) }\end{array}$ \\
\hline 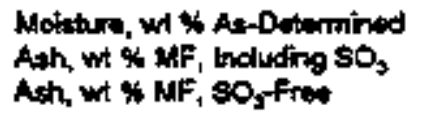 & $\begin{array}{l}0.26 \\
0.12 \\
6.00\end{array}$ & $\begin{array}{r}214 \\
1526 \\
11.42\end{array}$ & $\begin{array}{r}1.49 \\
10.29 \\
9.27\end{array}$ & $\begin{array}{r}1.25 \\
10.18 \\
9.25\end{array}$ & $\begin{array}{r}0.98 \\
10.02 \\
9.16\end{array}$ & $\begin{array}{r}2.16 \\
13.20 \\
9.90\end{array}$ \\
\hline 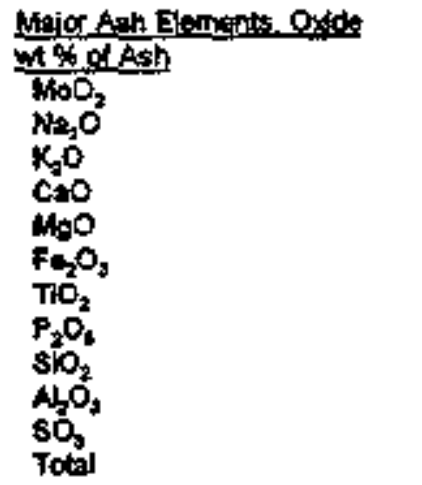 & $\begin{array}{r}0.20 \\
1.75 \\
0.29 \\
14.53 \\
3.46 \\
2.17 \\
0.79 \\
0.00 \\
10.70 \\
10.73 \\
25.41 \\
99.95\end{array}$ & $\begin{array}{r}0.20 \\
1.17 \\
0.29 \\
14.41 \\
3.18 \\
29.84 \\
0.70 \\
0.02 \\
19.00 \\
11.04 \\
20.16 \\
09.77\end{array}$ & $\begin{array}{r}0.43 \\
0.43 \\
0.43 \\
6.80 \\
1.25 \\
3.60 \\
1.41 \\
1.10 \\
26.28 \\
15.84 \\
9.80 \\
0.64\end{array}$ & $\begin{array}{r}0.49 \\
0.39 \\
0.40 \\
6.57 \\
1.09 \\
30.29 \\
1.59 \\
1.31 \\
30.82 \\
17.34 \\
0.03 \\
99.49\end{array}$ & $\begin{array}{r}0.56 \\
0.35 \\
0.36 \\
6.14 \\
0.88 \\
2.37 \\
1.67 \\
1.27 \\
31.64 \\
17.74 \\
8.60 \\
0.54\end{array}$ & $\begin{array}{r}0.20 \\
1.18 \\
0.28 \\
16.44 \\
3.43 \\
10.17 \\
1.02 \\
0.89 \\
19.03 \\
12.37 \\
5.01 \\
6.72\end{array}$ \\
\hline 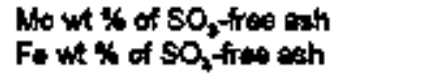 & $\begin{array}{r}0.20 \\
21.69\end{array}$ & $\begin{array}{r}0200 \\
200\end{array}$ & $\begin{array}{r}0.35 \\
26.11\end{array}$ & $\begin{array}{r}0.40 \\
23.29\end{array}$ & $\begin{aligned} 0.45 \\
\mathbf{2 2 . 4 7}\end{aligned}$ & $\begin{array}{r}0.20 \\
87.88\end{array}$ \\
\hline 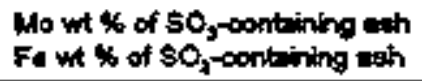 & $\begin{array}{r}0.16 \\
16.18\end{array}$ & $\begin{array}{r}0.15 \\
16.53\end{array}$ & $\begin{array}{r}0.32 \\
23.52\end{array}$ & $\begin{array}{r}0.35 \\
21.19\end{array}$ & $\begin{array}{r}0.42 \\
\mathbf{2 0 . 5 4}\end{array}$ & $\begin{array}{r}0.14 \\
13.41\end{array}$ \\
\hline
\end{tabular}

(a) Single detemingtion, others are averages of duplicate deteminations. 
TABLE 5

MO AND FE BALANCE AND APPARENT ADDITION RATES FOR HTI RUNN ALC-1

\begin{tabular}{|c|c|c|c|c|c|c|c|c|}
\hline \multicolumn{9}{|c|}{ TOTAL Mo \& Fe ho Feed Slutry, (Bassd on coal ash and recycte lOMtash rates): } \\
\hline Pentod & $\begin{array}{l}\text { MF cogal } \\
\text { in, } \mathbf{g}\end{array}$ & $\mathrm{Fe}_{2} \mathrm{O}_{3}$ & $\begin{array}{c}\text { Coal } \\
\text { Ashin in, } 9\end{array}$ & $\begin{array}{c}\text { Coal + Cat } \\
\text { Ash in, g }\end{array}$ & $\begin{array}{l}\text { Recycte } \\
\text { Ash ln, }\end{array}$ & $\begin{array}{l}\text { Total Ash } \\
\text { in, } 8\end{array}$ & $\begin{array}{c}\text { Totai Mo } \\
\text { in, } g\end{array}$ & $\begin{array}{l}\text { Total Fe } \\
\text { In, } \theta\end{array}$ \\
\hline 6 & 32,405 & 754 & 1,782 & 2,236 & 7,439 & 6,675 & 13.35 & 1,475 \\
\hline 13 & 26,760 & 375 & 884 & 1,259 & 3,535 & 4,795 & 17,26 & 1,252 \\
\hline 17 & 26,365 & 258 & 870 & $t, 128$ & 3,691 & 4,820 & Tड.28 & 7,72 \\
\hline 20 & 20,078 & 197 & 663 & 859 & 2,570 & 3,429 & 15.77 & 771 \\
\hline $\mathbf{5}$ & 22,362 & 219 & 1,230 & 1,448 & 2,303 & 3,752 & 7.50 & 671 \\
\hline \multicolumn{9}{|c|}{ MO F F In TOTALPFC OUT: } \\
\hline Pesiod & $\begin{array}{l}\text { Tot. PFC } \\
\text { Out, } 9\end{array}$ & $\begin{array}{l}\text { PFCAsh } \\
\text { Out, } g\end{array}$ & $\begin{array}{l}\text { PFCMo } \\
\text { Outig }\end{array}$ & $\begin{array}{l}\text { PFC Fe } \\
\text { Out, } 8\end{array}$ & $\begin{array}{c}\text { Mo outin, } \\
\text { Ratio }\end{array}$ & Fe Outhn, & & \\
\hline 5 & 13,275 & 6,816 & 15.00 & $-1,450$ & 7.12 & 0.98 & & \\
\hline 73 & 12,537 & 5,341 & T3.85 & 1,499 & 0.80 & 120 & & \\
\hline 17 & 71,775 & 4,778 & $\mathbf{T} .59$ & 7,135 & 1.02 & T.01 & & \\
\hline 20 & 8,919 & 3,674 & 17.27 & 766 & 7.09 & 0,59 & & \\
\hline 25 & 12,307 & 3,894 & 8.96 & 698 & 1.19 & 1,04 & & \\
\hline \multicolumn{9}{|c|}{ Ho \& Fe from RECYCLE PFC: } \\
\hline Period & $\begin{array}{l}\text { PFC } \\
\text { Recycie.g }\end{array}$ & $\begin{array}{l}\text { PrC Ash } \\
\text { Recycte. g }\end{array}$ & $\begin{array}{c}\text { PFC Mo } \\
\text { Recycle, g }\end{array}$ & $\begin{array}{c}\text { PFC Fé } \\
\text { Recycle, }\end{array}$ & $\begin{array}{l}\text { Mo Rechn. } \\
\text { Ratio }\end{array}$ & $\begin{array}{c}F_{e} \\
\text { Recilnt, }\end{array}$ & & \\
\hline 5 & 6,638 & 4,455 & 8.80 & \$48 & 0.73 & 0.64 & & \\
\hline$\sqrt{3}$ & 8,084 & 3,870 & 70.08 & T,086 & 0.68 & 0.87 & & \\
\hline 17 & 9,0830 & 3,654 & 75.02 & 870 & 0.78 & 0.78 & & \\
\hline 20 & 6,618 & 2,726 & $\sqrt{2.81}$ & 568 & 0.81 & 0.74 & & \\
\hline 25 & 7,420 & 2,348 & 5.40 & 421 & 0.72 & 0.63 & & \\
\hline \multicolumn{9}{|c|}{ Mo \& Fe NET in Frosh Feed: } \\
\hline Period & $\begin{array}{c}\text { Total Mo } \\
\ln , 9\end{array}$ & $\begin{array}{l}\text { Total Fe } \\
\ln .0\end{array}$ & $\begin{array}{l}\text { PFC Mo } \\
\text { Recycle, } g\end{array}$ & PFC Fe & $\underset{\text { Fresh Mo }}{\text { Calc }_{\text {in }}}$ & $\begin{array}{c}\text { Calc } \\
\text { Fresh Fe } \\
\text { In, o }\end{array}$ & $\begin{array}{l}\text { Calc } \\
\text { Fresh Wo } \\
\text { Rate. }\end{array}$ & $\begin{array}{c}\text { Target } \\
\text { Mo Rate, } \\
\text { Pom }\end{array}$ \\
\hline 6 & $\sqrt{3.35}$ & 7,475 & 9.80 & 948 & 3.55 & 527 & 710 & 100 \\
\hline 13 & 77.25 & 1,252 & 10.65 & 3,086 & 7.20 & 16 & 269 & 100 \\
\hline 77 & 79.25 & $\sqrt{1,122}$ & 15.02 & 670 & 4.25 & 252 & 161 & 70 \\
\hline 20 & 15.77 & 771 & 12.81 & 568 & 2.96 & 202 & 148 & 70 \\
\hline 25 & 7.50 & 671 & 5.40 & 421 & 2.11 & 250 & 94 & 70 \\
\hline Period & $\begin{array}{c}\text { Catc Fe } \\
\text { Total Rate, } \\
\text { Ppm }\end{array}$ & $\begin{array}{l}\text { Fe from } \\
\text { Coal, ppon }\end{array}$ & $\begin{array}{l}\text { Calc. Fresh } \\
\text { Added Fe } \\
\text { Rate, ppm }\end{array}$ & $\begin{array}{c}\text { Target } \\
\text { Added Fe } \\
\text { Rate, ppm }\end{array}$ & & & & \\
\hline 6 & 16,267 & 2,618 & 13,642 & 10,000 & & & & \\
\hline 13 & 6.184 & 2,256 & 3,928 & 10,000 & & & & \\
\hline 57 & 8,565 & 2,258 & 7,300 & 7,000 & & & & \\
\hline 20 & 10,073 & 2,256 & 7,815 & 7,000 & & & & \\
\hline 25 & 11,189 & 2,618 & 8,571 & 7,000 & & & & \\
\hline
\end{tabular}

A. ppm values are on a ppm (mg/kg) MF coal basis. 
TABLE 6

WAX CONTENT IN VSOH

RUN ALC-1

\begin{tabular}{||l|c|c|c|c|}
\hline \multirow{2}{*}{ Stream } & & \multicolumn{3}{|c|}{ Wax Yeld at Temperature (a), \% } \\
\cline { 3 - 5 } & Period & $-5 \cdot \mathrm{C}$ & $-20{ }^{\circ} \mathrm{C}$ & $-\mathbf{3 5}{ }^{\circ} \mathrm{C}$ \\
\hline O-6 Bottoms Distillate & 20 & 5.2 & 5.9 & 6.1 \\
VSOH & 25 & 1.2 & 1.5 & 26 \\
VSOH, dewaxed & 25 & 0.1 & 0.1 & 0.2 \\
\hline
\end{tabular}

(a) Yieid of wax obtained in laboratory dewaxing test with acetone at the specified temperature. 
TABLE 7

NWR ANALYSES AND MICROAUTOCLAVE TESTS RELLEANT TO RUN ALC-1 DEWAXING OPERATIONS

\begin{tabular}{|c|c|c|c|c|c|c|c|c|c|c|}
\hline & \multirow[b]{2}{*}{ Perlod } & \multicolumn{7}{|c|}{ Proton Distribution $\times$} & \multicolumn{2}{|c|}{$\begin{array}{l}\text { Mirtomitoctave Coal } \\
\text { Conversion, wt * MAF }\end{array}$} \\
\hline & & $\begin{array}{l}\text { Cond } \\
\text { Arom }\end{array}$ & $\begin{array}{l}\text { Unoond } \\
\text { Arom }\end{array}$ & $\begin{array}{l}\text { Cyollo } \\
\text { Alpha }\end{array}$ & $\begin{array}{l}\text { Alky } \\
\text { Alphra }\end{array}$ & $\begin{array}{l}\text { Crailic } \\
\text { Beta }\end{array}$ & $\begin{array}{l}\text { Alkyl } \\
\text { Batt }\end{array}$ & Canra & $\begin{array}{l}\text { Test A } \\
\text { (a) }\end{array}$ & $\begin{array}{c}\text { Teat } \\
\text { (b) }\end{array}$ \\
\hline 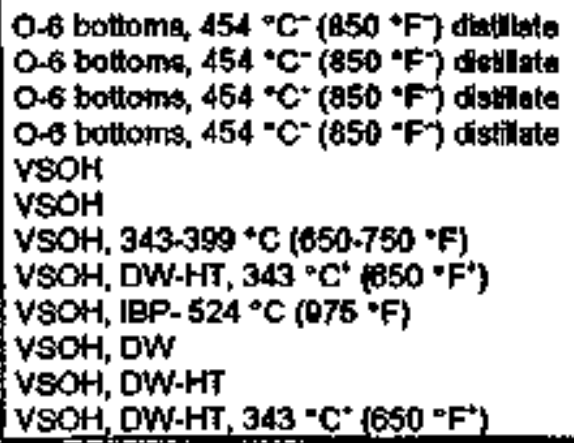 & $\begin{array}{l}13 \\
17 \\
20 \\
25 \\
13 \\
17 \\
20 \\
214 \\
25 \\
25 \\
25 \\
25 \\
\end{array}$ & $\begin{array}{r}15.8 \\
15.4 \\
16.0 \\
14.3 \\
12.3 \\
13.1 \\
15.3 \\
9.0 \\
17.8 \\
17.8 \\
8.2 \\
10.8\end{array}$ & $\begin{array}{r}9.9 \\
10.1 \\
10.0 \\
9.2 \\
10.5 \\
10.3 \\
6.6 \\
6.6 \\
6.2 \\
9.6 \\
6.1 \\
6.3\end{array}$ & $\begin{array}{l}15.6 \\
15.8 \\
16.2 \\
14.8 \\
15.5 \\
14.9 \\
16.3 \\
15.3 \\
17.8 \\
17.1 \\
15.8 \\
18.4\end{array}$ & $\begin{array}{l}11.1 \\
10.7 \\
11.2 \\
11.3 \\
12.5 \\
11.5 \\
10.8 \\
10.5 \\
11.0 \\
11.3 \\
0.0 \\
10.0\end{array}$ & $\begin{array}{l}12.6 \\
12.5 \\
12.6 \\
15.4 \\
14.1 \\
13.1 \\
12.9 \\
19.8 \\
15.7 \\
14.5 \\
21.4 \\
19.7\end{array}$ & $\begin{array}{l}23.6 \\
24.5 \\
23.3 \\
21.2 \\
23.9 \\
24.9 \\
26.9 \\
23.4 \\
20.8 \\
18.0 \\
23.1 \\
21.3\end{array}$ & $\begin{array}{l}10.8 \\
11.2 \\
t 0.5 \\
t 3.8 \\
11.1 \\
12.3 \\
t 0.2 \\
15.3 \\
10.6 \\
t 1.5 \\
15.5 \\
13.0 \\
\end{array}$ & $\begin{array}{c}88.1 \\
07.6 \\
86.7 \\
86.4 \\
: \\
: \\
92.7 \\
69.5 \\
69.7 \\
92.8 \\
94.4\end{array}$ & $\begin{array}{c}: \\
78.3 \\
79.4 \\
\dot{-} \\
\dot{-} \\
80.0 \\
82.3 \\
89.9 \\
90.5\end{array}$ \\
\hline
\end{tabular}

(a) Modified equlibrium tes, Odd Ben Mine ood

(b) Btack Thundar Mine cot (4.55 g), solvent $(5.45 \mathrm{~g}), 30 \mathrm{~min}, 440^{\circ} \mathrm{C}\left(624^{\circ} \mathrm{F}\right), 10.3 \mathrm{MPa}(1500 \mathrm{psig}) \mathrm{H}_{2}$ (cold) 


\section{TABLE 8}

\section{SUMBMARY OF H-NMR ANALYSES AND MICROALTOCLAVE TESTS RELEVANT TO ALC-1 DEWAXING OPERATIONS}

\begin{tabular}{|c|c|c|c|c|c|c|}
\hline \multirow[b]{2}{*}{ Partiod } & \multirow[b]{2}{*}{ sireal } & \multicolumn{3}{|c|}{ M-Amar Proton Types, } & \multicolumn{2}{|c|}{$\begin{array}{l}\text { Microsurtockave Coal } \\
\text { Conversion } \$ \text { MAf }\end{array}$} \\
\hline & & Aromitis & cxatis & Putinis & $\begin{array}{c}\text { Tost A } \\
\text { (a) }\end{array}$ & Toest $B$ \\
\hline $\begin{array}{l}\$ 3.17 .20 \\
25 \\
75 \\
25 \\
25\end{array}$ & 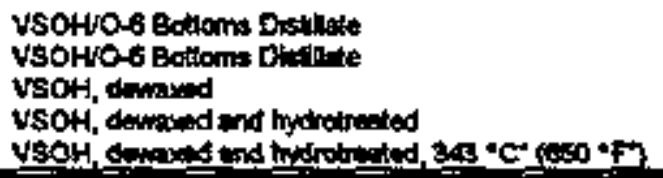 & $\begin{array}{l}24.5 \pm 1.4 \\
237 \pm 0.3 \\
27.0 \\
14.3 \\
17.1\end{array}$ & $\begin{array}{l}26.7 \pm 06 \\
31.6 \pm 1.7 \\
31.6 \\
37.2 \\
32.1\end{array}$ & $\begin{array}{l}55.4 \pm 1.2 \\
3 \times .4 \pm 1.4 \\
29.5 \\
39.6 \\
34.3\end{array}$ & $\begin{array}{l}67.4 \pm 0.7 \\
00.0 \pm 08 \\
89.7 \\
92.6 \\
94.4\end{array}$ & $\begin{array}{l}70.3 \\
79.400 .9 \\
62.3 \\
69.9 \\
9.5\end{array}$ \\
\hline
\end{tabular}

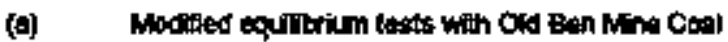

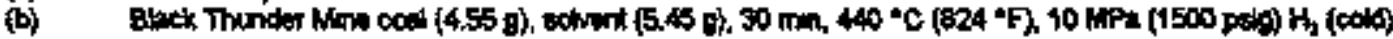


TABLE 9

ANALYSIS AND DE-OILNG YIELDS OF WAX FROM RUN ALC-1, Period 25

\begin{tabular}{|l|c|}
\hline & wt $\%(b)$ \\
\hline Elemental Anabosis of Original & \\
\hline Wax & $73.82(\mathrm{~b})$ \\
$\mathrm{H}$ & 13.70 \\
$\mathrm{~N}$ & 0.20 \\
$\mathrm{~S}$ & 0.06 \\
\hline
\end{tabular}

(a) Averege of four determinations. Repeatability was ca. $\pm 5 \%$ relative.

(b) Suspect low, ef. text.

\begin{tabular}{|c|c|}
\hline \multicolumn{2}{|c|}{ Yolds from Do-Oiling Otiging: Wax } \\
\hline Fractlon & wt $\%$ \\
\hline $\begin{array}{l}\text { De-Oiled Wox } \\
\text { Oll } \\
\text { Insolubles } \\
\text { Lossas }\end{array}$ & $\begin{array}{r}74.7 \\
19.4 \\
1.7 \\
4.2\end{array}$ \\
\hline
\end{tabular}

\begin{tabular}{|c|c|c|c|c|c|c|c|}
\hline \multicolumn{8}{|c|}{ Proton Distributione of De-Oiling Fractions } \\
\hline & \multicolumn{7}{|c|}{ Proton Distribution. \% } \\
\hline & $\begin{array}{l}\text { Cond } \\
\text { Arom }\end{array}$ & $\begin{array}{l}\text { Uncond } \\
\text { Arom }\end{array}$ & $\begin{array}{l}\text { CycFic } \\
\text { Alpha }\end{array}$ & $\begin{array}{l}\text { Alkyt } \\
\text { Alpha }\end{array}$ & $\begin{array}{l}\text { Cyelic } \\
\text { Beta }\end{array}$ & $\begin{array}{l}\text { Allky } \\
\text { Beta }\end{array}$ & Gamma \\
\hline $\begin{array}{l}\text { Ofiginal Wax } \\
\text { Do-Oiled Wax } \\
\text { OH }\end{array}$ & $\begin{array}{l}2.5 \\
0.5 \\
8.9 \\
\end{array}$ & $\begin{array}{l}1.4 \\
0.2 \\
3.3 \\
\end{array}$ & $\begin{array}{l}4.6 \\
0.6 \\
8.5 \\
\end{array}$ & $\begin{array}{l}3.2 \\
0.7 \\
5.5 \\
\end{array}$ & $\begin{array}{r}8.1 \\
3.3 \\
t 0.6 \\
\end{array}$ & $\begin{array}{l}68.7 \\
80.4 \\
49.9 \\
\end{array}$ & $\begin{array}{l}11.5 \\
14.4 \\
13.3 \\
\end{array}$ \\
\hline
\end{tabular}

